\title{
TEPLOVZDUŠNÉ VYKUROVANIE V STREDOVEKU NA ÚZEMÍ SLOVENSKA
}

\author{
M A R T I N H A N U Š
}

\begin{abstract}
Hot air heating in the Middle Ages in Slovakia. The study deals with the issue of medieval hot air heating furnaces, also referred to as hypocaustum, in the territory of Slovakia. The paper offers an overview of research, brings a catalog of furnaces from Slovakia and their documentation, while critically evaluating older findings and publishing new hitherto unknown specimens. At the end the study analyzes the common features of furnaces and examine also their broader architectural and social context. The study fills in the blanks on the distribution map of this technology and chronologically specifies the process of its spreading and marginalization.
\end{abstract}

Keywords: Slovakia, Middle Ages, air heating, hypocaust, housing culture.

\section{ÚVOD}

Ochrana pred chladom či zimou bola a stále zostáva jednou zo základných výziev pre ludstvo. Vykúrený obytný priestor zbavený dymu a splodín pritom predstavuje nesamozrejmý civilizačný výdobytok, ktorý sa stal všeobecným štandardom len v relatívne nedávnej dobe. Cielom predkladanej práce je systematické spracovanie problematiky špecifického stredovekého spôsobu vykurovania pomocou teplého vzduchu.

Táto technológia sa sformovala v 10. stor. na základe antických tradícií v strednom Nemecku a postupne sa rozšírila na rozsiahlom území strednej a severnej Európy. Stredoveké teplovzdušné pece, nazývané aj hypocaustum, ${ }^{1}$ fungovali primárne na princípe prúdenia tepla (konvekcie) v plynných látkach. Tento princíp umožňoval rýchle ohriatie aj vel'kých priestorov, vd’aka teplému vzduchu stúpajúcemu z rozohriatých pecí situovaných pod podlahou, smerom nahor do obytných miestností. Na rozdiel od rímskych hypokaust, ohrievajúcich podlahu, prípadne steny stavieb a využívajúcich ako primárny vykurovací princíp vedenie tepla v pevnej látke (kondukciu), vpúštali stredoveké zariadenia ohriaty vzduch zbavený dymu priamo do miestnosti.

V predloženej práci sa zameriavame na územie Slovenska, kde nebola problematika dosial' systema- ticky spracovaná, ${ }^{2}$ pričom pracujeme s európskym kontextom fenoménu, ktorý bol dôležitou súčastou kultúry bývania stredovekých elít.

\section{METÓDA PRÁCE}

V prvom kroku sme zostavili katalóg hypokaust, ktorý je koncipovaný formou ucelených textov, nakol'ko bolo potrebné uchopit nálezy komplexne $\mathrm{v}$ širších nálezových súvislostiach. Ide zväčša o dosial' nepublikovaný materiál, resp. zverejnený len v menšom rozsahu, ktorý si niekedy vyžadoval prehodnotenie. Údaje v katalógu obsahujú okrem opisu, analýzy a datovania zariadenia aj širší stavebno-historický a sociálny kontext stavby, pričom pozornost' sme venovali aj prítomnosti d’alších súdobých vykurovacích telies v objekte, predovšetkým kachlovým peciam.

Pri typologickej identifikácií zariadení sme vychádzali z konštrukčných prvkov s diagnostickým potenciálom. Niekedy sme sa však mohli opriet' len o pomocné indície, ako napr. datovanie objektu, čo umožnilo vylúčit chronologicky staršie typy pecí a pod. Ponúkali sa pritom viaceré typologické návrhy (napr. Buśko 1995; Hauserová 2003; 2015; Konečný 1983; Meyer 1989). V našej štúdii pracujeme s triedením K. Bingenheimera (1998) vypracovaným na základe najväčšieho súboru dát. Jeho návrh

\footnotetext{
1 Niektorí bádatelia, najmä z Nemecka (Bingenheimer 1998, 4 n.; Meyer 2001, 2 n.), vymedzujú pre stredoveké systémy len pomenovanie Luftheizung (príp. Warmluftheizung, Heissluftheizung), teda teplovzdušné kúrenie vyjadrujúce odlišný vykurovací princíp - konvekciu, pri ktorom je primárnym nosičom tepla vzduch. My sa domnievame, že je prípustné paralelné používanie obidvoch termínov. V antickom období totiž evidujeme, aj ked’ len výnimočne, prípady hypokaust, ktoré vpúštali ohriaty vzduch aj priamo do miestnosti, čo vo svojej práci dokladá aj K. Bingenheimer (1998, 11-25, 195). Další argument vidíme vo fakte, že pojem hypocaustum bol známy a používaný v stredovekých, ako aj novovekých prameňoch (bližšie k problematike Hanuš 2016, 25 n.).

2 Štúdia je aktualizovanou častou dizertačnej práce autora (Hanuš 2016), ktorý skúmaný fenomén spracoval v juhovýchodnej časti strednej Európy (Slovensko, Česko, Rakúsko, Mad’arsko, Rumunsko).
} 

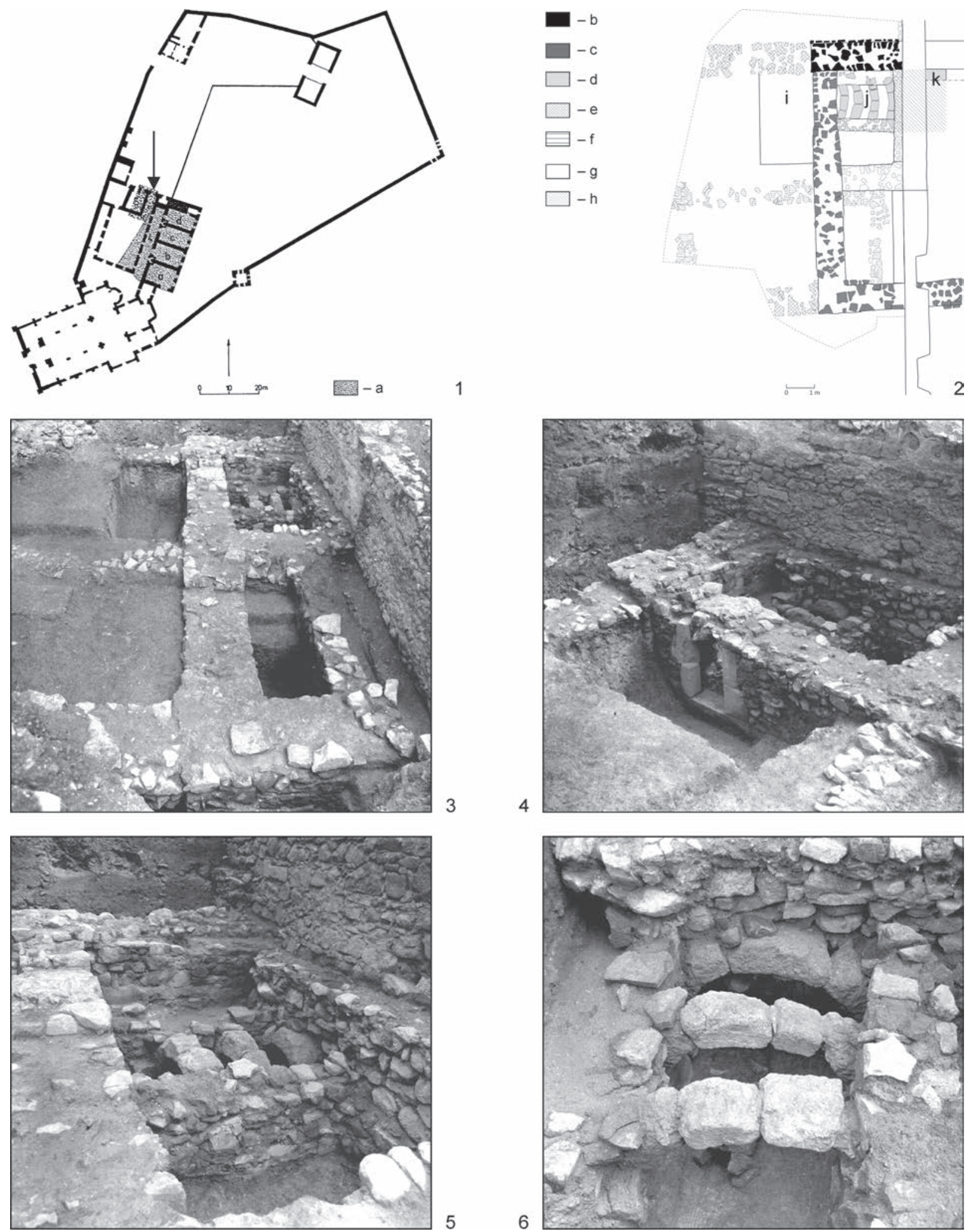

5

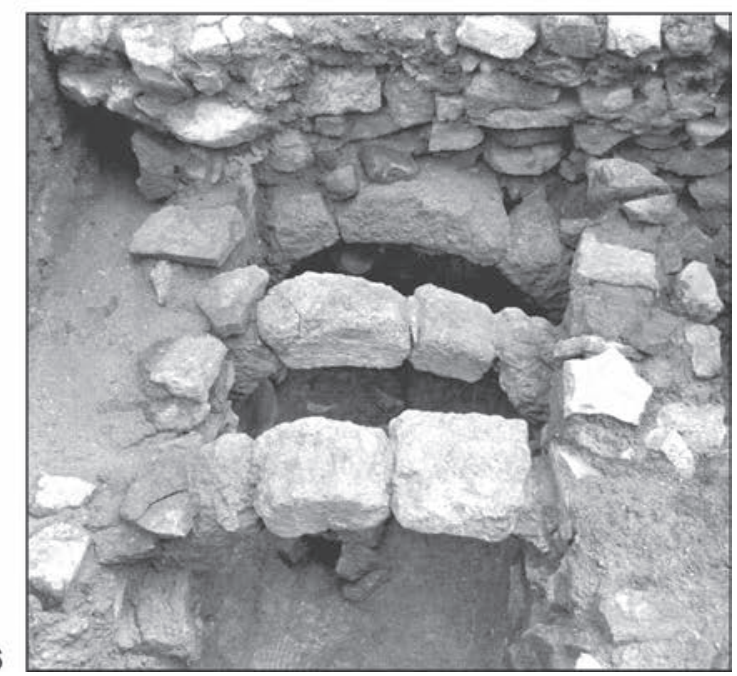

Obr. 1. Banská Štiavnica, kláštor dominikánov. 1 - pôdorys kláštora z polovice 18. stor. s vyznačenou polohou zariadenia; 2 - pôdorys severného krídla kláštora, detail s pecou (1, 2 podl’a Hanuliak 1996, stavebné fázy podla autora); 3 - západné ukončenie severného krídla kláštora s nálezom pece; 4 - obslužný priestor a vstup do pece; 5, 6 - detail na pec s roštom (3-6 podla Hanuliak 1994). Legenda: a - plocha výskumu v rokoch 1990-1994; b - 1. fáza, 1. etapa (štvrtá štvrtina 13.-prvá polovica 14. stor.); c - 1. fáza, 2. etapa; d - 1. fáza, 3. etapa (hypokaustum); e - 3. fáza (druhá polovica 14.-prvá polovica 15. stor.); f - neidentifikované; g - jezuitská stavebná fáza (18. stor.); h - predpokladaný rozsah hypokausta; i - obslužný priestor; j- pec; $\mathrm{k}$ - sonda $4 / 06$. 
kombinuje vykurovací princíp, konštrukčné riešenie a chronologický aspekt, $\mathrm{v}$ dôsledku čoho ponúka konzistentné evolučné triedenie, s ktorým sa stotožňujeme.

Katalóg obsahuje aj niektoré len potenciálne nálezy, ktoré nebolo možné spolahlivo potvrdit', avšak ani celkom vylúčite. Upozornenie na ne môže $\mathrm{v}$ budúcnosti viest' $\mathrm{k}$ d’alšiemu výskumu. Každý exemplár má priradené samostatné katalógové číslo, ktoré tvoria dve číslice. Prvá označuje lokalitu, druhá poradie pece $\mathrm{v}$ rámci nej. Z niektorých lokalít evidujeme len nálezy podlahových platní. Tie sme považovali za spolahlivý doklad prítomnosti technológie. V poslednej časti štúdia analyzuje spoločné konštrukčné charakteristiky identifikovaných exemplárov a pokúša sa načrtnút postup šírenia technológie, a zároveň zachytit priebeh jej marginalizácie, ako aj príčiny tohto procesu.

\section{DEJINY VÝSKUMU NA SLOVENSKU³}

Problematike teplovzdušných vykurovacích zariadení na území Slovenska zatial' nebola venovaná samostatná štúdia. Za najstarší objav hypokausta možno považovat nález z výskumu B. Pollu (1957) v Nemešanoch, stojaci na počiatkoch stredovekej archeológie na Slovensku, ktorú však autor interpretoval ako chlebovú pec. Ďalšie exempláre hypokaust sa začali objavovat' od 70. rokov s rozvojom výskumu stredovekých lokalít (Hronský Beňadik 1974, Košice-Krásna 1975, Spišské Podhradie-Pažica 1976, Beckov 1978), avšak pre nedostatočné poznatky o tomto technologickom fenoméne nad'alej unikali adekvátnej interpretácii. Istú pozornost’ tejto problematike venovali v krátkej stati až $M$. Slivka a A. Vallašek (1991, 67 n.). Okrem nálezov z benediktínskeho a dominikánskeho kláštora $v$ Košiciach (Polla 1986; Rusnák 2018) a benediktínskeho kláštora v Ludaniciach (Hanuš 2018), boli doposial' publiko- vané len formou stručnej zmienky objekty z Levoče (Javorský 1990, 81-84) a Spišskej Kapituly-Pažice (Vallašek 1999).

\section{KATALÓG}

\subsection{Banská Štiavnica, kláštor dominikánov}

Kláštor dominikánov v Banskej Štiavnici bol založený pravdepodobne po roku 1275, ked dominikáni získali do svojej držby starší, už stojaci Kostol sv. Mikuláša, pochádzajúci z 30. rokov 13. stor., od osady Štiavnica (Pomfyová 2018, 68-70, 92; Ragač 2006). ${ }^{4}$ Následne tu bol vybudovaný kláštor v troch, resp. štyroch dosial identifikovaných etapách (Gojdič/Paulusova 2010). ${ }^{5}$ Dominikáni zo Štiavnice odišli pod tlakom reformácie v roku 1536 (Jankovič 1965).

Areál kláštora bol z väčšej časti preskúmaný počas archeologického výskumu, ktorý prebiehal s prestávkami v rokoch 1990-1994 (obr. 1: 1; Hanuliak 1996; Hanuliak/Hoššol Hunka 1996). ${ }^{6}$ Nové poznatky a prehodnotenie niektorých záverov priniesol revízny výskum v roku 2006 (Hraškovál Hanuš/Miňo 2006) a následný stavebno-historický výskum, ktorý tieto závery potvrdil a dalej rozpracoval (Gojdičl Paulusová 2010).

Vykurovacie zariadenie sa nachádzalo $\mathrm{v}$ pravdepodobne najstaršej časti kláštora, v severnom krídle, ktoré tvorila jedna, možno dve miestnosti. ${ }^{7}$ Presnejšie ho môžeme lokalizovat do severozápadného nárožia potenciálnej západnej miestnosti s rozmermi 7,61 x 5,48 $\mathrm{m}\left(41,70 \mathrm{~m}^{2}\right){ }^{8}$ Vykurovacia komora bola situovaná v interiéri a vstupná šachta v exteriéri za západným obvodovým múrom. V dôsledku neskorších prestavieb, ktoré prebehli ešte v dominikánskom období, sa priestor vstupnej šachty stal súčastou interiéru predíženého severného krídla kláštora (obr. 1:2, 3). V postdominikánskom období vykurovaná miestnost̉ sčasti zanikla a sčasti bola prestavaná. ${ }^{9}$

Vykurovacia komora mala obdížnikový tvar s dochovaným vnútorným rozmerom 2,08 x 1,22 m (obr. 1: 2, 5, 6). Jej bočné steny boli vymurované z lomového kameňa a boli pristavané k severnej a západnej obvodovej stene miestnosti. Južná stena hypokausta bola hrubá $0,52 \mathrm{~m}$ a jej základ stupňovite klesal, takže výška múru bola 0,4-0,9 m. Severná stena bola hrubá $0,45 \mathrm{~m}$ a vysoká $0,6 \mathrm{~m}$ a niesla stopy po ohni. Do bočných stien bol osadený rošt pece (obr. 1: 6).

3 Pre krátkost’ miesta sa tu nemožno venovat dejinám výskumu v celoeurópskom kontexte (bližšie k tomu pozri Hanuš 2016, 14-17).

4 Podla starších názorov sa uvažovalo o založení kláštora pred tatárskym vpádom v 30. rokoch 13. stor. (Hanuliak/Hoššo/ Hunka 1996, 316 n.; Jankovič 1965, 127, 129). Revízny archeologický výskum v roku 2006 realizovaný M. Hanušom, M. Miňom a E. Hraškovou nepriniesol doklady, ktoré by uvedený predpoklad potvrdzovali.

5 1. etapa: ? (po 1275), 2. etapa: prvá polovica 14. stor., 3. etapa: druhá polovica 14. stor./prvá polovica 15. stor., 4. etapa: druhá polovica 15. stor. (stavebné články s letopočtami 1459, 1477)

6 Ďakujem Milanovi Hanuliakovi za poskytnutie výskumnej dokumentácie.

7 Odkryté bolo počas etapy v roku 1994.

8 Obvodové múry severného krídla vykazujú istú etapovitost' - konkrétne: južný múr je so západným previazaný len čiastočne a západný obvodový múr so severným nie je previazaný vôbec (obr. 1: 2). Napriek tomu konštrukciu západnej miestnosti možno s istotou vnímat’ ako jednu stavebnú fázu.

9 Pravdepodobne to súviselo s asanovaním východnej časti dominikánskej krížovej chodby a s výstavbou novej jezuitskej chodby pozdliž východného krídla kláštora v 18. stor. (Gojdič/Paulusová 2010, 299). Bývalý vykurovaný priestor potom sčasti slúžil ako priechod z rajského dvora do areálu, nachádzajúceho sa severne od kláštora (obr. 1: 1). 

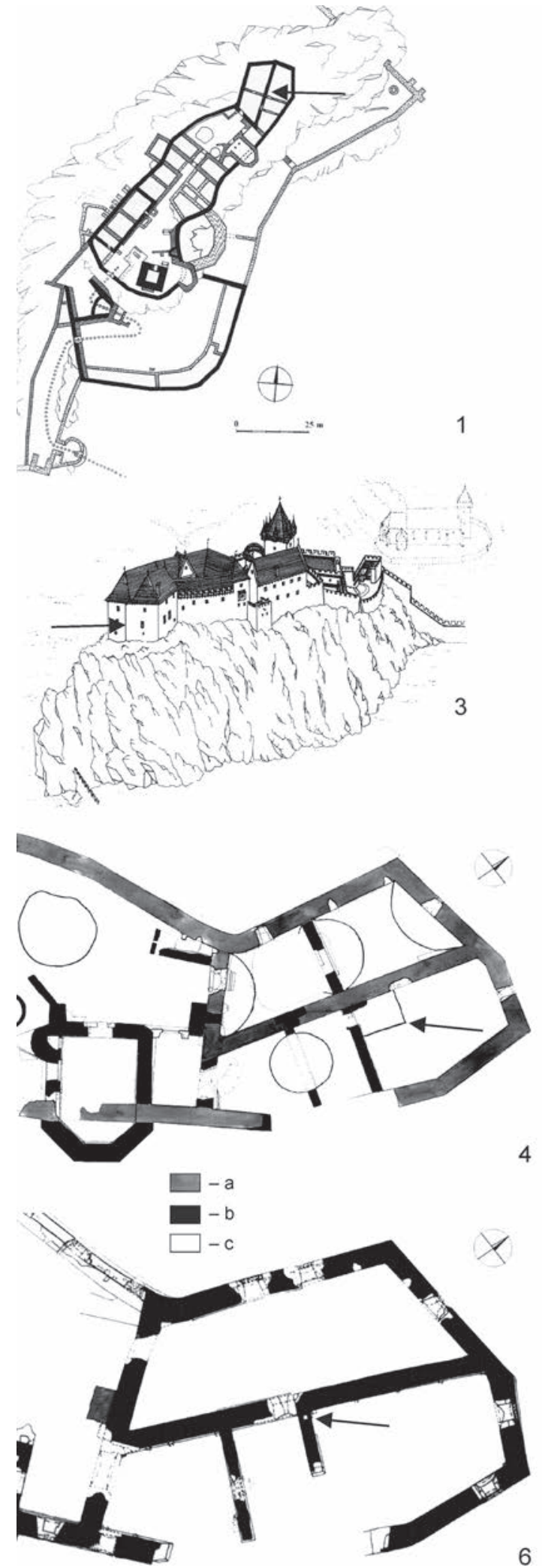
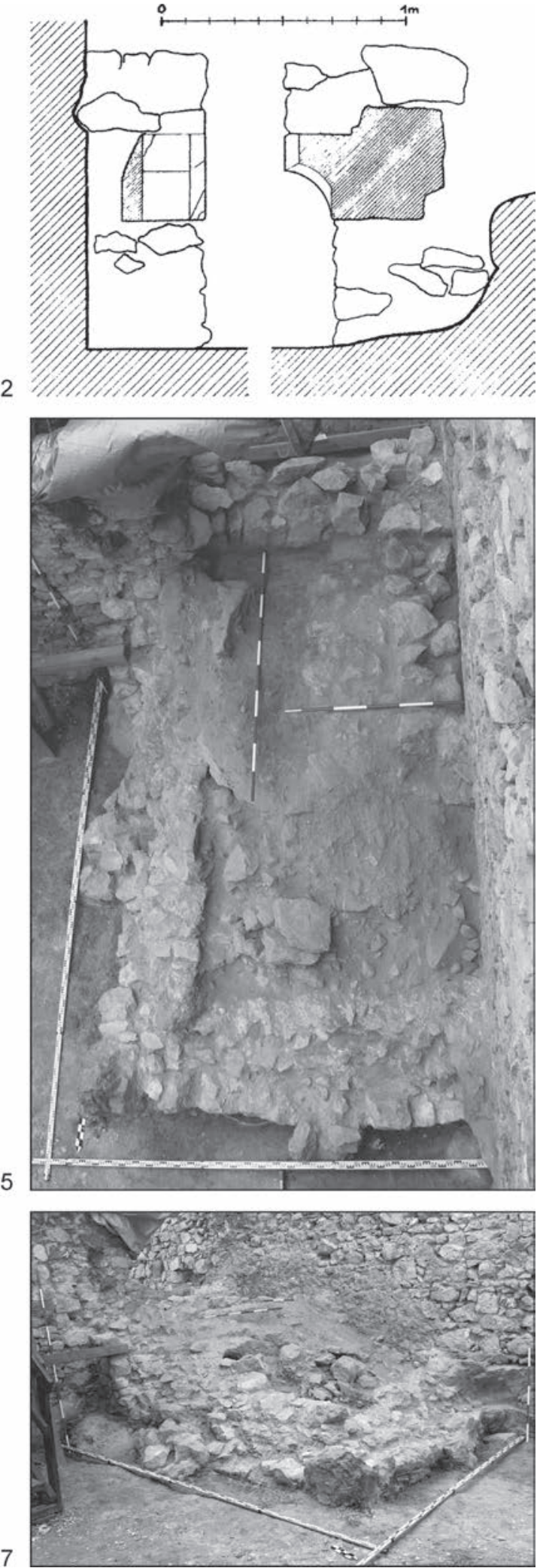

Obr. 2. Beckov, hrad, severný palác. 1 - pôdorys hradu s vyznačenou polohou pece; 2 - čelný a bočný pohl’ad na otvor do pece; 3 - ideálna rekonštrukcia hradu s vyznačenou polohou pece (1, 3 podla Plaček/Bóna 2007); 4 - pôdorys prízemia severného paláca s vyznačenou polohou pece (podla Tóthová 1978); 5 - pohl’ad z vrchu na pec; 6 - pôdorys prvého poschodia severného paláca s vyznačenou polohou dymovodu (2, 6 podla Jančušková 1971); 7 - pohlad na nárožie pece

(5, 7 podl’a Malec 2020). Legenda: a - polovica 13. stor.; b - 1388-1414 (Stibor starší); c - polovica 15. stor. 
Ten tvorili štyri klenbové pásy vyhotovené z troch až štyroch kamenných kvádrov z drolivého tufu, opracovaných do oblúkovitého tvaru. Rošt bol údajne prekrytý plochými dlaždicovými kameňmi (Hanuliak 1994, 4).

Západná - čelná stena pece bola zároveň západnou obvodovou stenou vykurovanej miestnosti (obr. 1: 4). To dokladá, že hypokaustum je súčasné s výstavbou miestnosti a spadá do najstaršej stavebnej fázy kláštora. Šírka múru bola $0,82 \mathrm{~m}$ a výška $1,25 \mathrm{~m}$. Vstup do pece zabezpečoval pomerne vel'ký portál s rozmermi 1,2 x 0,7 m (obr. 1: 4). Ostenie vstupu tvorili dva vel'ké opracované kvádre po oboch stranách (tri tmavočervenej a jeden sivej farby). Prah portálu vyhotovili z dvoch plochých kvádrov, na ktoré dosadalo ostenie portálu. Nadpražie portálu bolo vymurované z kameňov spájaných kvalitnou maltou.

Východná čast̉ pece bola deštruovaná počas výstavby barokovej chodby jezuitského gymnázia (obr. 1: 2). Príležitost’ pre jej rekonštrukciu sa naskytla počas revízneho výskumu v roku 2006. V sonde (4/06; obr. 1: 2: k) situovanej v priestore jezuitskej chodby sa nachádzala charakteristická, dočervena prepálená hlina, vyskytujúca sa $\mathrm{v}$ deštrukcii hypokaust. Vyskytli sa tu aj riečne okruhliaky, čierne od sadzí a pochádzajúce $z$ roštu pece. $V$ sonde sme pravdepodobne zachytili aj východné ukončenie severnej steny hypokausta (Hraškovál Hanuš/Miňo 2006, 11 n., výkres 3; 4). V prípade, že jej další priebeh nebol v minulosti rozobratý, možno celkovú vonkajšiu dížku vykurovacej komory rekonštruovat na 4,74 m.

Dno pece tvorila hlinitá podlaha, zahĺbená trochu hlbšie pod úroveň múrov komory..$^{10} \mathrm{Na}$ podlahe sa prekvapivo nachádzala malá, z kameňa murovaná, pravdepodobne sekundárna stavba vo forme kanála (obr. 1: 6). Domnievame sa, že mohla slúžit na odtok vody, ktorá sa tu koncentrovala. Takýto účel stavby potvrdzuje aj kanál vyhotovený z väčších plochých kameňov (15 x $15 \mathrm{~cm})$, situovaný v exteriéri pozdĺž severného múra vykurovanej miestnosti, ktorý prechádzal otvorom $v$ múre $(0,5 \times 0,4 \mathrm{~m})$ práve do priestoru pece. Objekt interpretujeme ako neskoršiu úpravu zariadenia, vykonanú po ukončení jeho vykurovacej funkcie.

Obslužný priestor pece tvorila len jednoduchá obdížnikovitá jama s rozmermi 3,21 x 1,89 m (obr. 1: 2, 4). Situovaná bola pozdíž západného obvodového múra vykurovanej miestnosti. Ako sme vyššie spomenuli, tento priestor pôvodne predstavoval exteriér. Po výstavbe krížovej chodby a po rozšírení severného krídla kláštora smerom na západ v druhej polovici 14., resp. prvej polovici 15. stor. (Gojdičl Paulusová 2010, 298) sa stal súčastou interiéru.

Zariadenie bolo celé atypicky vybudované $\mathrm{z}$ kameňa, bez použitia tehál, vrátane roštu pece. Murivo bočných stien bolo kladené na hlinu, maltu použili len na korune múrov. Obvodové steny vykurovanej miestnosti spájali maltou. Ako tepelný akumulátor slúžili riečne okruhliaky, doložené priamo na rošte pece (obr. 1: 6), ako aj v deštrukcii zariadenia (sonda 4/06).

Na základe konštrukcie identifikujeme zariadenie ako IV. typ. V literatúre sa predpokladá, že priestor, kde sa nachádzalo, slúžil ako obydlie predstaveného (Gojdič/Paulusová 2010, 296; Hanuliak 1996, 308, obr. 2: 5), čo považujeme za nepodložené. Vzhladom na to, že ide o krídlo kláštora oproti kostolu, je vykurovaný priestor situovaný v typickej polohe pre refektár, resp. kalefaktorium.
Pre datovanie výstavby pece môžeme vychádzat’ z pozorovania, že hypokaustum je súčastou najstaršej stavebnej fázy kláštora. Stavebno-historický výskum sa $\mathrm{k}$ jej datovaniu vyslovene nevyjadruje. Z publikovaného textu vyplýva len rámcové vymedzenie po prvej písomnej zmienke z roku 1275 (Gojdič/Paulusová 2010, 298). Pôvodný archeologický výskum hl'adal počiatky kláštora v kontexte historických hypotéz V. Jankoviča (1965) už v druhej štvrtine 13. stor. (Hanuliak/Hoššo/Hunka 1996, 316 n.). Tie však boli postavené na nesprávnej interpretácii listiny z roku 1275 (Ragač 2006). Autori archeologického výskumu zdá sa nedocenili vlastné terénne zistenia, dokladajúce najstaršie aktivity na lokalite až v poslednej tretine 13. stor. Konkrétne ide o nálezy keramiky a štyri mince Ladislava IV. (1272-1290), získané z vrstvy ležiacej na podloží, ktorá bola narušená múrom severného krídla kláštora. Stratigraficky nasledujúce vrstvy datujú už autori výskumu na začiatok 14. stor. (Hanuliak/Hoššo/Hunka 1994, 315, obr. 5: 11: A, B). Vzhl'adom na uvedené fakty možno výstavbu hypokausta a zároveň najstaršiu fázu kláštora hl’adat' najskôr až na prelome 13. a 14. stor. V súlade s týmto pozorovaním sa existencia kláštora spomína $\mathrm{v}$ písomných prameňoch prvý raz v roku 1303 (Ragač 2006, 3).

Obdobie zániku hypokausta indikujú najmladšie nálezy z jeho zásypu, ktoré autor výskumu rámcovo datoval do 15. až 16. stor. (Hanuliak 1994, prír. č. 6). Artefakty získané počas revízneho výskumu a pochádzajúce z deštrukcie zariadenia (sonda 4/06) datujeme analogicky. Na prevádzku hypokausta však mala isto vplyv už prestavba kláštora, datovaná do druhej polovice 14., resp. prvej polovice 15. stor. Vtedy bola postavená krížová chodba (Gojdič/Paulusová 2010, 298) a istotne, ako jej pendant, predížené aj severné krídlo kláštora (obr. 1: 2, 3). V dôsledku toho sa obslužný priestor zariadenia ocitol v interiéri. $\mathrm{V}$ tomto kontexte upozorňujeme aj na odvodňovací kanál, zachytený v priestore pece, ktorý zretelne poukazuje na zmenu funkcie zariadenia ešte pred jeho zasypaním.

\subsection{Beckov, hrad - zariadenie č. 1}

Počas archeologického výskumu hradu Beckov v 70. rokoch bola čiastočne odkrytá a v roku 2020 znova začistená vel'ká pec, ktorú identifikujeme ako hypokaustum. ${ }^{11}$ Pec sa nachádza v hlavnom, dvojtraktovom, trojpodlažnom paláci na severnom konci horného hradu (obr. 2: 1, 3, 4, 6), ktorý zásadným spôsobom dostavali za Stiborovcov ( $\mathrm{k}$ dejinám rodu Dvořáková 2003). Starší, západný trakt paláca bol postavený už v polovici 13. stor. Na prvom poschodí mal priestor, ktorý zaberal celé podlažie a v ktorom sa predpokladá rytierska sála. Druhé nadzemné podlažie bolo postavené až za Stibora mladšieho (v rokoch 1414-1434). Mladší, východný trakt paláca pristavali ešte $\mathrm{v}$ rámci prestavieb Stibora staršieho (v rokoch 1388-1414). Pozostával z troch za sebou radených miestností, ktoré boli na poschodí spojené gotickými lomenými portálmi, a mal obytnú funkciu (Jančušková 1971, 70-90; Plaček/Bóna 2007, 58-62).

Pec sa nachádzala vo východnom trakte na prízemí, v juhozápadnom nároží severnej miestnosti (obr. 2: 4). Otvor do pece, široký 1,1 m, bol osadený v priečke a jeho

\footnotetext{
${ }^{10}$ Zahíbenie dna pod úroveň základovej škáry múrov komory môže byt๋ dôsledkom sekundárneho zásahu.

${ }^{11}$ Výskum uskutočnilo Trenčianske múzeum pod vedením J. Maleca, ktorému d’akujem za poskytnutie dokumentácie nálezu a možnost’ publikácie.
} 

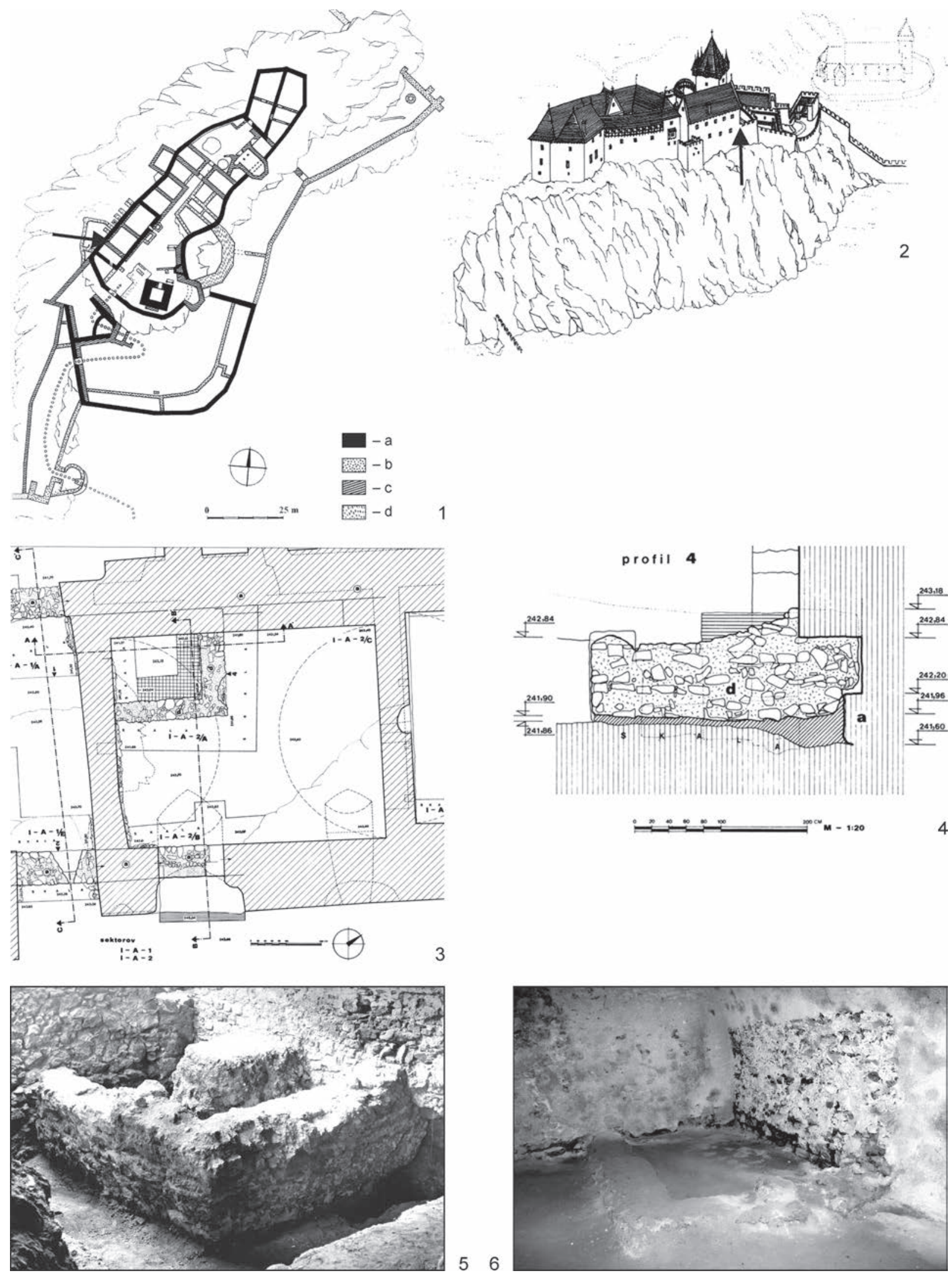

Obr. 3. Beckov, hrad, západný palác. 1 - pôdorys hradu s vyznačenou polohou pece; 2 - ideálna rekonštrukcia hradu s vyznačenou polohou pece (1, 2 podla Plaček/Bóna 2007); 3 - pôdorys pivnice západného paláca a pece; 4 - pohlad na severnú stenu pece; 5 - pohl'ad na pec počas výskumu (3-5 podla Tóthová 1978); 6 - pohl'ad na pec, aktuálny stav. Legenda: $\mathrm{a}-13$. stor.; $\mathrm{b}-14$. stor.; $\mathrm{c}$ - prvá tretina 15 . stor.; $\mathrm{d}-16$. stor. 
ostenie vyhotovili zo sekundárne použitých pieskovcových článkov, datovaných medzi roky 1240-1260 (obr. 2: 2). Pec mala rozmery $3,54 \times 2,74 \mathrm{~m}$ a miestami sa dochovala do výšky 1,8 m (obr. 2: 7). Vyhotovená bola z lomových kameňov. Severný a východný obvodový múr pece bol široký $0,8 \mathrm{~m}$. Vonkajší plášt bol spájaný maltou a ako ukázal výskum z roku 2020 pec mala aj vnútornú konštrukciu spájanú hlinou minimálne na západnej strane (šírka 0,45 m), ktorá vykurovaciu komoru oddelovala od obvodového múru paláca (obr. 2: 5). Objekt bol v 70. rokoch preskúmaný a zdokumentovaný len čiastočne, a to z vonkajšej strany, jeho vnútro nebolo odkryté kvôli statike paláca. Výskum z roku 2020 ho taktiež len očistil (obr. 2: 5, 7). Na vrchu sutiny v interiéri pece sa nachádzali väčšie aj menšie prepálené riečne okruhliaky, prepálená červenkastá hlina, ako aj fragmenty tehál. Pri vstupe do pece sa zachovala podlaha vykurovacej komory tvorená prepálenou hlinou, zadná čast’ komory bola deštruovaná pod úroveň podlahy. Dymovod bol umiestnený v priečke miestnosti nad vstupom do pece (obr. 2: 6). Zariadenie bolo obsluhované zo strednej miestnosti východného traktu a podlahu tu, ako aj na celom v prízemí, tvorila zrejme len udupaná hlina (úroveň 248,1 m n. m.). ${ }^{12}$ Možnoste použitia tehlovej dlažby, dochovanej vo vedlajšom západnom trakte paláca, tu len hypoteticky naznačovali úlomky tehál. Vykurovaná miestnost' mala polygonálny pôdorys s maximálnymi rozmermi $11,5 \times 7,3 \mathrm{~m}$ a plochou cca $81,41 \mathrm{~m}^{2}$ (obr. 2: 6). Všetky podlažia obidvoch traktov paláca mali rovné trámové stropy. Len prízemie západného traktu bolo počas stiborovských prestavieb zaklenuté valenou klenbou (obr. 2: 4; Jančušková 1971, 75, 87; Tóthová 1978, 91, 124).

Autori výskumu interpretovali zariadenie ako pec na chlieb (Kodoňová/Tóthová 1995, 52). Tento názor považujeme za nepravdepodobný vzhl'adom na vel'ké rozmery zariadenia a jeho situovanie pod hlavnými obytnými priestormi luxusnej šlachtickej rezidencie. Okrem toho, prítomnost' prepálených riečnych okruhliakov v konštrukcii pece, ako aj fragmenty tehál umožňuje identifikovat’ objekt ako hypokaustum IV. typu. Podla autorov výskumu bola pec sekundárne pristavaná niekedy v priebehu 15. stor., najneskôr začiatkom 16. stor. (Tóthová 1978, 91). Toto tvrdenie však spochybňuje skutočnost', že dymovod pece bol vstavaný v priečke miestnosti, čo dokladá grafická dokumentácia prvého nadzemného podlažia (obr. 2: 6). Priečku, ako aj východný trakt paláca postavili počas prestavby Stibora staršieho, takže konštrukciu pece môžeme zaradit medzi roky 1388-1414. Uvedené datovanie sa javí pravdepodobnejšie aj s ohl'adom na to, že v 15. stor. už vykurovanie početných obytných priestorov beckovského hradu doplńali okrem krbov skôr kachlové pece, doložené nálezmi reliéfne zdobených komorových kachlíc (Kodoňová/Tóthová 1995).

\subsection{Beckov, hrad - zariadenie č. 2}

Ďalší podobný objekt bol počas výskumu odkrytý aj v západnom paláci hradu Beckov (obr. 3). Ten tvorí trojpodlažný, v južnej časti podpivničený objekt (36-41 x 8 m), ktorý ma dosial tri identifikované stavebné etapy. Prvá sa datuje k polovici 13. stor. Druhá etapa, ktorá čiastočne využila obvodové múry prvého paláca, pochádza z prvej tretiny 15. stor. Tretia a posledná prestavba sa uskutočnila okolo polovice 16. stor. Jej súčastou bolo aj zvýšenie paláca o tretie nadzemné podlažie (Jančušková 1972, 48-73; Kodoňová/Tóthová 1995, 68-74; Plaček/Bóna 2007, 58-62). Vybudovanie zariadenia bolo súčastou druhej stavebnej etapy, resp. na ňu nadväzovalo.

Zariadenie sa nachádzalo v úrovni suterénu v juhozápadnom nároží južnej miestnosti paláca (obr. 3: 1, 3). Suterénna miestnost mala pôvodne drevený trámový strop, pričom obytný priestor nad ňou mal rovnakú dispozíciu a rozmery $7,5 \times 6,1 \mathrm{~m}\left(45,75 \mathrm{~m}^{2}\right)$. Podlahu v suteréne tvorila v 15. stor. len udupaná hlina (úroveň $242,94 \mathrm{~m} \mathrm{n}$. m.). Zariadenie bolo pristavané k obvodovým múrom paláca a zapustené do híbky cca $1 \mathrm{~m}$. Objekt mal vnútorné rozmery 2,5 $33 \mathrm{~m}$ (obr. 3: 3). Jeho múry, široké $0,7 \mathrm{~m}$, boli vybudované $\mathrm{z}$ lomového kameňa spájaného maltou a zachovali sa do výšky 0,9 cm (úroveň koruny 242,8 m n. m.; obr. 3: 4, 5). Dno objektu tvorila udupaná hlina. Zariadenie bolo prístupné z exteriéru 1,3 m širokým otvorom, situovaným excentricky v juhozápadnom nároží paláca (obr. 3: 4, 5). Prah vstupu ležal o 0,46 m vyššie (úroveň $242,50 \mathrm{~m} \mathrm{n}$. m.) ako identifikovaná podlaha objektu. V exteriéri, kde možno predpokladał́ jeho obslužný priestor, priliehala k nemu v rovnakej úrovni tehlová dlážka, osadená v maltovom lôžku (Tóthová 1978, 434-440).

Zariadenie zaniklo počas renesančnej prestavby paláca v polovici 16. stor. (tretia etapa). Vtedy bola do miestnosti vložená valená klenba, ktorá nahradila pôvodný trámový strop. Klenba sčasti zakryla aj vstup do zariadenia, pričom na zvyšnom úseku bol zamurovaný (obr. 3: 5). Objekt rozobrali po vtedajšiu pochôdznu úroveň. Deštrukciou z prestavby bol vyplnený priestor zariadenia a jeho dochovanú korunu prekryla stavebná sutina, obsahujúca keramiku z 16. a 17. stor.

Vzhladom na situovanie objektu v suteréne, resp. na prízemí, pod gotickými obytnými priestormi, ako aj na jeho datovanie $v$ rámci honosnej stiborovskej prestavby možno uvažovat', že ide o torzo teplovzdušného zariadenia. Aj stavebno-historický výskum identifikoval objekt ako pec bez bližšej špecifikácie (Jančušková 1972, 54; Kodoňovál Tóthová 1995, 72). Situáciu však zneistuje len čiastočný plášt pece, pristavaný k obvodovým múrom paláca, spájaný maltou, čo je technicky nevhodné riešenie. Mohlo by však íst’ o vonkajší plášt’ ako pri prvej peci. Atypický je aj vyššie situovaný vstup do zariadenia než jeho podlaha, i ked' $\mathrm{k}$ tomu poznáme analógiu v prípade hypokausta $\mathrm{z}$ hradu Vranov nad Dyjí (Konečný 1983, 450, obr. 2; 3). Interpretáciu objektu ako teplovzdušnej pece nemožno s istotou potvrdit, avšak ani vylúčit. V tejto súvislosti ešte spomeňme, že dve severne situované, susedné miestnosti na prvom poschodí západného paláca boli vykurované krbom, vstavaným v spoločnej priečke (Jančušková 1972, 54).

\subsection{Hronský Beňadik, kláštor benediktínov}

Kláštor založil knieža Gejza v roku 1075, resp. krátko predtým. Od polovice 14. stor. sa začal pôvodný románsky kostol prestavovat' v gotickom slohu. Z roku 1405 pochádza listina pápeža Inocenta VII., ktorá podporuje znovu postavenie poškodeného kláštora. Práce na prestavbách

\footnotetext{
12 Tá však bola viac-menej prepojená s prvou južnou miestnostou, nakol'ko priečku na úrovni prízemia tvoril velký, otvorený, klenutý oblúk.
} 

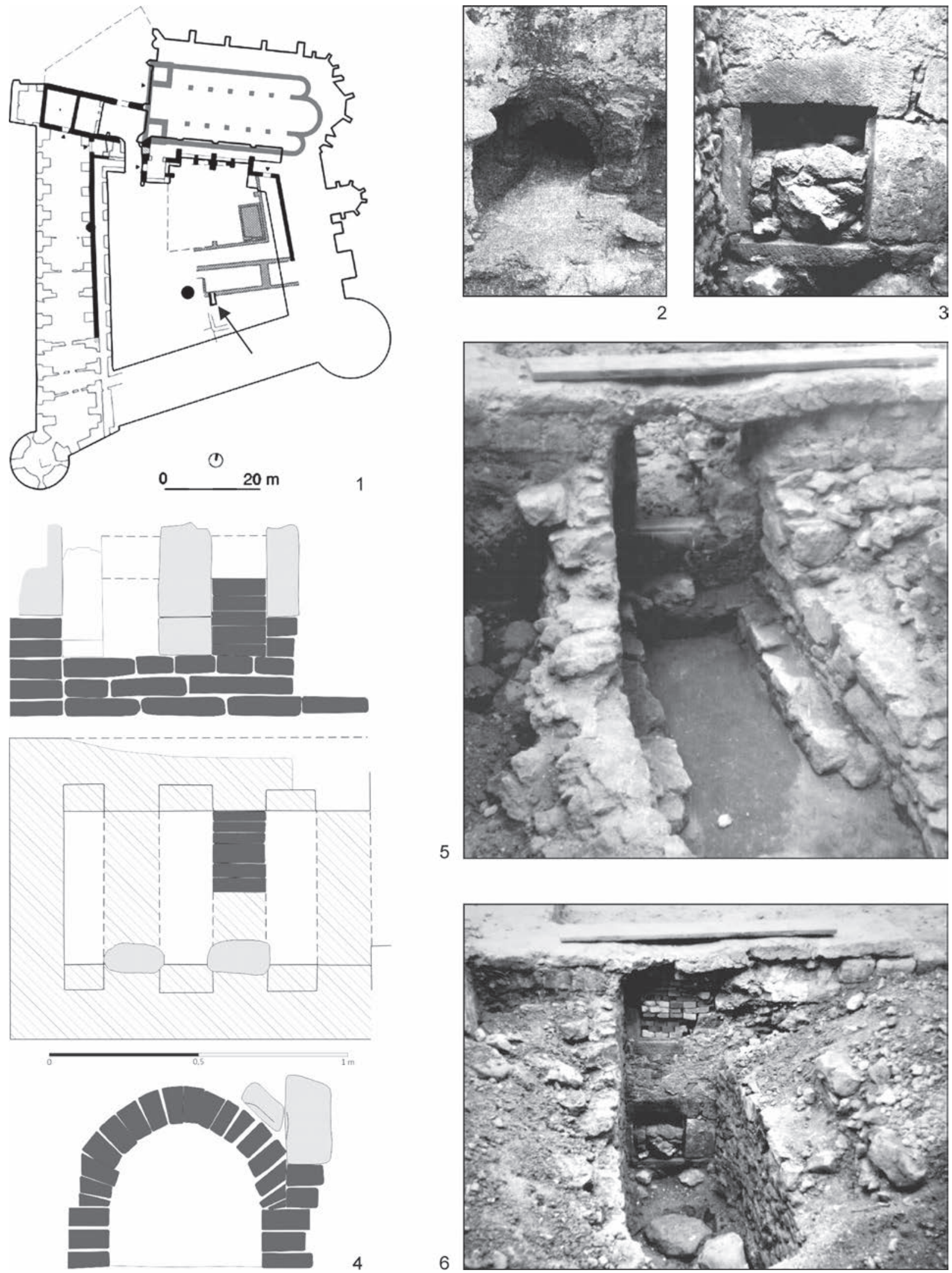

Obr. 4. Hronský Beňadik, kláštor benediktínov. 1 - plán kláštora a protitureckej pevnosti s vyznačenou polohou pece (podla Haviar 2013); 2 - pohlad do vnútra pece (podla Habovštiak/Holč́́k 1975b); 3 - detail spodného prikladacieho otvoru pece; 4 - pôdorys, priečny a pozdlžny rez pecou; 5 - pohl'ad na hornú čast’ obslužného priestoru pece počas odkrývania; 6 - obslužný priestor pece (3-6 autor Š. Holčík). 
komplexu pokračovali vo viacerých etapách až do začiatku 16. stor. (Haviar 2013; Mencl 1966; Oriško 2003; Pomfyová 2015, 736-739; Puškárová 1975; k dejinám Keglevich 2012). Mnísi opustili opátstvo po roku 1528 (Jankovič 1975, 7). V priebehu 16. stor. došlo k jeho prestavbe na protitureckú pevnost', pričom niektoré časti, najmä južný trakt, boli pri prestavbe zbúrané (Puškárová 1975, 11).

Počas systematického výskumu v rokoch 1972-1976 bol odkrytý takmer celý kláštor (Habovštiak/Holčík 1994) a v jeho južnom krídle bola lokalizovaná vykurovacia pec (obr. 4: 1). ${ }^{13}$ Nachádzala sa v juhozápadnom nároží pivnice pod refektárom $(4,1$ x 12,3 m; 56,58 m²). Pec bola osadená v pivnici a obslužný priestor vybiehal smerom na juh do exteriéru, odkial' bol zariadenie prístupné (Habovštiak/ Holčík 1994, 143 n.).

Architektúru pece tvorila malá obdĺžniková stavba $\mathrm{s}$ vonkajšími rozmermi 1,01 x 1,2 m (obr. 4: 2, 4). Vnútorná komora mala svetlost $1,03 \times 0,51 \mathrm{~m}$. Jej podlaha bola vyložená plochými kameňmi a vo výške $19 \mathrm{~cm}$ od dna vytvárali bočné steny sokel široký $8-9 \mathrm{~cm}$, na ktorý dosadal rošt pece. Pozostával z troch klenbových pásov, vyhotovených $\mathrm{z}$ jedného radu tehál (výška 0,65 m, rozpon 0,69 m). Volný priestor medzi nimi mal približne šírku jednej tehly. Severná čast’ zariadenia bola poškodená a západná stena bola silne očadená od sadzí. Zariadenie vyhotovili z tehál (24-25 x 12-13 x 5-6 cm) v kombinácii s opracovanými kameňmi, konkrétne z tufu, čadiču a vápenca. Ako spojivo bola použitá hlina prepálená do červena. V hornej časti pece sa nachádzala silno zadymená kamenná doska s rozmermi $34 \times 100 \mathrm{~cm}$. Z dostupnej dokumentácie nepoznáme jej presnú polohu, avšak pravdepodobne išlo o podlahovú platňu.

Obslužný priestor zariadenia sa nachádzal v exteriéri (obr. 4: 1, 5, 6). Tvorila ho zahíbená obdĺžniková jama $(2,3 \times 1,2 \mathrm{~m})$ so stenami z lomového kameňa, pristavanými k južnej obvodovej stene kláštora. Pec bola prístupná z obslužného priestoru. Nakol'ko to možno posúdit’ z dostupnej fotodokumentácie, jej vstup bol vstavaný priamo do steny kláštora, z čoho vyplýva, že sú súčasné. Vstup pece tvoril pravouhlý otvor s rozmermi $61 \times 55 \mathrm{~cm}$, vyhotovený zo štyroch vel'kých, opracovaných kvádrov nesúcich stopy od ohňa, ktoré mali na okraji vyformovaný ústupok pre dvierka (obr. 4: 3, 6). Za vstupom sa v hrúbke muriva kláštora lievikovite rozširoval priestor pece. Nad spodným otvorom sa o $74 \mathrm{~cm}$ vyššie v osi nachádzal druhý, analogický otvor. Takisto bol vstavaný do obvodovej steny kláštora a taktiež ho vyhotovili z opracovaných kvádrov s drážkou pre dvierka, široké $37 \mathrm{~cm}$. Horný otvor pravdepodobne slúžil na odvod dymu v prípade, že pec nemala komín, resp. na prívod čerstvého vzduchu k rozpálenému roštu vo vykurovacej fáze. Obidva otvory boli pri prestavbách suterénu zamurované (Habovštiak/Holčík 1972, 14 n.; 1974, 5-9, 20, 21; 1975c, 22, 23, 29, 30, 48, 49; 1976, 3).

Z archeologického výskumu vyplýva, že pivnica, $\mathrm{v}$ ktorej bola pec osadená, vznikla minimálne v dvoch stavebných fázach, pričom jej juhozápadná čast̉ s vyku- rovacím zariadením bola identifikovaná ako najstaršia. Suterén bol pôvodne prekrytý plochým, dreveným stropom a jeho podlahu tvorila len udupaná hlina. Neskôr ju zaklenuli valenou klenbou, ktorá prekryla viacero starších otvorov, ako aj samotnú pec (Habovštiak/Holčík 1975a, 73; 1994, 144). Táto prestavba nám definuje najneskorší termín vyradenia hypokausta. Na dobu jeho zániku by mohol poukazovat nález kachlovej pece v zásype pivnice, ktorá je na základe ikonografie datovaná vel'mi presne do polovice 15. stor., k roku 1457 (Holčík 1978, 21-24, obr. 14). Kachle tu zrejme nahradili staršie zariadenie, ktoré vykurovalo refektár.

Vzhl'adom na konštrukciu roštu identifikujeme skúmaný objekt ako hypokaustum IV. typu, ktoré sa podla chronológie K. Bingenheimera $(1998,196)$ objavuje od 14. stor. Autori výskumu však pec z Beňadiku, ako aj najstaršiu čast’ suterénu datujú do románskeho obdobia (Habovštiak/ Holčík 1975a, 72). Bližšie argumenty pre toto zaradenie ale neuvádzajú. ${ }^{14}$ Domnievame sa, že ich výstavbu bude treba posunút až do gotickej prestavby kláštora. Predpokladá sa, že ju začal opát Siegfried (1330-1355) a pokračovali v nej aj nasledujúci opáti (Haviar 2013, 116). Obdobie okolo polovice 14. stor. bolo zároveň dobou, kedy technológia, konkrétne IV. typ pecí, zažívala svoj zenit (Hanuš 2016, 42).

\subsection{Košice, kláštor dominikánov}

Založenie dominikánskeho kláštora v Košiciach sa podla novších názorov kladie do obdobia vlády Bela IV. (Nádaská 2011, 124, 125). Prvá písomná zmienka o kláštore pochádza z roku 1303 (Hunčaga 2008, 41) a výstavba kostola sa datuje od konca 13. stor. do prvej polovice 14. stor. (Gojdičl Paulusová 2010,301), resp. na prelom 13. a 14. stor. (Pomfyová 2018, 94-97), alebo až do poslednej tretiny 14. stor. (Volovár 2017, 218). Dominikáni opustili Košice po náboženských nepokojoch a po požiari mesta v roku 1556. V roku 1699 sa dominikáni vrátili a v priebehu 18. stor. obnovili kostol, pričom pôvodný kláštor nahradili novým barokovým objektom (Wick 1932, 11-29).

Na lokalite sa uskutočnilo viacero archeologických výskumov (P. Mačala 1984-1990, J. Béreš 1997, M. Ďurišová 2000, R. Rusnák 2006-2010), ako aj stavebno-historický výskum a objekt bol predmetom niekol'kých štúdií (dejiny bádania naposledy podrobne zhrnul Rusnák/Volovár 2013). Z pôdorysu dominikánskeho kláštora sú identifikované čiastočné úseky zo všetkých troch krídel kvadratúry (Rusnák/Volovár 2013). ${ }^{15}$

Počas poslednej série archeologických výskumov bola v severom krídle kláštora odkrytá teplovzdušná pec (obr. 5: 1; Rusnák 2009, 36, 37, 68-71, 102; 2018, 188-191; Rusnák/ Volovár 2013, 177, 183, obr. 13). ${ }^{16}$ Vykurovaný tu bol menší priestor (cca $25 \mathrm{~m}^{2}$ ), k múrom ktorého bolo hypokaustum sekundárne pristavané (obr. 5: 2, 6), pričom pec sa nachádzala pod podlahou miestnosti a obslužný priestor bol prístupný z inej miestnosti (cca $\left.9 \mathrm{~m}^{2}\right)$, takisto $\mathrm{v}$ interiéri.

\footnotetext{
${ }^{13}$ Ďakujem Štefanovi Holčíkovi za poskytnutie dokumentácie nálezu.

${ }^{14}$ Predpokladáme, že by mohlo súvisiet s použitým kvádrikovým murivom, čiastočne viditelným na nepublikovanej fotodokumentácii (obr. 4: 5, 6). Môže však íst’ o sekundárne použitý stavebný materiál, čo sa ukázalo aj v iných častiach gotického kláštora (Haviar 2013, 115 n.).

${ }^{15}$ Uvažuje sa, že pôdorys kláštora je zachytený na pláne talianskeho stavitela Alexandra Canovala zo 17. stor. Plán však vykazuje viaceré metrické, ale aj zásadné dispozičné nezhody s dosial' identifikovaným pôdorysom.

${ }^{16}$ Ďakujem R. Rusnákovi za sprístupnenie dokumentácie nálezu.
} 

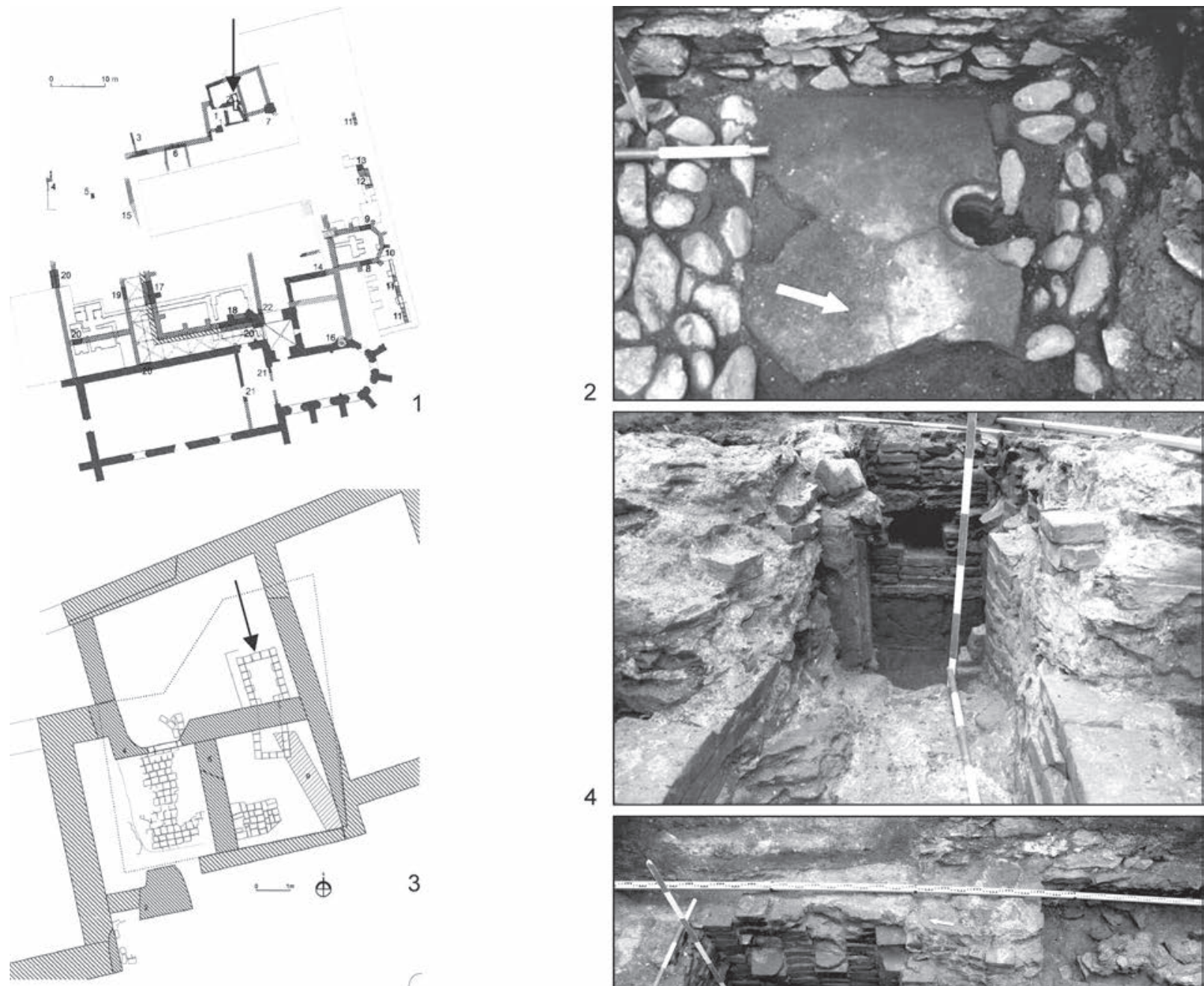

3
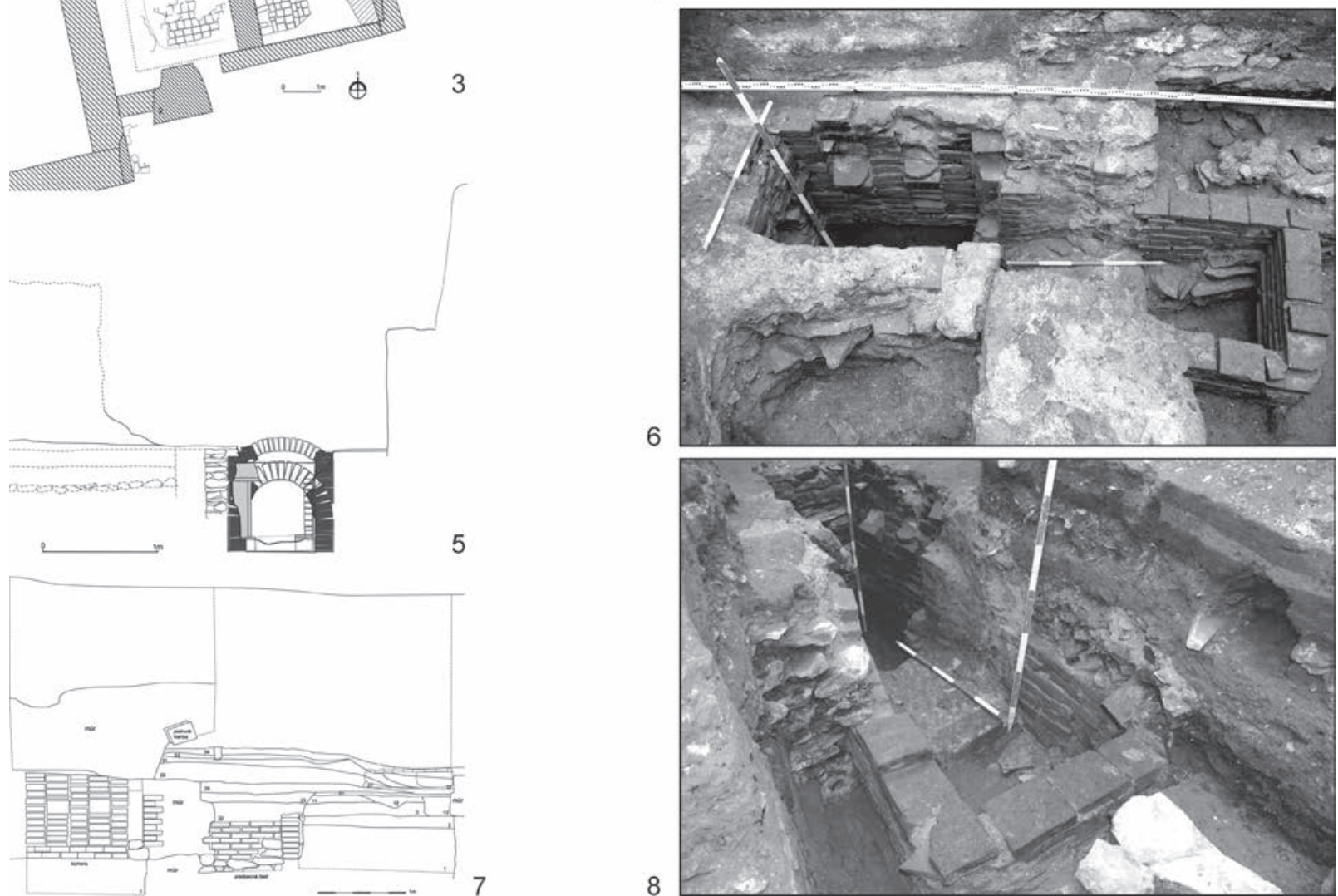

Obr. 5. Košice, kláštor dominikánov. 1 - plán kláštora s vyznačenou polohou pece (podla Rusnák/Volovár 2013); 2 - nález podlahovej platne (podla Rusnák 2009); 3 - širšia situácia a pôdorys pece; 4, 5 - pohlad na vstup do pece; 6 - celkový pohl’ad na zariadenie; 7 - bočný pohlad na pec a obslužný priestor (3-5, 7 podl’a Rusnák 2018); 8 - obslužný priestor pece (6, 8 autor R. Rusnák). 
Vykurovacia komora mala obdížnikový tvar s vnútornými rozmermi $1,2 \times 0,8 \mathrm{~m}$ a zachovala sa do výšky $1 \mathrm{~m}$ (obr. 5: 6, 7). Vnútro mala vymurované z tehál štvorcového, dlaždicového formátu s priemernými rozmermi 22,2 x 18,6 x 5,2 cm. ${ }^{17}$ Pec mala vyhotovený aj vonkajší plášt z kameňa spájaného maltou (obr. 5: 6). Z bočných stien vnútri pece vybiehali po dva rady tehál a vytvárali nábeh na dva klenbové oblúky roštu pece, ktorý sa nedochoval (obr. 5: 5, 6). Rošt pravdepodobne nepresahoval zachovanú výšku vykurovacej komory (obr. 5: 5). Nad ním sa zrejme nachádzala ešte jedna klenba tvoriaca strop pece, ktorá výškou už presahovala dochované murivo. Ako sme spomenuli, pec bola pristavaná k staršiemu múru, ktorý v mieste vstupu do pece rozobrali (obr. 5: 6). Vstup do komory lemovalo čiastočne zachované kamenné ostenie vo forme kvádra s drážkou pre obdížnikovité, zrejme kovové dvere (obr. 5: 4,5). Dno pece tvorila tenká maltová vrstva na podloží. Stopy po ohni sa črtali na bočných stenách od úrovne roštu pece, najmä však na západnej stene. Odvod dymu z pece sa nepodarilo identifikovat.

Počas výskumu sa našla jedna kamenná platňa so vzduchovodom, ktorá mohla prekrývat’ pec. Situovaná bola, ned’aleko hypokausta v sekundárnej polohe, použitá ako súčast' okruhliakovej dlažby, datovanej do 15. stor. (obr. 5: 2). Platňa bola hrubá $10,6 \mathrm{~cm}$, široká viac ako $68 \mathrm{~cm}$, pričom priemer jej otvoru bol 9,6 cm a obežného žliabku cca $17 \mathrm{~cm}$. Platňa by mohla poukazovat na skorý zánik hypokausta, resp. predstavuje sekundárne použitý nepodarok z jeho výstavby. Inou alternatívou je, že by mohla naznačovat' existenciu d’alšieho, zatial' nelokalizovaného hypokausta v kláštore.

Obslužný priestor pece bol vybudovaný z rovnakých štvorcových tehál a mal rozmery 0,95 x 1,05 m (obr. 5: 4, $6,7,8)$. Zachoval sa do výšky siedmych radov tehál. Predpecný priestor bol voči osi vykurovacej komory pristavaný s $9^{\circ}$ vychýlením na západ a pôvodne bol zaklenutý ako naznačili zvyšky klenby nájdené v deštrukčných vrstvách datovaných do 17. stor.

Na základe konštrukcie prirad’ujeme pec k IV. typu teplovzdušných zariadení. Tehly dlaždicovitého formátu, z ktorých bola postavená, datuje autor výskum do 15. stor. (Rusnák 2009, 102; 2018, 191). Hypokaustum bolo zahĺbené do vrstiev, ktoré obsahovali keramický materiál, ako aj viacero mincí z 30 . až 60. rokov 15 . stor., na základe čoho autor výskumu datuje jeho výstavbu do záveru tretej štvrtiny 15. stor. (obr. 5: 5, 7; vrstvy 3 a 15; Rusnák 2018, 189, 190). Na skorý zánik pece môže poukazovat nález kamennej platne, sekundárne použitej v dlažbe rámcovo datovanej do 15. stor., ako aj málo početné neskorogotické nálezy zo zásypu zariadenia, medzi nimi aj fragmenty komorových glazovaných kachlíc $\mathrm{s}$ neskorogotickou ornamentikou, rámcovo z druhej polovice 15. stor. (Rusnák 2009, 71 n., 107 n.). Svoju funkciu stratila pec najneskôr po odchode dominikánov z Košíc v roku 1556 a zasypaná bola v druhej polovici 16. stor. Nálezy kachlíc z rovnakého obdobia ako hypokaustum naznačujú, že vykurovanie v kláštore zabezpečovali paralelne staršou teplovzdušnou technológiou aj modernejšími kachlovými pecami.

\subsection{Košice-Krásna, kláštor benediktínov}

Benediktínsky kláštor v Košiciach-Krásnej bol založený v roku 1143 a zanikol v priebehu prvej polovice 16. stor. Počas systematického výskumu v rokoch 1971-1981 bol preskúmaný v celom rozsahu (Polla 1986; Pomfyová 2015, 748-752).

V severnom krídle kláštora bolo odkryté teplovzdušné zariadenie (Polla 1977, 12 n., 20-24, 35 n.; 1978, 11-24, 40-42; $1986,143-152) .^{18}$ Nachádzalo sa v západnej miestnosti s rozmermi 5,5 x 9,5 m (52,25 m²), predstavujúcej najväčší priestor v kláštore, ktorý možno pravdepodobne identifikovat' ako refektár (obr. 6: 1). Hypokaustum bolo situované v severovýchodnom nároží miestnosti pri obvodovom múre a vnútornej priečke. Vykurovacia čast’ pece bola pod podlahou interiéru a prístupová šachta v exteriéri, za obvodovým múrom.

Pec tvorila pravidelná obdĺžniková komora s vnútornými rozmermi 2,11 x 0,81 cm a s tehlovými múrmi hrubými 0,51-0,57 m (obr. 6: 3)..$^{19}$ Odlišná bola južná stena komory, vymurovaná z kameňov (obr. 6: 6). Po stranách komory sa dochovalo torzo ríms, o ktoré sa opieral dnes už nedochovaný rošt pece (obr. 6: 2, 6). Vykurovacia komora bola prístupná cez malý zaklenutý portál na severnej strane dlhý 0,4 m, široký 0,46 m a vysoký 0,71 m (obr. 6: 2, 3).

V exteriérovej časti sa nachádzal obslužný priestor, resp. vstupná šachta takmer štvorcového tvaru s vnútornými rozmermi 1,52 x 1,72 m (obr. 6: 2, 3). ${ }^{20}$ Excentricky pri východnej stene sa otvárala smerom na juh do užšieho koridoru, širokého 1,09 m a dlhého 0,79 m, ktorý sa pripájal k vstupnému otvoru do vykurovacej komory. Steny prístupovej šachty boli vymurované $\mathrm{z}$ tehál a zachovali sa do výšky $0,81 \mathrm{~m}$. Ich hrúbka sa pohybovala v rozsahu 0,3 až $0,44 \mathrm{~m}$.

Celkovo bolo hypokaustum dlhé 5,66 m, pričom vykurovacia čast' mala 2,97 $\mathrm{m}$ a obslužný priestor 2,66 m. Dno pece sa nachádzalo $\mathrm{v}$ hĺbke približne $1,1 \mathrm{~m}$ pod interiérovou podlahou a vo vykurovacej aj obslužnej časti bolo pokryté opotrebovanými tehlovými dlaždicami s rozmermi 19-20,5 x 19-20,5 x 2,5-3,5 cm. Rovnaká dlažba bola použitá aj v interiéri refektára.

Severný obvodový múr kláštora, široký 1,34 m, prebiehal v časti nad vstupným portálom a vykurovacou komorou. $\mathrm{V}$ jeho hrúbke, približne na úrovni podlahy, sa západne v dotyku s vykurovacou častou hypokausta nachádzala komora s vnútorným rozmerom $0,83 \mathrm{x}$ $1,25 \mathrm{~cm}$ (obr. 6: 2-4). Na východnej strane smerom k peci hypokausta mala komora otvor široký $35 \mathrm{~cm}$ a vysoký minimálne $45 \mathrm{~cm}$. Otvor mal ostenie vytvorené z malých kamenných stĺpikov, údajne profilovaných pre dvierka, a zhora ho prekrýval železný pás $(5 \times 1 \times 67 \mathrm{~cm})$. Dno komory bolo vyložené okruhliakmi a za ostením, pri stene hypokausta, škridlami $(21-24 \times 40 \times 2-2,5 \mathrm{~cm})$.

\footnotetext{
${ }^{17}$ Využívali sa aj ako interiérová dlažba.

18 Ďakujem K. Füryovej a R. Čambalovi za sprístupnenie dokumentácie nálezu.

${ }^{19}$ Metrické údaje zariadenia uvádzame podla výkresov výskumnej dokumentácie a trochu sa odlišujú od údajov publikovaných autorom výskumu.

${ }^{20}$ B. Polla $(1986,146)$ ju mylne interpretuje ako saunu.
} 

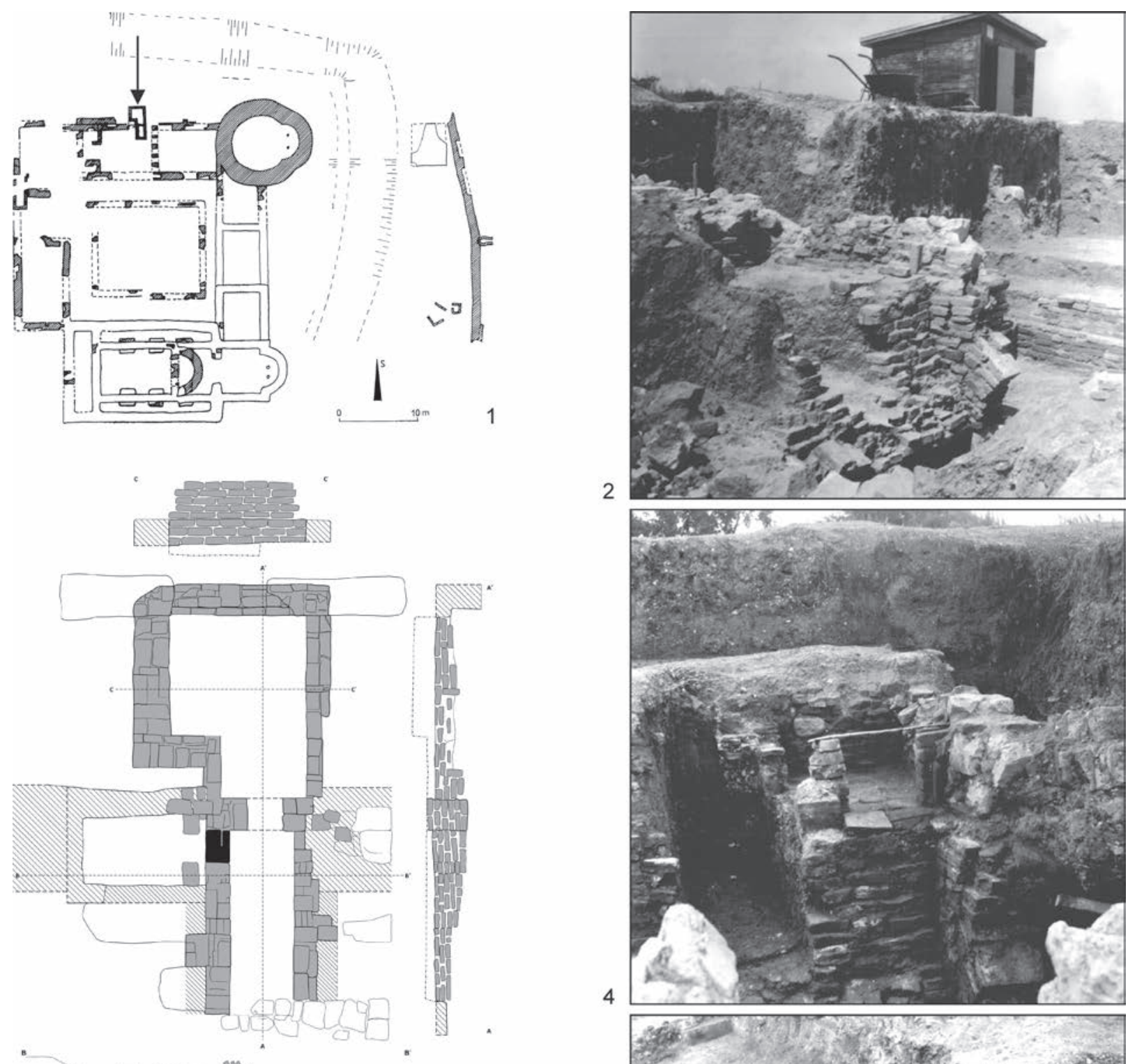

2
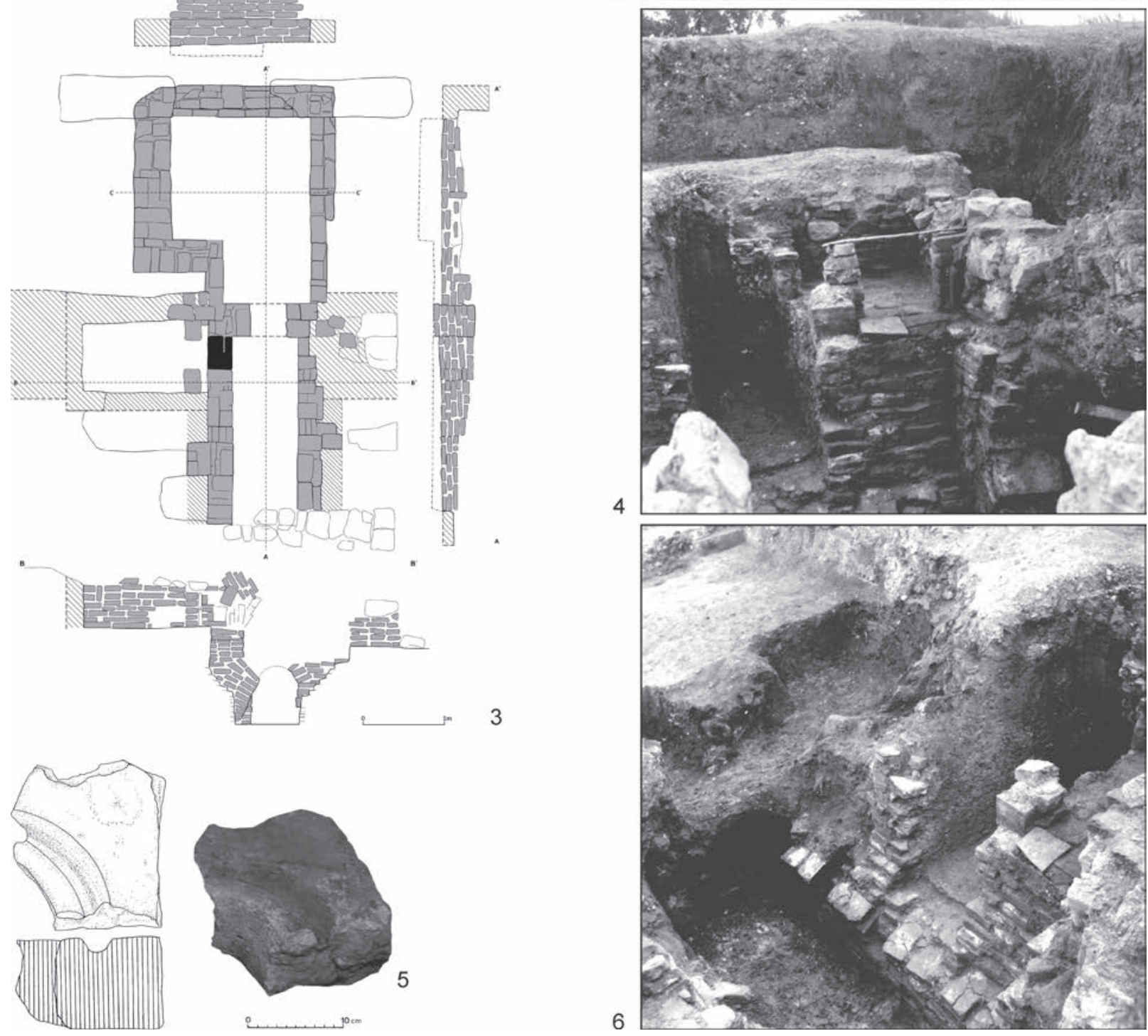

Obr. 6. Košice-Krásna, kláštor benediktínov. 1 - plán kláštora s vyznačenou polohou pece; 2 - celkový pohlad na zariadenie; 3 - pôdorys zariadenia, bočný pohlad, čelný pohlad zvnútra pece a pohl'ad na zadnú stenu obslužného priestoru; 4 - detail na pravdepodobné torzo dymovodu; 5 - keramický fragment podlahovej platne so vzduchovodom (1, 3, 5 podla Polla 1986); 6 - pohl'ad do vnútra pece (2, 4, 6 autor B. Polla). 
Fragmenty škridiel sa našli aj v zásype komory. Severná stena komory bola hrubá max 0,38 m, južnú narušil novoveký hrob. Komoru identifikujeme ako torzo dymovodu, situovaného v hrúbke novovybudovanej obvodovej steny kláštora. ${ }^{21}$

Okrem južnej steny bolo hypokaustum vyhotovené z plevových tehál s rozmermi 32,5 x 17,5 x 4,5 cm, kladených na hlinu. $V$ zásype zariadenia sa nachádzali riečne okruhliaky, pochádzajúce $z$ roštu zariadenia. Medzi publikovanými nálezmi z výskumu sa nám podarilo identifikovat aj tehlový fragment podlahovej platne so vzduchovodom lemovaným žliabkom (hrúbka $11 \mathrm{~cm}$; obr. 6: 5; Polla 1986, 250, obr. 16: 2; 123: 1). Zmiešané kamenno-tehlové murivo bolo použité v severnom obvodovom múre kláštora, zrejme ako dôsledok prestavby pri konštrukcii hypokausta.

Podla autora výskumu predstavuje zariadenie jednu z posledných stavebných úprav architektúry kláštora a opatrne ho interpretuje ako vykurovacie zariadenie so saunou a s pecou na prípravu jedál (Polla 1986, 150 n.). Podla nás možno údajnú saunovaciu komoru identifikovał ako vstupnú šachtu a obslužný priestor hypokausta a pec, situovanú v obvodovej stene kláštora ako dymovod.

B. Polla $(1986,151$ n.) vzhladom na nález množstva hrubostenných pohárovitých kachlíc $\mathrm{v}$ tomto priestore d’alej predpokladá, že vykurovacie zariadenie bolo nadstavané kachl'ovou pecou. K. Bingenheimer (1998, 189-194) sa zaoberal možnostou existencie takýchto hybridných vykurovacích telies. Po podrobnej analýze dvoch potenciálnych prípadov však ich existenciu vylučuje s poukázaním na úplne odlišný vykurovací princíp. Kachlová pec v Krásnej pravdepodobne predstavuje samostatný mladší objekt, ktorý nahradil vykurovaciu funkciu hypokausta, čo je charakteristický jav aj na d'alších lokalitách. Pohárovité kachlice teda datujú skôr ukončenie používania hypokausta, a nie jeho vznik, ako usudzuje autor výskumu. ${ }^{22}$ Objekt identifikujeme ako hypokaustum IV. typu a jeho výstavbu a používanie rámcovo datujeme do 14. až 15. stor.

V kláštore bol odkrytý aj d’alší analogický objekt, pri ktorom autor výskumu zvažuje vykurovaciu funkciu. Nachádzal sa v západnom krídle kláštora (obr. 6: 1; Polla 1975, 27, výkres 11; 1978, 44 n.; 1986, 98, obr. 42). Objekt sa nachádzal severne aj južne od priečky vymedzujúcej strednú a severnú miestnosṫ západného krídla. Autor výskumu uvažuje o jeho vykurovacej funkcii, resp. o použití v kuchyni, ktorú predpokladá v tomto priestore (Polla 1986, 98). Situovanie kanála v západnom krídle kláštora skôr naznačuje výrobný charakter, nakol'ko tu bývali tradične umiestnené skladové a hospodárske priestory. V prípade Krásnej to dokladá pivnica situovaná v susednej južnej miestnosti. V tomto kontexte možno spomenút, že z exteriéru v zázemí kláštora poznáme d’alší murovaný zahíbený kanál, dlhý $5 \mathrm{~m}$, ktorý má však tvar písmena T (Luštíková 2008, 334, obr. 3: 4; 5). V prípade pecí takejto formy sa často uvažuje o ich funkcii sušiarne obilia, sladu, alebo udiarne. Pre interpretovanie zariadenia v západnom krídle kláštora ako teplovzdušnej pece nenachádzame dostatok indícií. Vzhl'adom na uvedené usudzujeme, že objekt mal skôr výrobnú funkciu.

\subsection{Leles, kláštor premonštrátov}

Konvent sv. Kríža v Lelesi bol založený medzi rokmi 1188-1196. Krátko nato, na konci 12. stor., došlo pri spore medzi králom Imrichom a jeho bratom Ondrejom $\mathrm{k}$ jeho zničeniu. Po urovnaní sporu na začiatku 13. stor. kláštorný kostol obnovili. Osud stavby následne nepriaznivo zasiahol tatársky vpád, po ktorom sa predpokladá jeho d’alšia obnova (Pomfyová 2015, 765, 766; Žažová 2018). Stavebný vývoj objektu sa podla najnovších výskumov kreoval vo viacerých stredovekých a novovekých etapách od polovice 13. stor. (Kürthy/Glocková 2012). ${ }^{23}$

V rokoch 2013 a 2014 sa na lokalite realizoval archeologický výskum, ktorý pri plošnom odkryve rajského dvora, približne v jeho strede, odkryl základy pôvodného severného krídla kláštora (obr. 7: 5). ${ }^{24}$ Tie sa pravdepodobne napájali na najstaršiu identifikovanú čast̉ stojaceho konventu, datovanú do konca 13. až začiatku 14. stor. (obr. 7: 1 - zhruba južná polovica západného a východného krídla kláštora; Kürthy/Glocková 2012). V západnej časti odkrytého traktu, v rohu miestnosti vymedzenej priečkou, bola odkrytá teplovzdušná pec.

Pec bola vybudovaná pravdepodobne zo sekundárne použitých tehál spájaných hlinou. Naznačujú to ich fragmenty, niekedy aj so stopami po malte (obr. 7: 3). Z objektu bola odkrytá len vykurovacia čast’ (obr. 7: 2). Vzhladom na orientáciu hypokausta západo-východným smerom možno predpokladał', že obslužný priestor bol situovaný takisto v interiéri. Nad pecou sa dochoval jeden tehlový pás z roštu a v zásype objektu sa nachádzalo niekol'ko väčších, oblých kameňov, špinavých od sadzí (obr. 7: 2). Na korune muriva bol náznak d’alšej klenby nad úrovňou roštu (obr. 7: 2,4). Severná a východná stena pece mala zvonka v hornej časti súvislú vrstvu omietky, ktorá indikuje dobovú interiérovú pochôdznu úroveň (obr. 7: 3, 4). V dôsledku toho muselo zariadenie vystupovat' nad podlahu prízemného priestoru. V prípade, že by hypokaustum presahovalo výrazne vyššie, je možné uvažovat o vykurovaní priestoru na poschodí kláštora. Na základe stavebno-historického výskumu vieme, že už v najstaršej fáze mal kláštor aj nadzemné podlažie. Situáciu je tažké jednoznačne posúdit nakol'ko sa horná čast' pece nedochovala a nedisponujeme výškovými kótami. Túto

\footnotetext{
${ }^{21}$ B. Polla $(1986,143$ nn.) interpretoval komoru ako pec na prípravu jedla. Na základe stavebnej deštrukcie v zásype predpokladá, že mala po dlhšej osi valenú klenbu. Na výskumnej fotodokumentácii klenbu nemožno identifikovat’ ani v náznaku. Taktiež si treba uvedomit, že otvor do pece je situovaný v hrúbke obvodového muriva a nemohol byt prístupný z interiéru. Škridle v zásype komory môžu rovnako poukazovat na identifikáciu komory ako dymovodu.

${ }^{22}$ B. Polla $(1986,152,242)$ datuje pohárovité kachlice do 14. stor. a v iných priestoroch kláštora uvažuje o vykurovaní kachlovými pecami už od konca 13. stor. (Polla 1986, 237). R. Rusnák $(2009,105)$ pripúšta datovanie nádobkovitých kachlíc v prostredí Košíc až od 15. storočia.

${ }^{23}$ Ďakujem L. Kürthymu a B. Glockovej za poskytnutie výskumnej dokumentácie.

${ }^{24}$ Ďakujem P. Šimčíkovi za poskytnutie dokumentácie nálezu a možnost̉ jeho publikácie.
} 

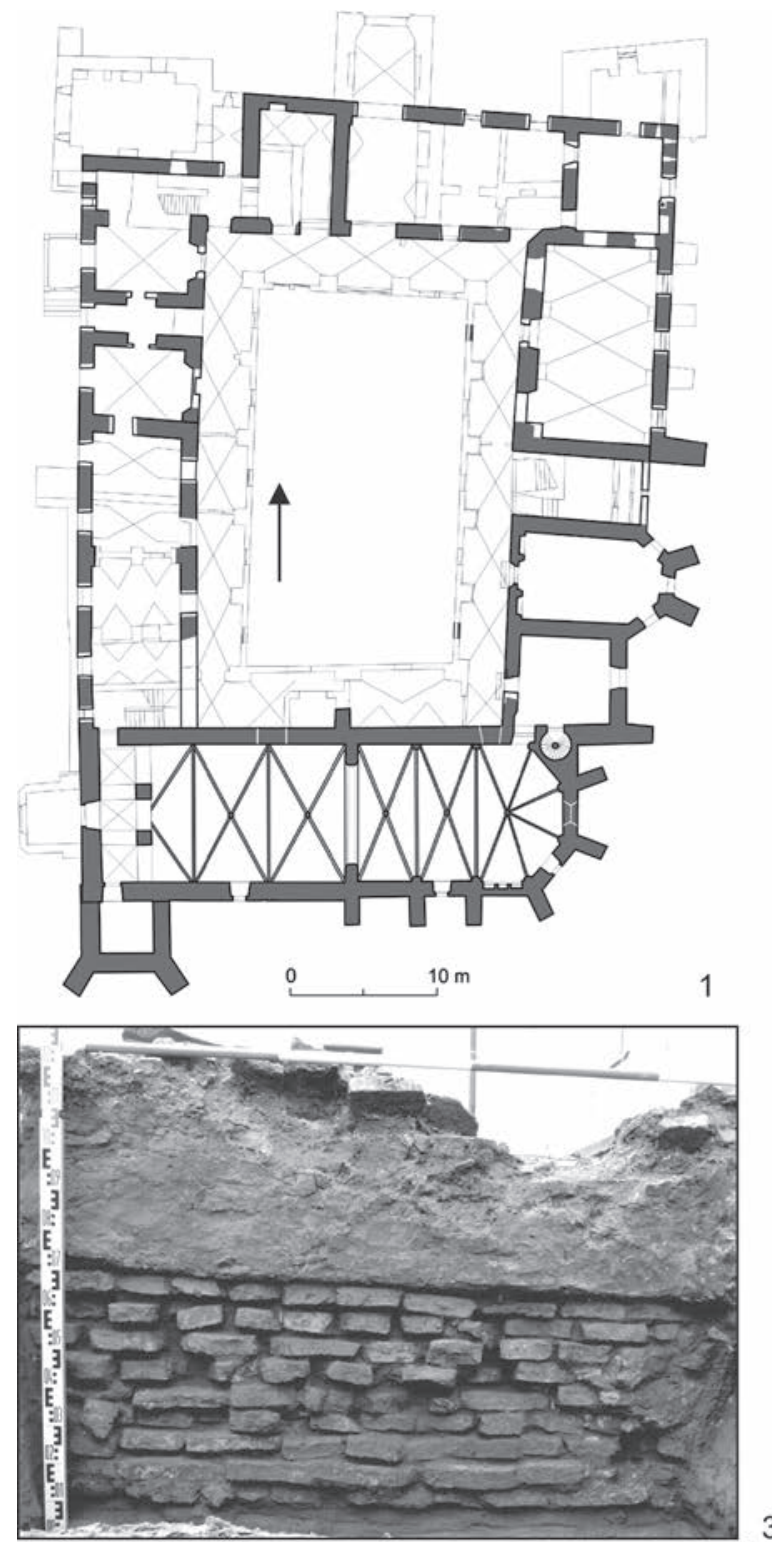

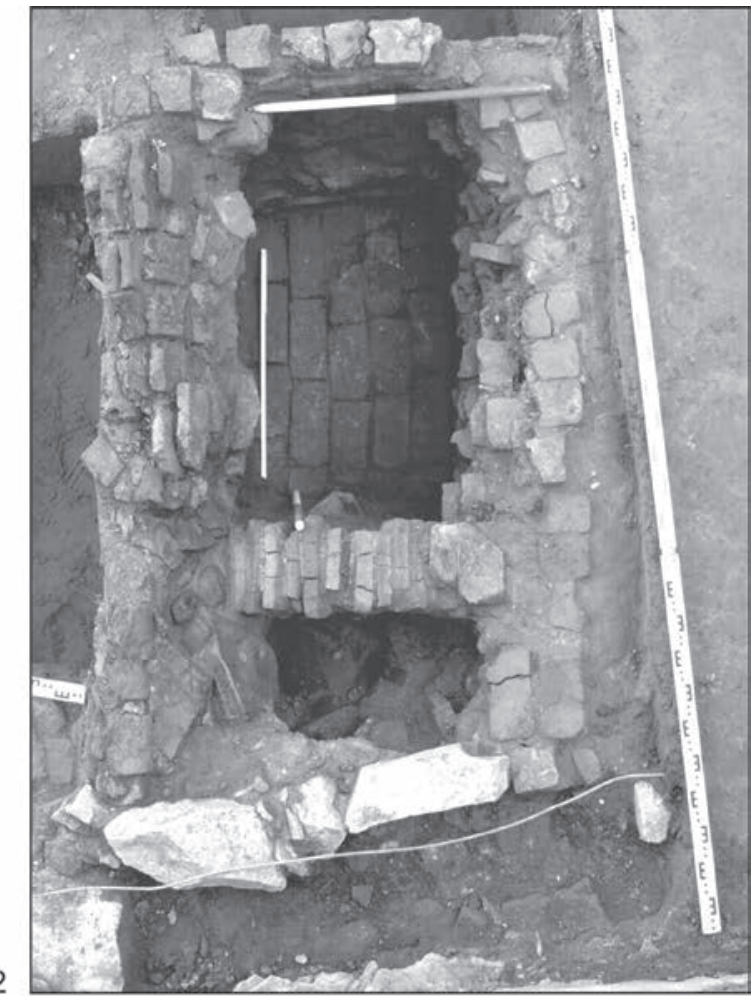

3

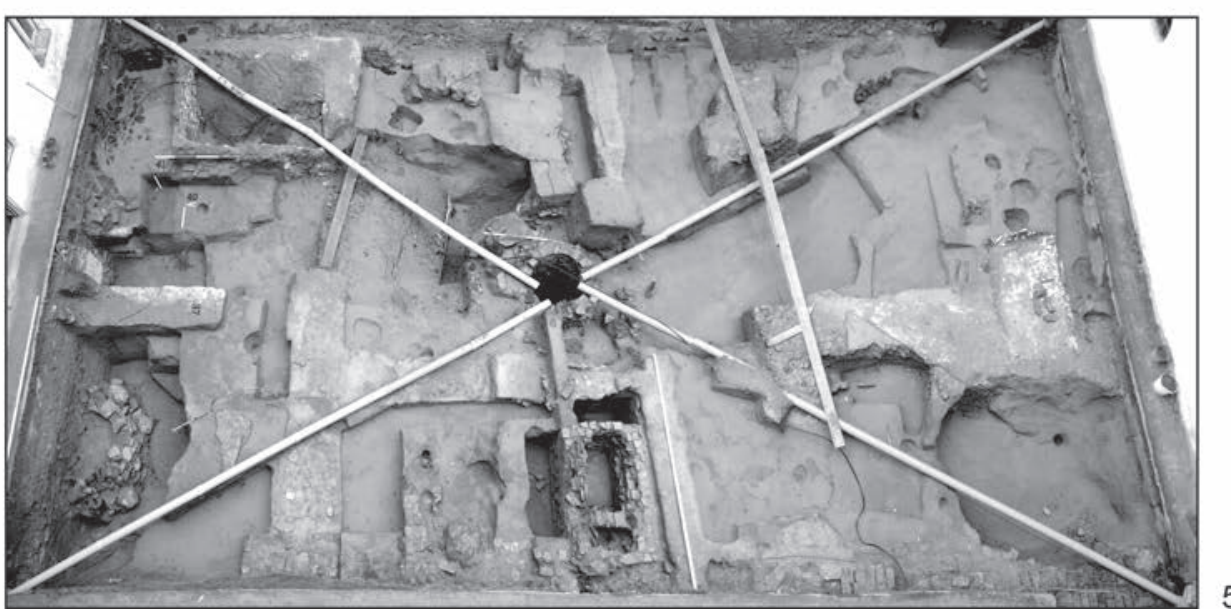

5

Obr. 7. Leles, kláštor premonštrátov. 1 - pôdorys kláštora s vyznačenými stredovekými murivami a približnou polohou pece (podla Pomfyová 2015); 2 - pohlad zhora na pec; 3 - pohlad na bočnú stenu pece; 4 - pohlad na zadnú stenu pece; 5 - celkový pohlad na nádvorie kláštora počas výskumu v rokoch 2013 a 2014 s vyznačenou polohou pece (2-5 autor P. Šimčík). 
alternatívu považujeme ale za menej pravdepodobnú pre zrejme pomerne výrazný výškový rozdiel zachovanej koruny pece a nadzemného podlažia. $\mathrm{V}$ prípade, že by zariadenie vykurovalo miestnost' na poschodí by bolo taktiež zbytočné jeho zahíbenie do terénu.

Na základe uvedených konštrukčných detailov usudzujeme, že ide o hypokaustum IV. typu. Zariadenie bolo situované v charakteristickej polohe pre refektár, resp. kalefaktorium. Vzhladom na prvú stavebnú fázu kláštora datovanú na prelom 13. a 14. stor. možno výstavbu pece datovat' najskôr od tohto obdobia. Sekundárny charakter použitých tehál by mohol naznačovat’ neskoršie obdobie vzniku. Z písomných prameňov vieme, že v kláštore sa uskutočňovali stavebné aktivity v priebehu druhej polovice 14. aj 15. stor., pričom na konci 15. stor. sa kláštor nachádzal v stave ruiny (Žažová 2018, 246-249, 261). Definitívny zánik zariadenia, ako aj celého severného traktu zrejme súvisel s predížením kláštora smerom na sever, čo sa podla stavebno-historického výskumu uskutočnilo na konci 15. až v prvej polovici 16. stor. (Kürthy/Glocková 2012). Existenciu zariadenia tak možno zasadit’ do rámca začiatku 14. stor. až konca 15. stor. Nález hypokausta, ako aj celý archeologický výskum sa spracúva a bude predmetom d’alších analýz, ktoré môžu načrtnutú tézu spresnit.

\subsection{Letanovce (Kláštorisko),} kláštor kartuziánov - zariadenie č. 1

Kartuziánsky kláštor na Skale útočišta v Letanovciach bol založený v roku 1299. V rokoch 1433 a 1454 ho vyplienili husiti a bratríci. Na prelome 15. a 16. stor. prešiel výraznou prestavbou. Jeho zánik spôsobil lúpežný prepad v roku 1543 (Slivka 1988; Slivka/Chalupecký 1995).

V kláštore boli identifikované dve teplovzdušné vykurovacie zariadenia (obr. 8: 1, 2). Prvé a staršie sa nachádzalo v stavbe situovanej pri južnom ramene vel'kej krížovej chodby (Slivka/Chalupecký 1995, 27 n.), vybudovanej $\mathrm{v} 14$. stor. (ústna informácia M. Slivka). Objekt mal rozmery $9 \times 6 \mathrm{~m}\left(54 \mathrm{~m}^{2}\right)$ a jedno nadzemné podlažie (obr. 8: 1-3). Hypokaustum sa nachádzalo na prízemí, ktoré bolo čiastočne zahíbené a zaklenuté valenou klenbou. Z objektu pochádza nález dvoch podlahových platní so vzduchovodmi (obr. 8: 5). Platne mali rozmery ? (40) x ? (40) x 13,5-14 cm. V ich strede bol otvor s priemerom 12 a $17 \mathrm{~cm}$, lemovaný žliabkom. Pec sa priamo neodkryla, pretože terén v interiéri stavby sa zo statických dôvodov neprehlboval. Objekt slúžil pravdepodobne ako refektár, možno kapitulná sieň. V budove na protilahlej strane krížovej chodby sa nachádzala kuchyňa. Vzhl’adom na dostupné údaje nie je možné stanovit typ hypokausta, do úvahy však prichádza najmä IV. typ. Jeho existenciu vieme zaradit taktiež len rámcovo do 14. až prvej polovice 16. stor.

\subsection{Letanovce (Kláštorisko),}

\section{kláštor kartuziánov - zariadenie č. 2}

Druhé teplovzdušné zariadenie na Kláštorisku sa nachádzalo v objekte situovanom na severnej strane malej krížovej chodby, oproti kostolu (obr. 8: 1, 2, 4). Stavbu pravdepodobne postavili až po roku 1500. Objekt bol poschodový a jeho nadzemné podlažie s trámovou podlahou mohlo taktiež slúžit ako spoločná jedáleň, čo by zodpovedalo tradičnej monastickej schéme. Prízemie tvorili tri miestnosti. Východná mala skladovaciu funkciu, stredná slúžila ako obytný priestor pre sakristiána, vykurovaný kachlovou pecou a v západnej sa mala nachádzat teplovzdušná pec (Slivka/Chalupecký 1995, 25). Jej bližší opis zatial' nebol publikovaný. V dôsledku toho sa k charakteru zariadenia nie je možné presnejšie vyjadrit'. Vzhladom na jeho stavebný kontext by malo fungovat v prvej polovici 16. stor., čo by predstavovalo jeden z vôbec najmladších exemplárov stredovekých teplovzdušných pecí. V tomto kontexte je zaujímavé, že pri prestavbe kláštora na prelome 15. a 16. stor. boli jeho objekty vybavené kachlovými pecami (Slivka 1988, 430, 433). Na vykurovanie spoločného, len príležitostne využívaného priestoru na poschodí stavby sa však mohli uplatnit', v tej dobe už zastaralé hypokaustum.

\subsection{Levoča, meštiansky dom (Námestie Majstra Pavla č. 31)}

Dosial' jediná pec na území Slovenska odkrytá v mestskom prostredí pochádza z Levoče (Urbanová 2003a, 84). ${ }^{25}$ Ide o meštiansky dom situovaný $\mathrm{v}$ juhovýchodnom rohu námestia Majstra Pavla (č. 31; obr. 9: 2). Na nález dodnes stojaceho zariadenia upozornil v literatúre F. Javorský (1990, obr. 24: 1-2 $)^{26}$ a meštiansky dom bol predmetom architektonicko-historického výskumu, ktorý na objekte identifikoval 10 stavebných fáz (Vlk/Sumbalová/Pichová 1979).

Do dnešnej podoby trojtraktového objektu sa dom postupne kreoval zo samostatne stojacej stavby v híbke parcely, situovanej cca $9 \mathrm{~m}$ od dnešnej uličnej čiary (obr. 9: 1). ${ }^{27} \mathrm{~V}$ najstaršej fáze, rámcovo datovanej do 14 . stor. až druhej štvrtiny 15. stor., išlo o jednopriestorový, dvojposchodový a podpivničený objekt s vnútornými rozmermi $9 \times 6,5 \mathrm{~m}\left(58,5 \mathrm{~m}^{2}\right) .{ }^{28}$ Stavba mala trámové stropy v nadzemnej časti aj v suteréne. K zmene uličnej čiary na námestí došlo pravdepodobne po roku 1431, kedy mesto vypálili husiti. Následne v druhej štvrtine až polovici 15. stor. (2. stavebná fáza) murovaný dom predížili po súčasnú uličnú čiaru a postavili, minimálne vo východnej časti, severný trakt domu. ${ }^{29}$ Najneskôr v rámci tretej fázy, datovanej do 60. rokov 16. stor., došlo k vzniku dodnes zachovanej trojtraktovej osnovy stavby a to zlúčením južného,

\footnotetext{
${ }^{25}$ Ďakujem M. Slivkovi za upozornenie na nález a G. Lukáčovi za pomoc pri jeho sprístupnení.

${ }^{26}$ Nálezy ani dokumentáciu z výskumu sa nepodarilo dohladat'. Za pomoc pri hladaní d’akujem P. Feckovi.

${ }^{27}$ Na základe analógií zo Saska je možné, že smerom k uličnej čiare predstupoval murovaný objekt drevený (zrejme starší) dom. U nás však na to zatial' chýbajú spol’ahlivé doklady (Oriško 2004).

${ }^{28} \mathrm{~V}$ literatúre sa tento typ domov uvádza niekedy ako vežový dom. Okrem primárnej obytnej funkcie na vyzdvihnutom prízemí sa na poschodí (v podkroví) predpokladá funkcia sýpky a kvôli výskytu štrbinových okien na niektorých stavbách sa nevylučuje ani ich obranná funkcia (Oriško 2004, 276).

${ }^{29}$ F. Javorský $(1990,81)$ datuje výstavbu domu do 14. stor. a jeho rozšírenie po uličnú čiaru kladie už na prelom 14. a 15. stor.
} 

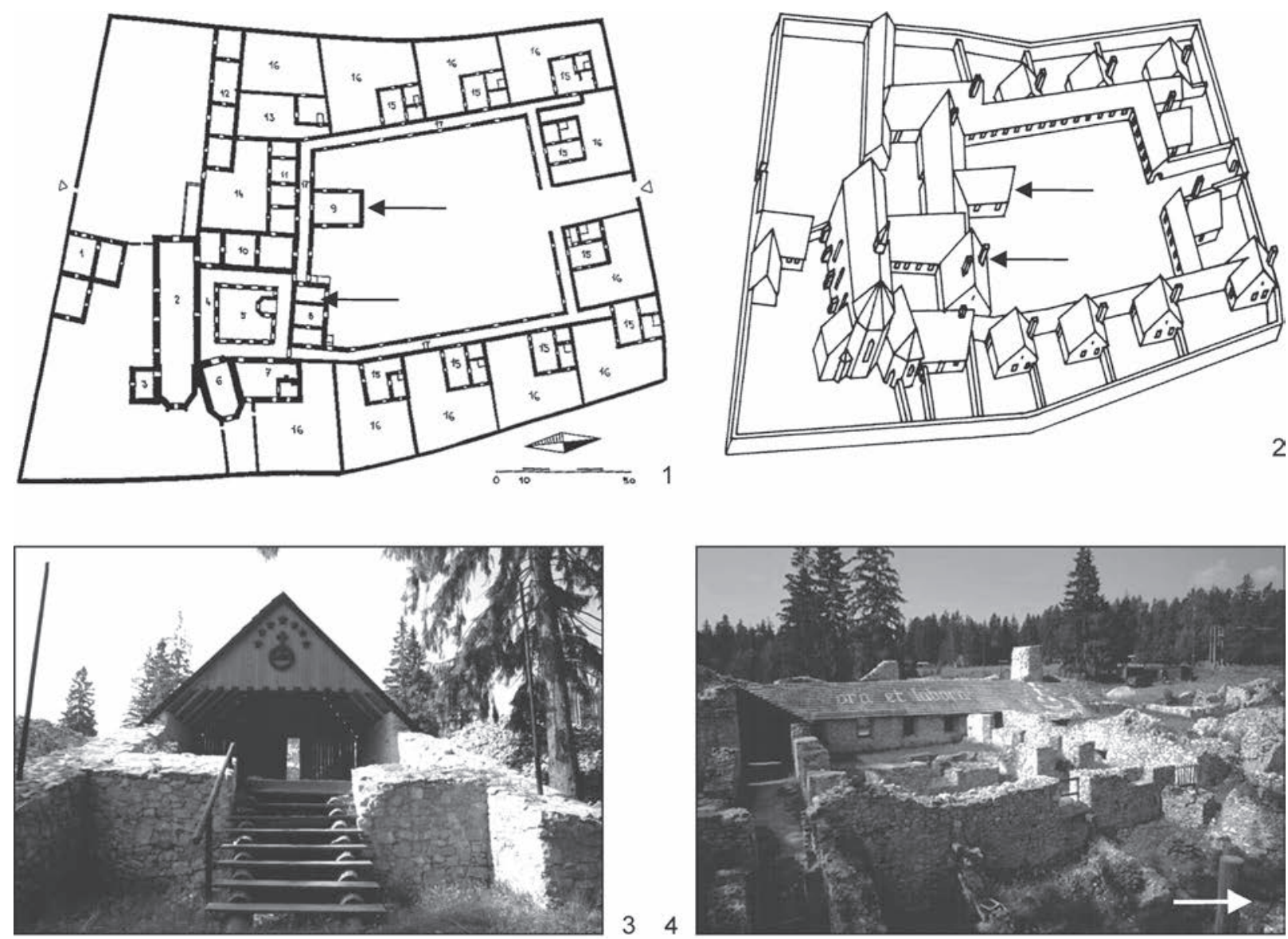

34
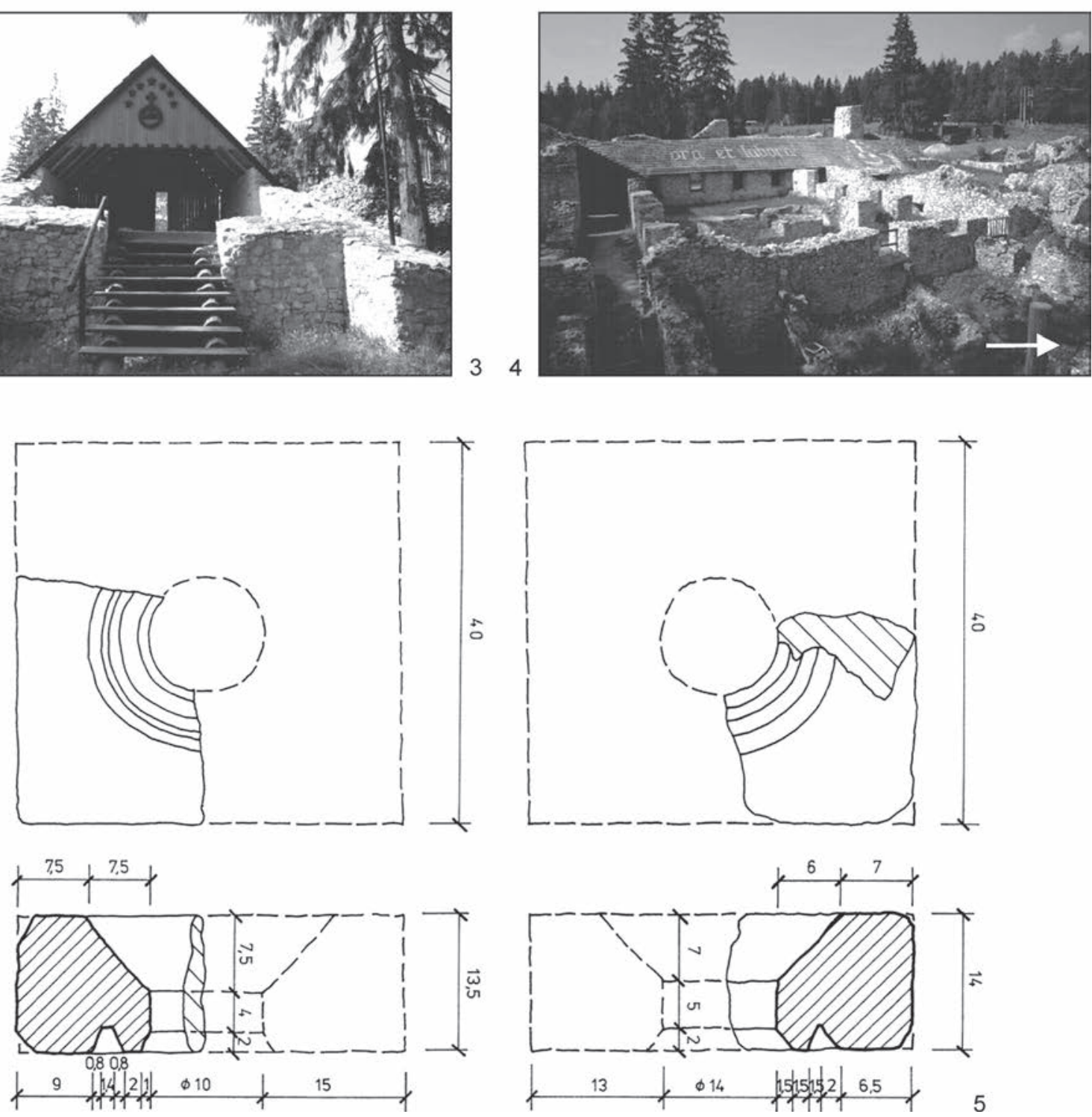

Obr. 8. Letanovce-Kláštorisko, kláštor kartuziánov. 1 - pôdorys kláštora s vyznačenou polohou pecí; 2 - ideálna rekonštrukcia kláštora s vyznačenou polohou vykurovaných objektov (1, 2 podla Slivka/Chalupecký 1995); 3 - vykurovaný objekt pri vel'kej krížovej chodbe; 4 - vykurovaný objekt pri malej krížovej chodbe s vyznačenou polohou pece; 5 -fragmenty podlahových platní so vzduchovodom (autor M. Slivka). 

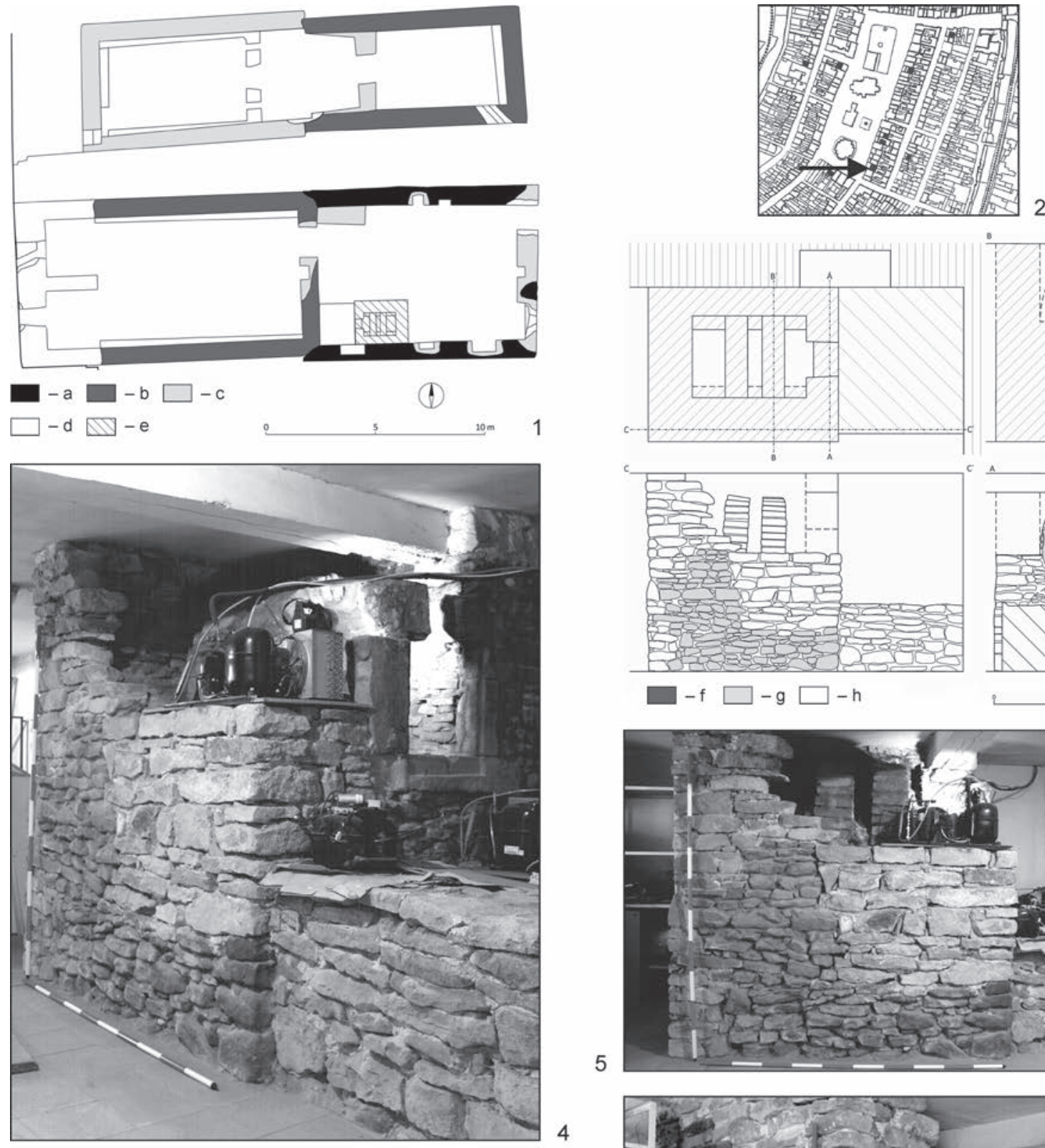

\section{(1)}
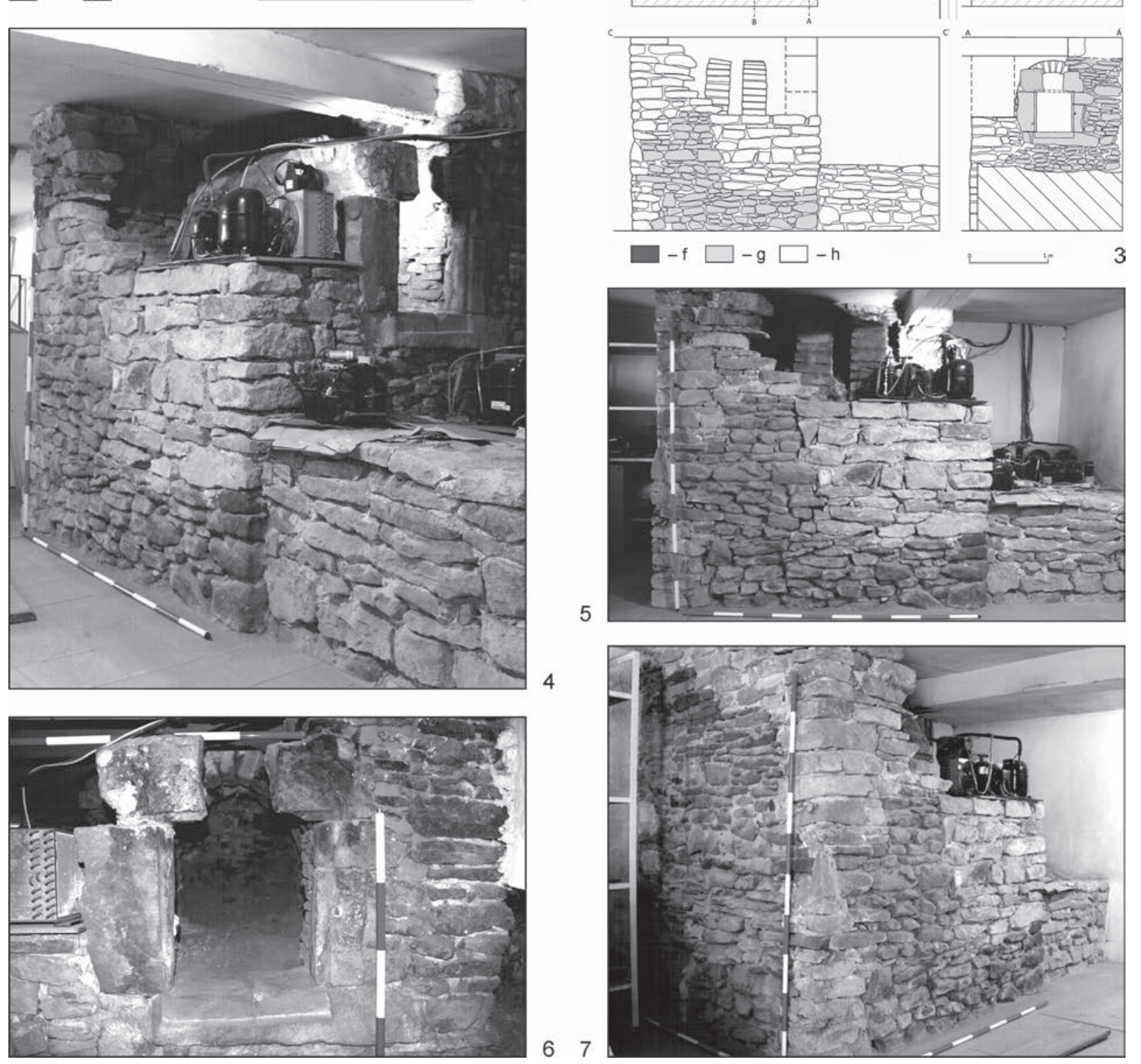

Obr. 9. Levoča, Majstra Pavla č. 31, meštiansky dom. 1 - pôdorys suterénu domu (podl’a Vlk/Sumbalová/Pichová 1979); 2 - situácia mestského jadra s vyznačenou polohou pece (podla Oriško 2004); 3 - pôdorys, priečny rez, bočný a čelný pohlad na pec; 4 - pohlad spredu na pec; 5 - bočný pohlad na pec; 6 - detail na vstup do pece; 7 - pohlad zozadu na pec. Legenda: a - pred druhou štvrtinou 15. stor.; $\mathrm{b}$ - polovica 15. stor.; c - 60. roky 16. stor.; $\mathrm{d}$ - novovek; e - pec; $\mathrm{f}$ - tehla; $\mathrm{g}$ - pôvodné kamenné murivo; $\mathrm{h}$ - sekundárne murivo. 
a severného objektu a pridaním prejazdu. ${ }^{30}$ Dom v tejto fáze získal tretie nadzemné poschodie a architektonický výskum v stavebnej hmote identifikoval prvý raz použitie tehly. Na základe malty zaradil výskum do tejto etapy aj výstavbu hypokausta, ktoré však identifikoval ako „operák komínov" (Vlk/Sumbalová/Pichová 1979, 85).

Vykurovacie zariadenie bolo situované v suteréne južného traktu, pri juhozápadnom nároží východnej miestnosti, t. j. v najstaršej časti domu (obr. 9: 2). Hypokaustum tu pristavali $\mathrm{k}$ južnej stene domu, pričom sčasti prekryli staršiu niku (rozmery: 46 x 108,5 x $70 \mathrm{~cm}$ ). Pec mala obdížnikový tvar s vonkajšími rozmermi 1,93 x 2,37 m (obr. 9: 3). Zariadenie siahalo od podlahy po strop suterénu, so zachovanou výškou muriva $2,47 \mathrm{~m}$, pričom treba počítał s tým, že pôvodne vystupovalo o niečo vyššie nad úroveň trámovej podlahy prízemia (obr. 9: 4).

Vykurovacia komora pece mala svetlost' 1,02 x 1,42 m a dochovanú výšku 0,96 m (obr. 9: 3). Situovaná bola 1,27 m nad podlahou suterénu. Po stranách komory sa nachádzal vo výške $0,23 \mathrm{~m}$ od jej dna sokel široký cca 0,14-0,17 m, na ktorom bol osadený rošt pece (obr. 9: 3). Ten tvorili dva tehlové klenuté pásy, vysoké cca $0,90 \mathrm{~m}$ a široké $0,28 \mathrm{~m}$. Zachovaný rošt však predstavuje rekonštrukciu vyhotovenú zo sekundárne použitých novovekých tehál. Z pôvodného roštu sa v spodnej časti oboch pásov zachovali len po tri tehly s rozmermi $28,3-29,6 \times 8 \times 13,5 \mathrm{~cm}$. Dno pece bolo takisto vyhotovené $\mathrm{z}$ tehál a na vrchu pece F. Javorský (1990, 81) identifikoval lôžko pre kamennú platňu.

Steny vykurovacej komory niesli stopy po sadziach, ktoré sa koncentrovali v hornej juhozápadnej časti pece, čo naznačuje, že v týchto miestach sa nachádzal komín. Jeho torzo na južnej obvodovej stene domu, v úrovni prvého nadzemného podlažia, zachytáva fotodokumentácia $F$. Javorského (1990, 81, obr. 24: 1). Stavebno-historický výskum uvádza na druhom podlaží v rovnakej časti domu stopy po vykurovaní a predpokladá tu krb, datovaný do rovnakej stavebnej fázy (Vlk/Sumbalová/Pichová 1979, 86).

Na čelnej západnej stene pece sa nachádzal vstup (51 x $45 \mathrm{~cm}) \mathrm{s}$ ostením vyhotoveným $\mathrm{z}$ piatich opracovaných kamenných článkov (obr. 9: 3, 6). Ostenie malo po obvode na okraji profilovaný ústupok pre dvere $(61 \times 50 \mathrm{~cm})$. Tie sa pravdepodobne otvárali na pravej strane, čo dokladá torzo železnej skoby. Na lavej strane ostenia, v spodnej časti, je obdížnikový zásek, ktorý zrejme slúžil na osadenie pántov.

Hypokaustum bolo obsluhované zo suterénu. Pred vstupom do pece v nároží miestnosti je situovaná sekundárne pristavaná vyzdvihnutá plošina, zlepšujúca prístup $\mathrm{k}$ peci (obr. 9: 3, 5). Stavebno-historický výskum ju datuje až do druhej polovice 18. stor. Prístavba bola trochu užšia ako hypokaustum s rozmermi 1,82 x 1,56 m a výškou $0,85 \mathrm{~m}$.

Dodnes zachované a stojace vykurovacie zariadenie prešlo v minulosti pomerne výraznou rekonštrukciou. Pôvodná architektúra objektu bola vyhotovená z opracovaných, niekedy plochých kvádrov (max. $44 \mathrm{~cm}$ ) a menších lomových kameňov, kladených v nepravidelných riadkoch. Ako spojivo bola v obvodových stenách použitá malta. Vo vnútri vykurovacej komory spájala murivo hlina prepálená do červena. Takéto použitie spojív je dobre viditelné aj na čelnej stene pece (obr. 9: 6). Počas rekonštrukcie zariadenia, ktorá sa realizovala po výskume F. Javorského (r. 1988), boli obnovené časti obvodových stien, rošt a zrejme aj prístavba $\mathrm{v}$ predpecnom priestore. Doplnené murivo bolo vyhotovené z väčších kvádrov (max. $62 \mathrm{~cm}$ ), spájaných odlišnou svetlejšou maltou (obr. 9: 3-5, 7).

Na základe konštrukcie prirad’ujeme hypokaustum k IV. typu. Datovanie, ktoré navrhol stavebno-historický výskum t. j. 60. roky 16. stor., považujeme za neskoré. Isté je, že jeho konštrukcia nebola súčastou prvej stavebnej fázy, pretože objekt je sekundárne pristavaný k obvodovej stene domu. F. Javorský $(1990,81)$ datoval výstavbu domu do 14. stor. Počiatky meštianskych murovaných domov na Spiši, situovaných v híbke parciel, sa datujú od 14. stor. (Oriško 2004, 279) a nové dendrodáta z Levoče potvrdzujú ich výstavbu už v prvej štvrtine 14. stor. (ústna informácia M. Stejskal 2021). Na základe dostupných údajov predpokladáme konštrukciu pece medzi prvou až druhou stavebnou fázou, t. j. medzi 14. až polovicou 15. stor.

Problematická je otázka ukončenia funkčnosti zariadenia, ktorá súvisí s problémom datovania jeho rekonštrukcie. Publikovaná fotodokumentácia z výskumu F. Javorského paradoxne zachytáva kompletne stojaci rošt pece, avšak nakol'ko to umožňuje identifikovat zlá kvalita snímku, zároveň aj deštruovaný plášt hy pokausta, ktorý nezodpovedá dnešnému stavu. To by znamenalo, že k rekonštrukcii došlo, aspoň sčasti, až po archeologickom výskume (r. 1988). Na druhej strane v prípade, že záber zachytáva rošt totožný s dnešným, možno oprávnene vyslovit domnienku o využívaní zariadenia dlho do novoveku. Poukazujú na to použité novoveké tehly, ktoré nesú aj stopy po sadziach. Takúto možnost' naznačuje aj datovanie prístupovej plošiny k peci, ktorú stavebno-historický výskum zaradil do druhej polovice 18. stor. F. Javorský $(1990,81)$ uvádza v zásype pece fragmenty novovekých kachlíc zo 16. až 17. stor. Dlhodobé používanie pece by mohlo byt’ dôvodom toho, prečo sa zariadenie zachovalo dodnes.

V kontexte ostatných stredovekých meštianskych domoch v Levoči sa javí, že používanie hypokausta bolo skôr výnimkou. Počas stavebno-historických výskumov tu boli v iných domoch identifikované rohové kuželovité dymníky a kozuby na kamenných konzolách. Vybavené nimi boli tak domy, ktoré sa nachádzali na námestí Majstra Pavla (č. 11, 25,37, pravdepodobne aj č. 26; ústna informácia G. Lukáč), ako aj v iných častiach mesta (Košická č. 16, Hviezdoslavova č. 22; Oriško 2004, 269).

\subsection{Levoča, meštiansky dom (Námestie Majstra Pavla č. 40)}

Ďalší nález z meštianskeho prostredia pochádza rovnako z Levoče z Námestia Majstra Pavla č. 40 (obr. 10: 1). Ide o trojtraktový patricijský dom s prejazdom, ktorý sa kreoval od 14. stor. pôvodne z dvoch samostatných objektov (obr. 10: 2; Husovská/Urbanová/Kosová 2016). V roku 2015 sa vo východnom nároží v zadnom dvore domu pri zemných prácach na odvlhčení objektu našiel fragment kamennej podlahovej platne so vzduchovodom $(10: 2,3){ }^{31}$ Nález dokladá prítomnost' teplovzdušnej pece, ktoré mohla

\footnotetext{
${ }^{30}$ Príčinou prestavby objektu mohol byt’ požiar mesta v roku 1550. V dôsledku neho zanikol aj archív mesta. Majitelov domu poznáme až z nasledovného obdobia. Prvý známy je Jakub Wassrleiter (1542-1551), po ktorom nasledovala devätročná cezúra. Novým vlastníkom domu (od roku 1560) sa stal Sebastian Sohney (Vlk/Sumbalová/Pichová 1979, 72n.).

${ }^{31}$ Ďakujem M. Stejskalovi za upozornenie na nález a poskytnutie jeho dokumentácie.
} 

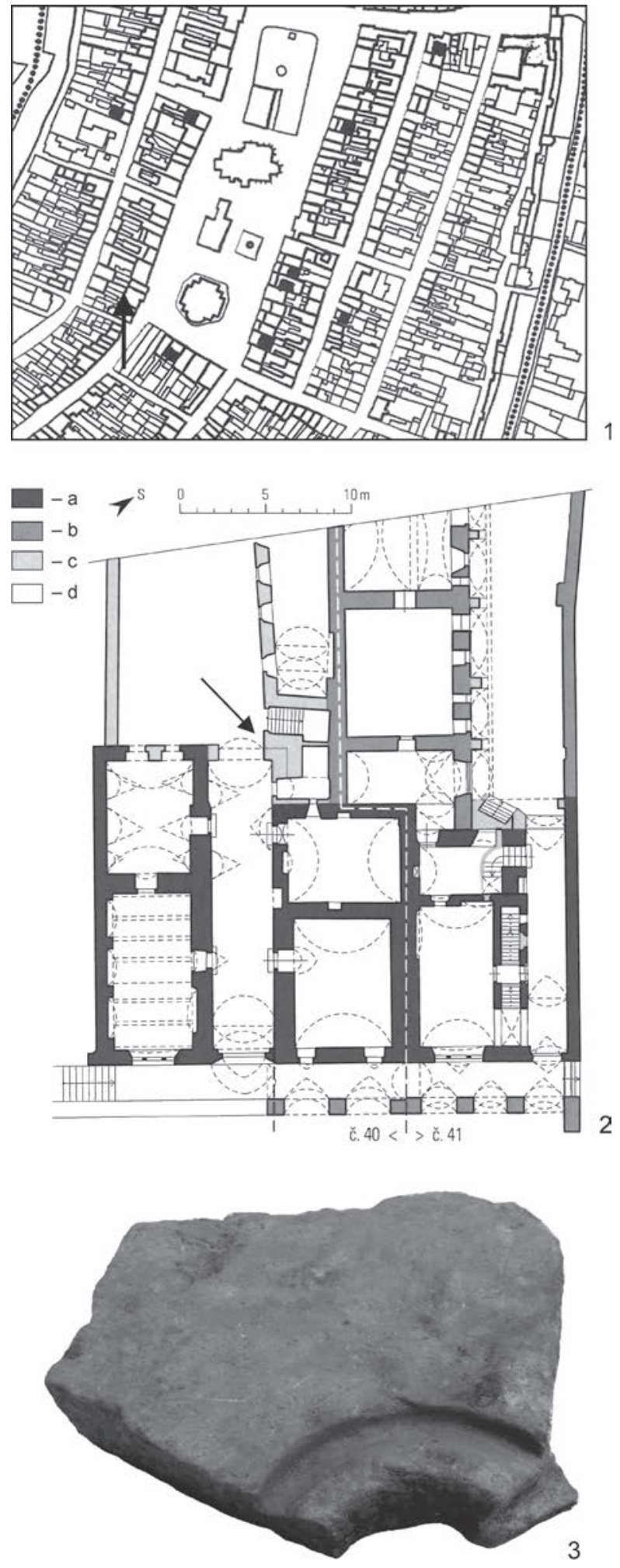

Obr. 10. Levoča, Majstra Pavla č. 40, meštiansky dom. 1 situácia mestského jadra s jednopriestorovými domami a vyznačenou polohou nálezu platne (podl’a Oriško 2004); 2 - pôdorys prízemia domu s vyznačenou polohou nálezu platne (podla Husovská/Urbanová/Kosová 2016); 3 - fragment podlahovej platne (autor M. Stejskal). Legenda: a - 14. stor.; $\mathrm{b}-15$. stor.; $\mathrm{c}-16$. -17 . stor.; $\mathrm{d}$ - druhá polovica 18. stor. vykurovat’ severný, alebo južný trakt stavby. Vzhl’adom na absenciu d’alších informácií možno podla stavebného vývoja len rámcovo usudzovat', že išlo o pec z 14. až 15. stor., zrejme IV. typu.

\subsection{Ludanice, kláštor benediktínov}

Benediktínsky kláštor $\mathrm{v}$ Ludaniciach pravdepodobne založil na prelome 12. a 13. stor. rod Ludanickovcov. Prvá písomná zmienka jeho existenciu zachytáva až v roku 1327. Rehol'ný život v Ludaniciach zanikol najneskôr v prvej polovici 16. stor., pričom pramene jeho úpadok indikujú už v roku 1485. V rokoch 2005 až 2007 sa na lokalite realizoval archeologický výskum, ktorý odkryl južné krídlo a čiastočne zachytil nárožie východného krídla kláštora (Hanuš 2018; Hanuš/Kušnirák 2014).

Hypokaustum bolo umiestnené v južnom krídle v rámci ktorého sme identifikovali tri priestory. Nachádzalo sa v západnej, najväčšej miestnosti s rozmermi 9,66-10,13 x $5,81 \mathrm{~m}\left(57,45 \mathrm{~m}^{2}\right)$, ktorú identifikujeme ako refektár (obr. 11: 1). Zariadenie bolo situované v juhovýchodnom nároží, pričom východná priečka miestnosti, ako aj južný obvodový múr kláštora ho prekrývali (obr. 11: 1, 2, 5). Toto pozorovanie naznačuje, že južné krídlo kláštora a hypokaustum boli postavené počas jednej stavebnej fázy. Poukazuje na to aj použitý rovnaký stavebný materiál - plevové tehly (k tehlám: Curný/Gregor/Hložek 2018; Čurný/Hložek 2007).

Pec má mierne nepravidelný obdížnikový tvar, pričom jej pozdížna os je vychýlená o $4^{\circ}$ na sever. Zariadenie je dlhé $2,77 \mathrm{~m}$ a široké $1,75 \mathrm{~m}$ a v najzachovalejšej časti má výšku 2,17 m. Vnútro pece má rozmery 1,93-2,17 x $0,72-1 \mathrm{~m}$. Jednotlivé steny majú nasledovnú šírku: severná 0,44-0,61 m, západná $0,44-0,57 \mathrm{~m}$, východná $0,26-0,49 \mathrm{~m}$ a južná $0,31 \mathrm{~m}$. S výnimkou južnej steny sa všetky ostatné mierne zbiehajú dovnútra pece. $Z$ bočných stien vychádza vo výške 0,68 m od dna rímsa, o ktorú bol opretý dnes už nezachovaný rošt pece (obr. 11:3, 4, 6). V zásype zariadenia sa nachádzali zadymené riečne kamene. Pec vystupovala minimálne 0,21 m nad identifikovanú dlážku kláštora. Podlahové platne prekrývajúce pec sa nenašli, rovnako sa nepodarilo počas výskumu zistit’ spôsob odvodu splodín. Stopy od dymu v peci boli čitatel'né najmä nad opornými rímsami roštu. Dno pece ležalo cca 1,9-2 m pod dlážkou kláštora a vyhotovené bolo len z prepáleného sprašového podložia (obr. 11: 4, 6).

Z juhu sa na pec pripájal krátky prístupový koridor umiestnený v línii s východnou stenou (obr. 11: 2, 3). Koridor má dĺžku 0,88 m, šírku 0,50 m a výšku 0,82 m a je zaklenutý valenou klenbou. Pec aj s koridorom má celkovú dížku 3,49 m.

Pec bola vymurovaná z plevových tehál s priemernými rozmermi 24,9 x 11,7 x 5,1 cm (Čurný/Hložek 2007, 69). Nad roštom v hornej časti pece tehly uložili v riadkovanej väzbe ako väzáky. Kladenie pritom nemalo pravidelný systém styčných škár. Pod úrovňou roštu použili krížovú väzbu, striedajúcu rad väzákov a rad behúňov. Na bočných stenách pece krížovú väzbu využili aj o čosi vyššie nad roštom. Tehly boli spájané hlinou, ktorá bola prepálená do červena. Malta bola použitá len na vstupnej južnej stene. Na nej sa na vnútornom líci nachádzali aj zvyšky hrubšej prepálenej hlinitej omietky (obr. 11: 4).

Zjuhu sa k peci pripájal obslužný priestor (obr. 11: 1, 3, 5), ktorý mal formu smerom nadol sa zužujúcej poloválnej jamy. Dno obslužného priestoru ležalo 1,9-2 m pod 


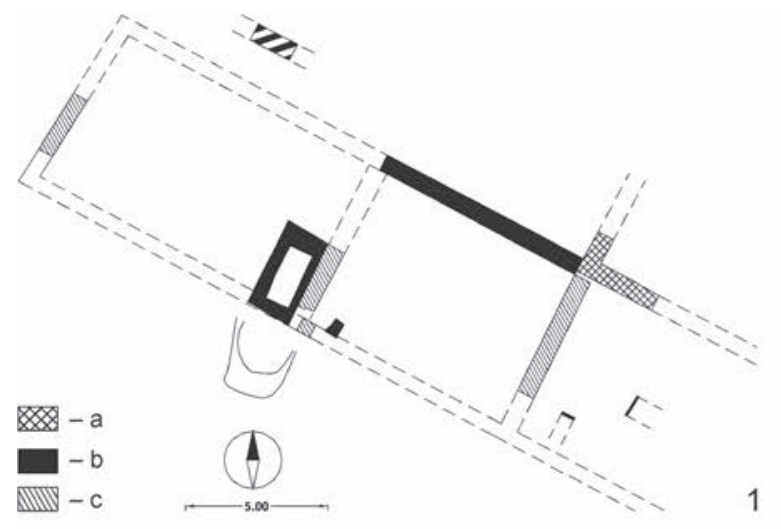

2
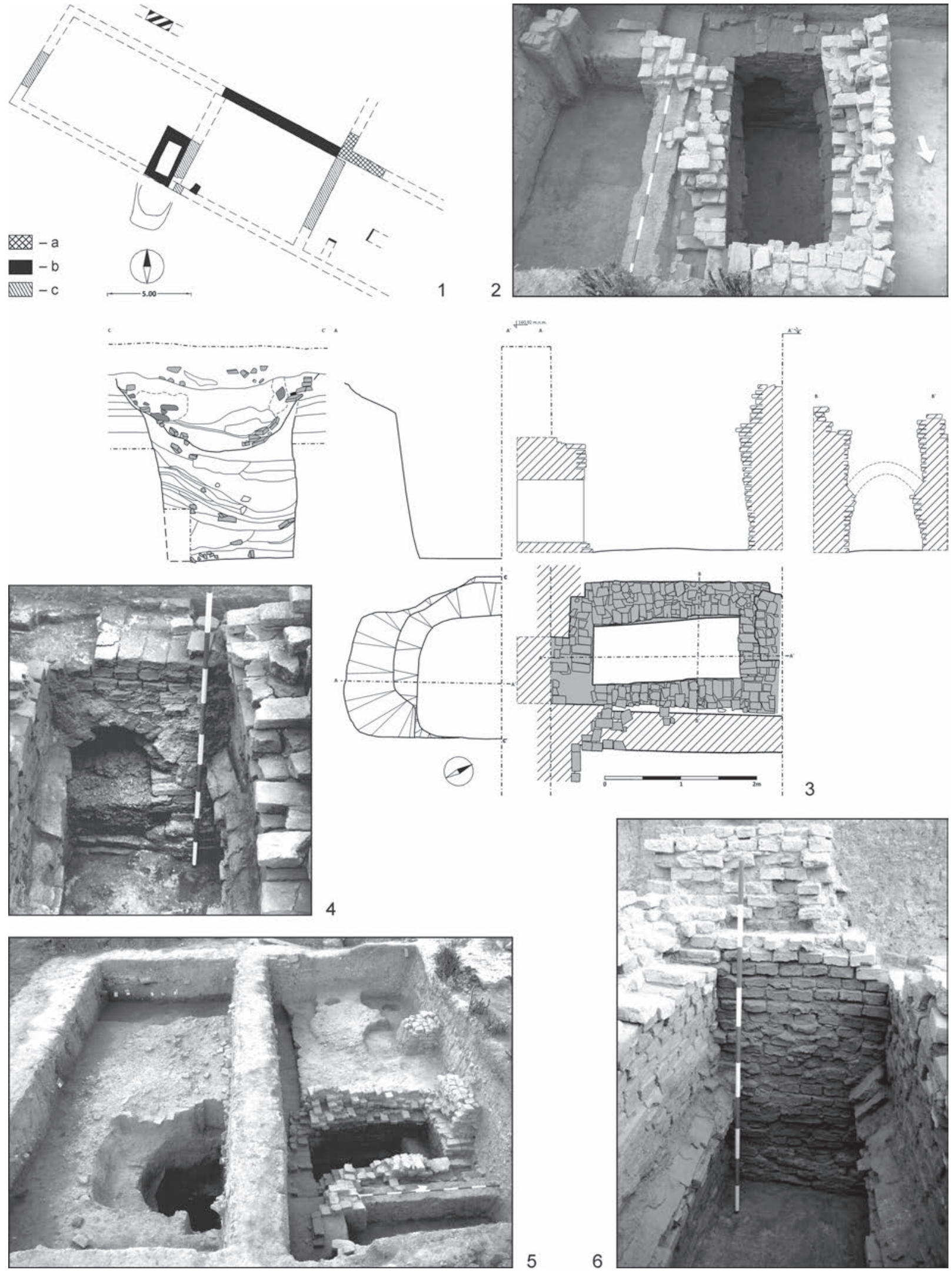

Obr. 11. Ludanice, kláštor benediktínov. 1 - plán kláštora s nálezom pece; 2 - pohlad zhora na pec; 3 - pôdorys, pozdížny a priečny rez zariadením a stratigrafia zásypu obslužného priestoru; 4 - detail vstupného otvoru a dná pece so stopami popola; 5 - pohl’ad na južné krídlo kláštora s pecou v interiéri a obslužným priestorom v exteriéri; 6 - pohl’ad do vnútra pece. Legenda: a - východné krídlo, 1. fáza; b - južné krídlo, 2. fáza, prvá polovica 14. stor.; c - negatív múra. 
exteriérovou dlažbou. Jama bola na juhu rozšírená o plytký predstupeň, ktorý mohol slúžit na lepší prístup k šachte. ${ }^{32}$ Obslužný priestor bol po vstupný koridor, ktorý vyústoval približne v jeho osi, dlhý 2,28 m. Celková dížka hypokausta aj s obslužným priestorom bola 5,76 m.

Ludanické hypokaustum zarad’ujeme podla typológie K. Bingenheimera (1998) k IV. typu. Zo zásypu pece pochádza keramika z konca 12. až prvej polovice 15. stor. a našli sa tu tri mince. Pri dne pece ležal viedenský fenig z konca 14. stor. (určil J. Hunka), v najmladšom zásype obslužného priestoru bol denár Ludovíta I. z rokov 1373-1382 (určil M. Budaj) a pri okraji obslužného priestoru, na rozhraní zánikového horizontu kláštora, sa našiel fenig Albrechta II. z rokov 1330-1358 (určil M. Budaj). Výstavbu hypokausta datujeme na základe typológie, stratigrafických vztahov a sprievodných nálezov do prvej polovice 14. stor. Zánik zariadenia ako aj odkrytého južného krídla kláštora sa udial zrejme už v druhej polovici 14. až prvej polovici 15. stor.

\subsection{Nemešany (Zalužany), panský dvorec}

Zaniknutá osada Zalužany ležiaca v katastri Nemešian (poloha Koscílek) bola majetkom drobnej spišskej šlachty. Jej obnovenými majitel’mi sa po tatárskom vpáde stali bratia Vlk a Čakan, ktorí od Bela IV. obdržali v roku 1255 donáciu, za čo mali slúžit ako spišský kopijníci. Ich spoločný majetok sa začal už od roku 1262 postupne delit’ a v roku 1413 sa majitelom takmer celých Zalužian stala Spišská kapitula. Osada aj s panským dvorcom zanikli niekedy po polovici 15. stor., pričom v roku 1475 túto skutočnost’ zachytávajú už písomné pramene (Polla 1962, 152-157).

Na lokalite realizoval v rokoch 1955 až 1957 B. Polla výskum, ktorý odkryl kostol a panský dvorec (obr. 12: 1, 2), samotná osada skúmaná nebola. Základ dvorca tvorila obytná veža, ktorá tu stála najneskôr na konci 13. stor. B. Polla celkovo identifikoval 4 stavebné fázy, pričom finálnu podobu mal dvorec nadobudnút najneskôr koncom 14. stor. (obr. 12: 3). V rámci tretej stavebnej fázy bola obytná veža rozšírená o tri priestory. Najväčší z nich (č. V) mal štvorcový pôdorys s rozmermi 5,7 x 5,7 m (32,49 m²) a bol pristavaný k veži zo západnej strany. Jeho súčastou bola $\mathrm{v}$ juhovýchodnom rohu na prízemí osadená pec, ktorú identifikujeme ako hypokaustum. Zariadenie bolo prístupne a obsluhované z exteriéru (obr. 12: 3, 6; Polla 1962, 45, 47, 59-63, 71, 74-77, 95, 96).

Pec mala obdĺžnikový tvar s vonkajšími rozmermi $2 \mathrm{x}$ 2,1 m a vnútornou svetlostou 1,6 x 1,07 m. ${ }^{33}$ Vymurovaná bola $z$ vel'kých riečnych kameňov spájaných maltou. Zo severnej a západnej strany, t. j. z interiéru miestnosti, ju obmurovali lomovým kameňom (obr. 12: 5). Južná stena pece bola deštruovaná takmer po dno a lemovala ju obvodová stena budovy oddelená zretelnou cezúrou (obr. 12: 6, 7). Dno mala pec vydláždené riečnymi kameňmi a vymazané 10 až $20 \mathrm{~cm}$ vrstvou prepálenej hliny. Zariadenie bolo pôvodne zaklenuté po dlhšej osi na čo poukazoval zachovaný nábeh klenby na severnom múre. V južnej stene mala pec vyformovaný ústupok zrejme naznačujúci polohou dymovodu (obr. 12: 3). Vstup do hypokausta sa nachádzal na východnej strane, orientovaný do exteriéru, pričom ležal vo výške $0,6 \mathrm{~m}$ nad úrovňou dvora. Otvor bol široký $50 \mathrm{~cm}$ a lemovali ho opracované pieskovcové články (obr. 12: 4, 8). Prah mal rozmery $10 \times 10 \times 86 \mathrm{~cm}$ a bočné ostenia ? (40) x 15 x 15 cm. Kamenné články mali na okraji po obvode profilovaný ústupok pre dvierka. V l’avom ostení bol $10 \mathrm{~cm}$ nad prahom vyhlbený otvor slúžiaci na ukotvenie, prípadne uzatváranie dvierok. Priestor v exteriéry pred pecou bol pravdepodobne prekrytý drevenou strieškou. Poukazujú na to zhorené trámy nájdené 1 až $2 \mathrm{~m}$ od pece na úrovni dvora. V zásype zariadenia sa nachádzala stavebná sutina obsahujúca aj silne prepálené okruhliaky. Okrem toho sa tu našli aj rôzne hnutel'né nálezy datované do 14. a 15. stor. (Polla 1957, 115-119; 1962, 61, 64-66).

Pec bola postavená súčasne $\mathrm{s}$ miestnostou $\mathrm{V}$ v rámci tretej stavebnej fázy datovanej do druhej polovice 14. stor. Z priestoru pochádzajú okrem iného nálezy dvoch mincí Ludovíta I. (1342-1382), z toho jedna sa našla v spálenej vrstve tesne pod podlahou miestnosti (Polla 1962, 61, 95). B. Polla $(1962,62)$ miestnost č. V interpretoval ako kuchyňu vzhl'adom na nález ohniska, resp. krbu v severovýchodnom rohu.

V priestore obytnej veže a pri západnej stene miestnosti č. V sa našli kamenné platne s otvorom uprostred (Polla 1962, 50, 61). B. Polla ich interpretoval ako „akési dlaždice, v ktorých sa mohli otáčat dvere“. Publikované zábery ich žial' nezobrazujú v dostatočne čitatel'nom detaile (Polla 1962, obr. 42; 46). Na základe dostupného opisu, pričom v jednom prípade sa okrem otvoru uvádza aj žliabok, išlo podla nášho názoru s vel'kou pravdepodobnostou o podlahové platne z hypokausta. Exemplár z veže mal pomerne vel'ké rozmery $66 \times 88 \times 9 \mathrm{~cm}$, čo je porovnatel'né napr. s rozmermi podlahovej platne zo Spišského Štiavnika.

B. Polla (1957; 1962, 64-66) k nálezu pece nepoznal analógiu a interpretoval ju ako pec na pečenie chleba. Vykurovaciu funkciu zariadeniu nepripisoval, nakol'ko sa v miestnosti č. V nachádzalo ešte ohnisko, resp. krb, ktorý mohol plnit' aj vykurovaciu funkciu. Forma a rozmery pece, nález okruhliakov, ako aj pravdepodobných podlahových platní spolahlivo dokladá, že išlo o teplovzdušnú vykurovaciu pec IV. typu, s čím dobre koreluje aj B. Pollom navrhované datovanie zariadenia do druhej polovice 14 . stor.

Na skutočnost', že sa v miestnosti č. V nachádzalo aj iné vykurovacie teleso naša interpretácia nenaráža, nakol'ko hypokaustum vyhrievalo priestor na poschodí. Tento záver ale koliduje s navrhovanou rekonštrukciou pevnôstky, ktorá v tejto časti predpokladá len prízemné podlažie (obr. 12: 2). Domnievame sa, že správnejšie tu bude počítat’ aj s poschodím. Poukazovat' na to môže aj fakt, že miestnost’ č. V bola zasypaná stavebnou deštrukciu a prepálenou hlinou do híbky $2 \mathrm{~m}$, pod ktorou sa nachádzala aj cca $20 \mathrm{~cm}$ vrstva spálených stropných trámov (Polla 1962, 62).

Hypokaustum v Nemešanoch je zaujímavé tým, že jeho obslužný priestor sa nachádzal v otvorenom exteriéry. Ide o pomerne zriedkavé riešenie, poznáme k nemu však analógie. Stretávame sa s ním napr. vo vidieckej šlachtickej rezidencii v Kisnána zo 14. stor. (Buzás 2012; Nagy 2009; 2011, 85 n.; Pámer 1970; 1998), alebo v dominikánskom kláštora v Budíne zo začiatku 15. stor. (H. Gyürky 1981, 42 n., 46, 99-102). Za zmienku stojí tiež skutočnost', že z dvorca nie sú doložené žiadne nálezy kachlíc.

\footnotetext{
32 Predstupeň môže byt๋ aj dôsledok sekundárneho zásahu.

${ }^{33}$ B. Polla $(1957,116 ; 1962,65)$ uvádza rozmery 1,07 x 0,90 x 0,40 m, ktoré však nezodpovedajú publikovaným nákresom a v pomere $\mathrm{k}$ iným uvádzaným rozmerom sa javia nesprávne.
} 

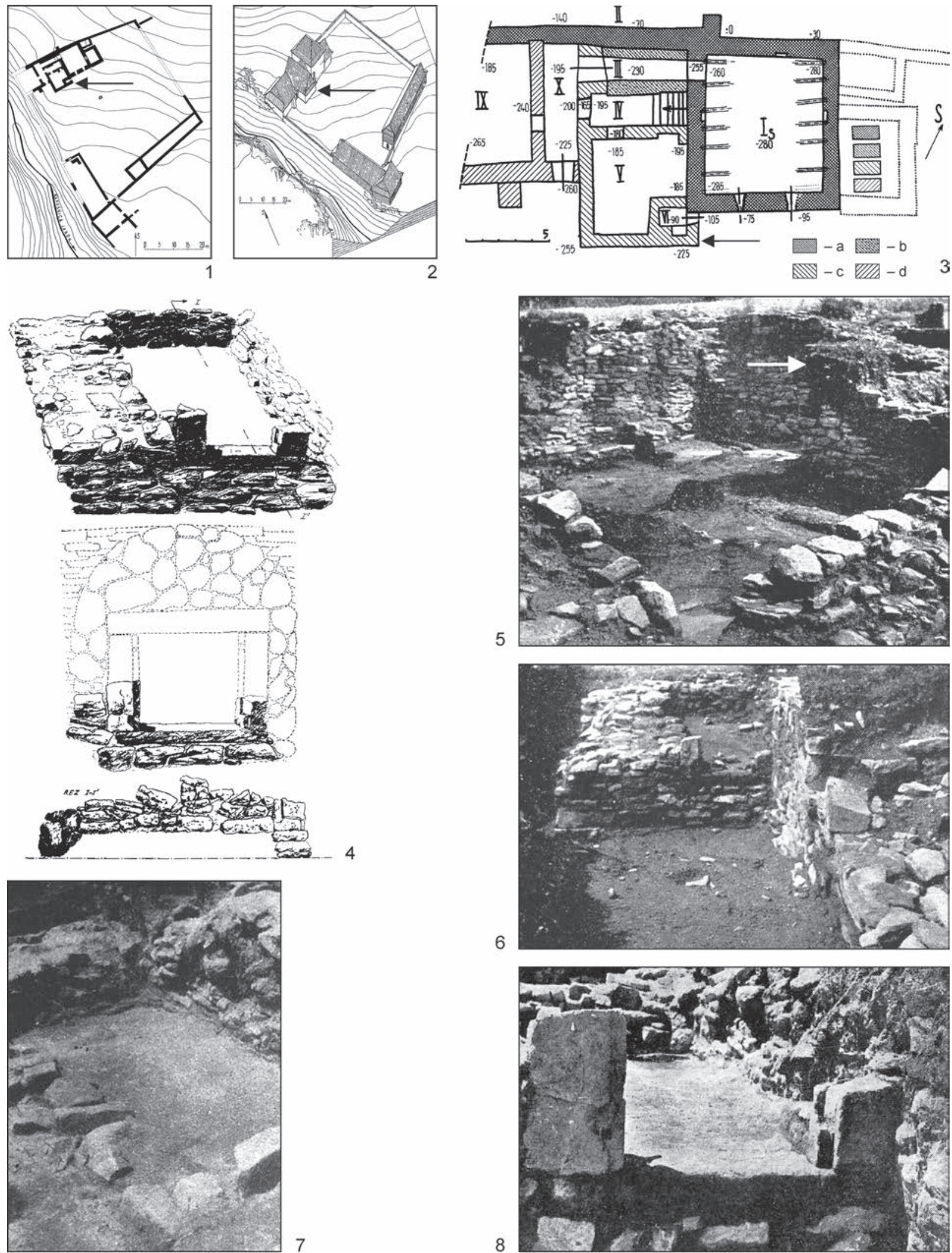

6

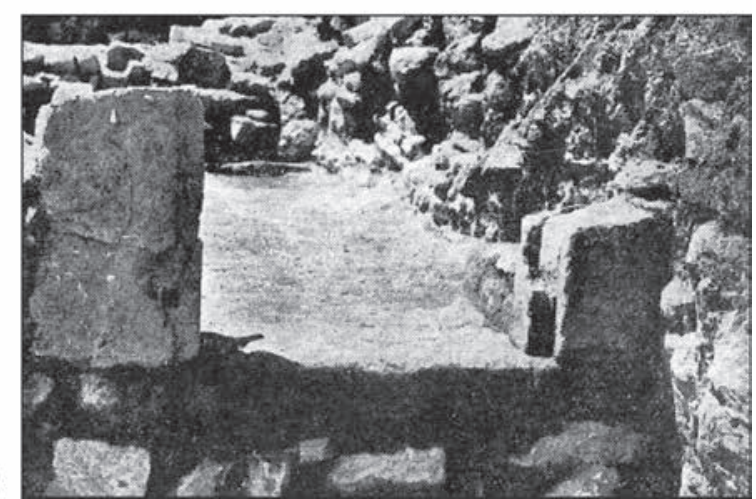

Obr. 12. Nemešany (Zalužany), panský dvorec. 1 - pôdorys dvorca s vyznačenou polohou pece; 2 - rekonštrukcia dvorca s vyznačenou polohou pece; 3 - pôdorys prízemia vykurovanej stavby s vyznačenou polohou pece; 4 - nákres torza pece; 5 - pohl'ad do miestnosti $V$ s pecou situovanou v nároží; 6 - pohl'ad na čelnú stenu pece; 7 - detail vnútra pece $(4,7$ podla Polla 1957); 8 - detail vstupu do pece (1-3, 5, 6, 8 podl’a Polla 1962). Legenda: a - 1. fáza; b - 2. fáza; c - 3. fáza; d - 4. fáza. 

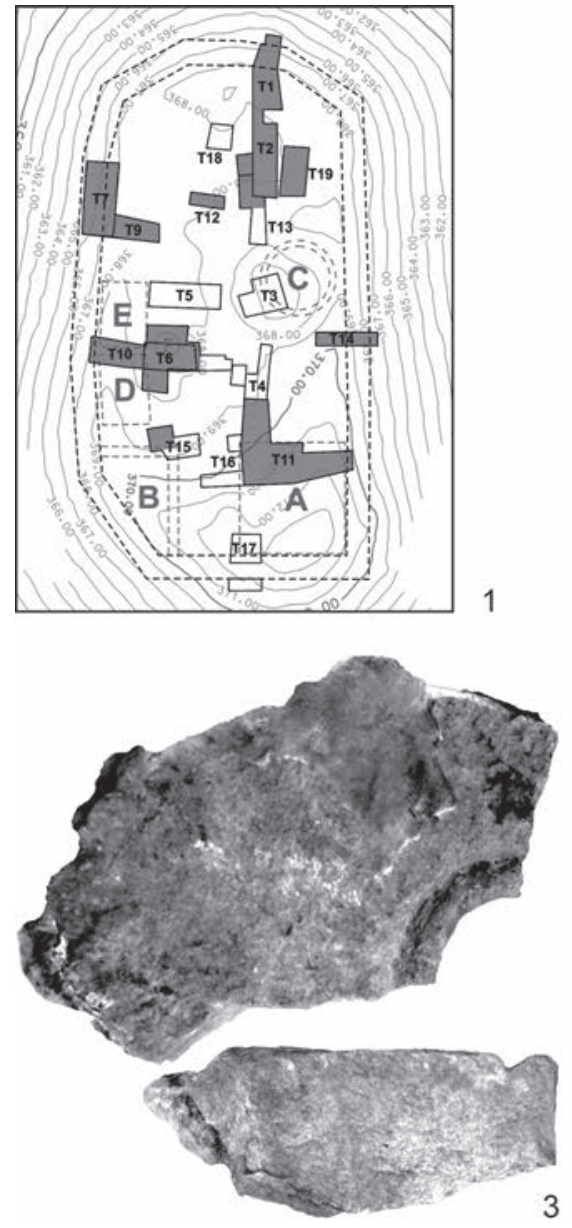

2

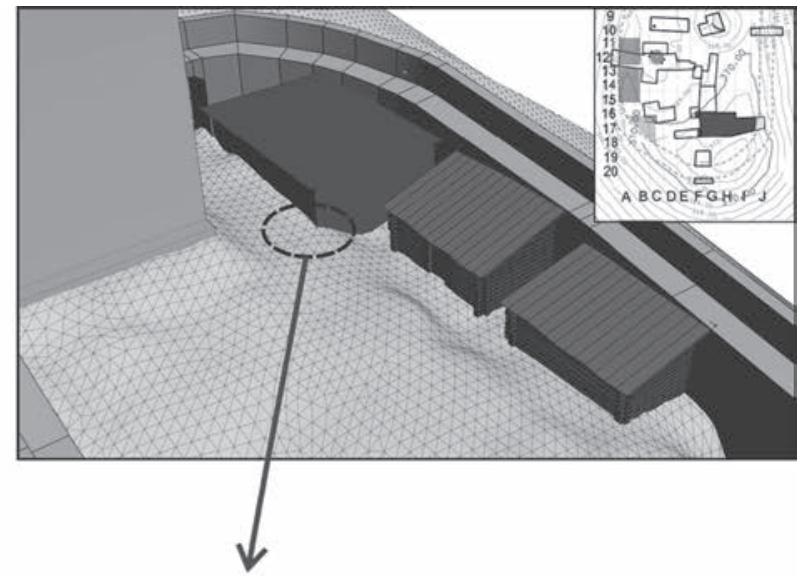

4

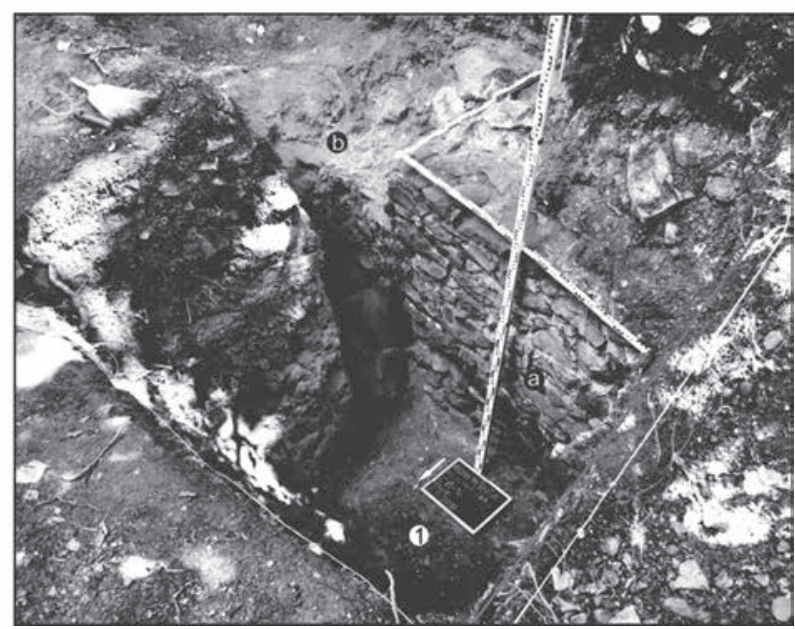

Obr. 13. Petuša, hrad. 1 - pôdorys hradu s vyznačenými sondami a identifikovanou architektúrou; 2 - rekonštrukcia prvej fázy zástavby hradu; 3 - fragment podlahovej platne so vzduchovodom (autor N. Beljak Pažinová); 4 - nárožie murovanej stavby v juhozápadnej časti nádvoria hradu (1, 2, 4 podl’a Styk/Beljak Pažinová 2020).

Nález v Nemešanoch je okrem toho zaujímavý tým, že dokladá používanie teplovzdušnej technológie $\mathrm{v}$ druhej polovici 14. stor. aj v prostredí nižšej šlachty. Dvorec vlastnili členovia zalužianského rodu a na konci 14. stor. bol jeho väčšinovým vlastníkom Martin, syn Hellebranda z Kežmarku, ktorého matka pochádzala z tohto rodu. Jeho potomkovia v roku 1412 odpredali väčšinu chotára Spišskej kapitule, ktorá sa v nasledujúcom období stala majitelom takmer celých Zalužian (Polla 1962, 154 n.).

\subsection{Pet’uša (katastrálne územie Ostrá Lúka), hrad}

Severozápadne od Pustého hradu pri Zvolene sa v lese nachádza malý, zaniknutý, ostrožný hrádok v polohe Petuša (371 m n. m.). Lokalita, ktorá leží v katastrálnom území obce Ostrá Lúka, je vo vizuálnom kontakte s Pustým hradom, vzdialená od neho približne $2 \mathrm{~km}$ vzdušnou čiarou. V teréne sa prejavuje len priebehom deštruovanej hradby, ktorej pôvodná výška sa odhaduje na 5 až $6 \mathrm{~m}$. Jadro hrádku má nepravidelný oválny tvar (44 x 24 m). Na základe získaných prameňov bol hrádok postavený na konci 13. stor. a zanikol najneskôr v prvej polovici 16. stor. Stavitela a majitela objektu nepoznáme. Predpokladá sa, že hrádok mohol byt’ súčastou ostrolúckeho panstva, resp. ho možno stotožnit’ s královskou mýtnou stanicou, čo sa javí pravdepodobnejšie. Medzi rokmi 2011 až 2017 sa tu realizoval archeologický výskum. Z hrádku pochádza prekvapivo bohatý súbor nálezov, dokladajúci aj dial'kový obchod (Beljak Pažinová 2017; Beljak Pažinová/Ragač 2018).

V roku 2014 objavili v západnej časti nádvoria hrádku (obr. 13: 1), v sekundárnej polohe, fragment podlahovej platne so vzduchovodom (obr. 13: 3; hrúbka $8 \mathrm{~cm}$, rozmery fragmentu 36 × 26 cm; Beljak Pažinová 2017, 461, obr. 9). Nález spol'ahlivo dokladá používanie teplovzdušnej technológie na lokalite a poukazuje na prekvapivo vyšší štandard bývania v menšom opevnenom sídle. Platňu zatial' nevieme spojit’ s konkrétnym vykurovacím telesom, či obytnou stavbou.

Doteraz sa črtá, že zástavbu hradu tvorila v juhovýchodnom nároží pravdepodobne drevená stavba (veže?), na murovanom štvorcovom základe $(9 \times 9 \mathrm{~m}$, obr. 13: 1 , 2). V juhozápadnej časti nádvoria bolo zachytené nárožie d’alšej murovanej stavby (obr. 13: 1, 2, 4; hrúbka 1,6 m, výška $1,7 \mathrm{~m}$, pravdepodobné rozmery 6,2 x 8,7 m). Na západnej strane nádvoria okrem toho boli dva drevené, zrejme zrubové objekty, ktoré mali suterén zahíbený do skalného podložia (obr. 13: 1, 2). V mladšej fáze tieto objekty zanikli a čiastočne nad nimi bolo postavené vel'ké kruhové ohnisko 

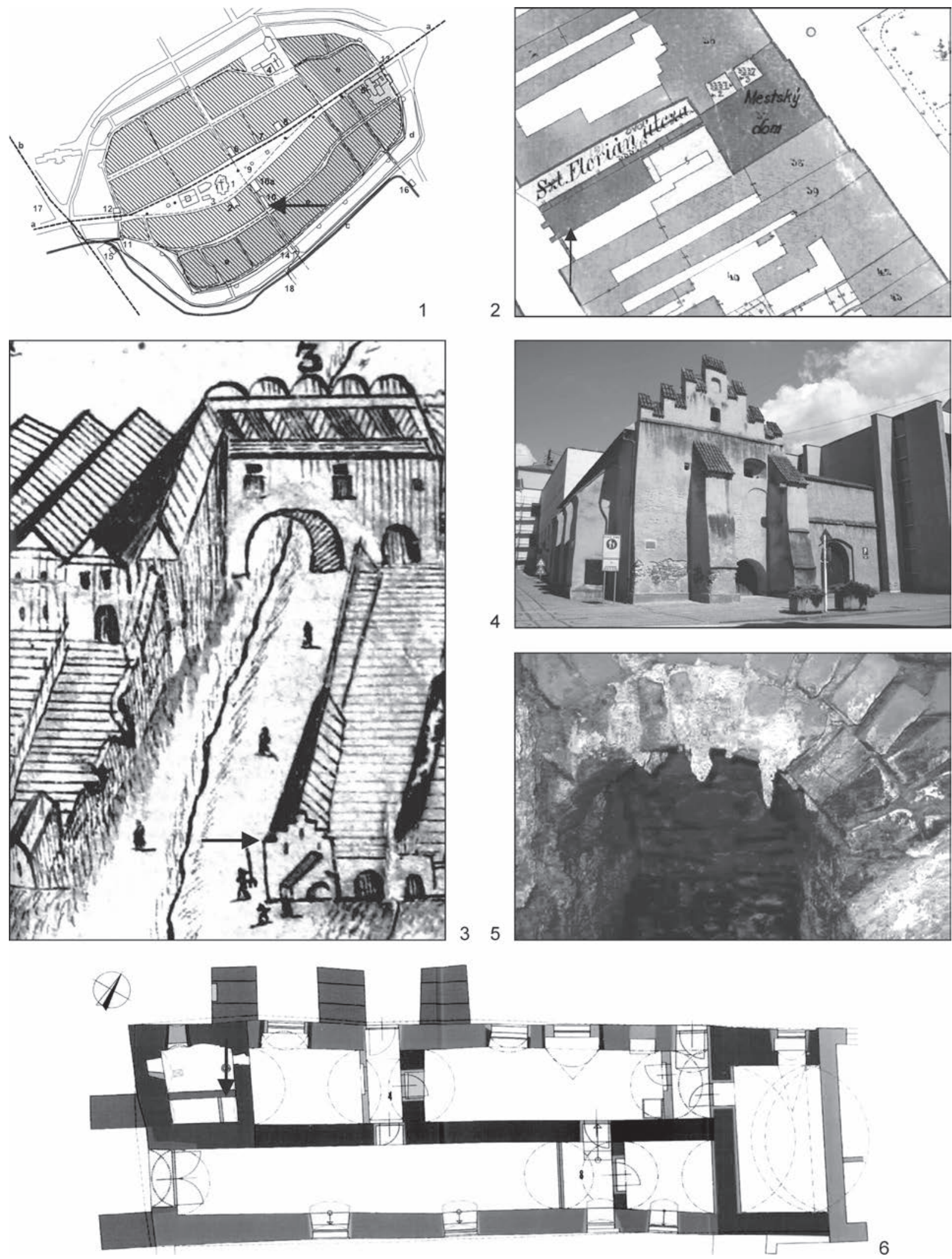

Obr. 14. Prešov, Caraffova väznica. 1 - plán mesta s vyznačenou polohou Caraffovej väznice (podla Urbanová 2003b); 2 - katastrálna mapa mesta z roku 1869 zachytávajúca objekt Caraffovej väznice; 3 - výsek z Casparovej veduty z roku 1768 zachytávajúci objekt Caraffovej väznice; 4 - pohl’ad na Caraffovu väznicu; 5 - pohlad na pec v západnej miestnosti; 6 - pôdorys prízemia s vyznačenou polohou pece $(2,3,5,6$ podla Petranská 2007). 
(pr. 1,4 m) prekryté prístreškom osadenom na 4 koloch (Styk/Beljak Pažinová 2020). Podlahová platňa sa našla na nádvorí hradu v blízkosti ohniska. Podobné dve okrúhle ohniska sa našli ešte v severnej časti hradu.

Publikovaný opis ohniska, resp. ohnísk nenaznačuje, že by mohlo íst’ o zvyšky teplovzdušnej pece. Tú najskôr bude možné hl'adat' $\mathrm{v}$ jednom $\mathrm{z}$ murovaných objektov hradu, pravdepodobne v juhozápadnej časti nádvoria, kde sa zatial' odkrylo len nárožie stavby. Z hrádku pochádzajú aj kamenné stavebné články potvrdzujúce prítomnost’ nadzemnej murovanej architektúry. Okrem toho treba upozornit na pozorovanie, že stavby na hrade boli po jeho zániku rozoberané. Datovanie vykurovacieho zariadenia zatial' môžeme hl'adat' len v celkovom chronologickom rámci osídlenia lokality. Podla nálezov sa jeho rozkvet črtá v 14. a 15. stor. Nález z Petuše je zaujímavý svojím výskytom $\mathrm{v}$ architektonickom kontexte menšieho hradu.

\subsection{Prešov, Caraffova väznica}

V písomných prameňoch mesta Prešov sa v 16. stor. stretávame s dvoma zmienkami spomínajúcimi hypocaustum. Prvá z roku 1540 uvádza, že príprava ciel v mestskom väzení zahŕňala aj „vymurovanie hypokausta“ (Pellová 2007, 28 , pozn. 13, 15). V prípade druhej ide o záznam v mestskej súdnej knihe z rokov 1555-1560. Píše sa v ňom, že istý Ján Roth bol na príhovor čestných mužov mesta namiesto v nevykúrenom pivničnom väzení zadržiavaný v miestnosti radnice nazývanej hypocausto (Szeghyová 1998, 74, pozn. 80).

Z uvedených zmienok vyvstáva viacero otázok. Prvou je, či možno použitý pojem považovat' za označenie teplovzdušného zariadenia. Zo situácie na Budínskom hrade vieme, že už od poslednej štvrtiny 15 . stor. sa termín mohol využívat’ aj na označenie vykurovanej miestnosti vo všeobecnosti, prípadne mohol byt’ použitý na označenie kachlovej pece (Zolnay 1976, 217). K opatrnosti v tomto smere nás nabáda aj informácia, že pri prvej správe ide o zariadenie postavené v roku 1540. V tomto období bola teplovzdušná technológia dávno za zenitom a kachlové pece sa na území Slovenska presadzujú už aj v dedinskom prostredí (Hoššo 1999, 406). Spol'ahlivú odpoved' na riešenú otázku nám umožní až archeologický výskum. Písomné zmienky však okrajové používanie hypokaust v 16. stor. pripúštajú, resp. nevylučujú.

Ďalšou otázkou je, či správy hovoria o dvoch, alebo o jednom zariadení, resp. miestnosti. So samotných zmienok to nemožno posúdit. Faktom však je, že v obidvoch prípadoch sa pojem uvádza v súvislosti s väzením, čo by mohlo naznačovat', že išlo o jeden objekt. Túto možnost’ podporuje aj predpokladané situovanie radnice a mestského väzenia na jednej parcele. Ich lokalizácia v meste je ale predmetom polemiky.

Polohu pôvodnej stredovekej radnice, spomínanej od roku 1429, nepoznáme. Niektorí bádatelia ju neopodstatnene lokalizovali do meštianskeho domu na východnej strane námestia (Hlavná ul. č. 82). Inú pravdepodobnejšiu alternatívu predstavuje situovanie radnice vychádzajúce z vyobrazenia Casparovej veduty z roku 1768, do centra hlavného námestia, južne od kostola sv. Mikuláša. Tento priestor zatial' nebol archeologicky skúmaný a v súčasnosti sa tu nachádza Neptúnova fontána. Vyobrazený objekt zanikol niekedy po roku 1788, kedy mesto zasiahol vel'ký požiar, ktorý spálil celé horné námestie. Medzi poškodenými objektmi sa vtedy spomína aj radnica (Domenová 2010, 335 n.; Pellová 2007, 32).

Z náznakov v písomných prameňoch však vieme, že už v 17. stor. funkciu radnice plnila pravdepodobne iná budova. Ide o objekt situovaný na západnej strane námestia (Hlavná ul. č. 73), ktorý vznikol prestavbou v rokoch 1504-1509 zo staršieho meštianskeho domu (obr. 14: 1, 2; Pellová 2007, 32, pozn. 45). Mesto ho odkúpilo pre svoje potreby a nachádzala sa tu mestská vináreň. Niektorí bádatelia vináreň lokalizujú len do suterénu stavby a funkciu radnice pripisujú objektu už od jeho prestavby na začiatku 16. stor. (Domenová 2010, 335 n.). V tomto objekte radnica sídli dodnes.

$S$ riešenou stavbou úzko súvisí aj identifikácia väznice vybavenej v roku 1540 hypokaustom. Mesto v novoveku disponovalo viacerými väznicami, napr. v roku 1603 sa spomínajú tri v baštách mestského opevnenia (Suchý 1974, 77 n.). V rokoch 1530, 1558, 1618 a 1687 sa však stretáme aj s väznicou situovanou pri mestskej vinárni (Pellová 2007, 28 n., pozn. 12; Szeghyová 1998, 72, pozn. 71; Urbanová 1986, 22 n.; 2003b, 613 n.). Na rovnakej parcele ako vináreň, resp. radnica sa nachádza objekt známy ako Caraffova väznica (obr. 14: 2-4). ${ }^{34}$ Ide o stavbu na rozhraní ulíc Floriánovej a Jarkovej, ktorá plnila v minulosti viacero úloh. Slúžila ako sklad vinárne, zbrojnica, depozit mestských mier a váh, a vo viacerých časových úsekoch aj ako väzenie (Domenová 2010, 336). Vzhl'adom na zmienku o miestnosti radnice vykurovanej hypokaustom, ktorá slúžila ako väzenie usudzujeme, že hladaný objekt by bolo možné lokalizovat' do tejto stavby.

Podla stavebno-historického výskumu sa Caraffova väznica v základnej dispozícii sformovala na začiatku 16. stor., po požiari v roku $1503 .{ }^{35}$ Vznikla spojením dvoch starších gotických budov na jeho západnom a východnom okraji (obr. 14: 6). ${ }^{36} \mathrm{~V}$ druhej polovici 16. stor. bola dispozícia spojeného komplexu stavieb rozdelená na dva trakty. Neskôr v novoveku prešiel objekt d'alšími stavebnými úpravami (Petranská 2007, 57-69).

Autorka stavebno-historického výskumu D. Petranská (2007, 10 n., 47 n., 57, 67 n.) uvažuje o lokalizácii v prameňoch spomínanej vykurovacej pece do západnej, resp. severozápadnej miestnosti Caraffovej väznice (obr. 14: 6). Tá nemala od počiatku žiadny vstup z prízemia, čo je pozoruhodné a prístupná bola aj neskôr len z hora z poschodia. Pod touto miestnostou sa nachádza aj bližšie nepreskúmaný suterén, zaberajúci len južnú polovicu priestoru. V miestnosti je na prízemí zhodou okolností situované aj akési šachtovité vykurovacie teleso, tvoria ho však minimálne z časti aj mladšie novoveké konštrukcie (obr. 14: 5; 19. až prvá polovica 20. stor.). V objekte je potrebné realizovat d’alší výskum, ktorý by overil tu predpokladané vykurovacie zariadenie.

Zmienky o hypokauste v Prešove sú zaujímavé z viacerých aspektov. Jednak naznačujú potenciálne prežívanie teplovzdušnej technológie $\mathrm{v}$ mestskom prostredí ešte v 16. stor. a pozoruhodné je aj ich ojedinele evidované

\footnotetext{
${ }^{34}$ Pomenovanie objektu súvisí s udalostami tzv. Prešovských jatiek v roku 1687. Vtedy bolo pod vedením generála A. Caraffu popravených 24 uhorských zemanov a meštanov údajne zapojených do Tökölyho povstania. Kvôli vel'kému počtu väzňov bolo využívaných viacero väzníc v meste, medzi nimi pravdepodobne aj budova dnes známa ako Caraffova väznica (Pellová 2007, 31 n.).

${ }^{35}$ Ďakujem D. Petranskej za poskytnutie výskumnej dokumentácie.

${ }^{36}$ Objekt na východnom konci zrejme predstavoval gotický dom vežového typu s polozapusteným suterénom. Západný objekt nevieme bližšie charakterizovat', jeho identifikovanú čast však tvorí približne štvorcová stavba.
} 

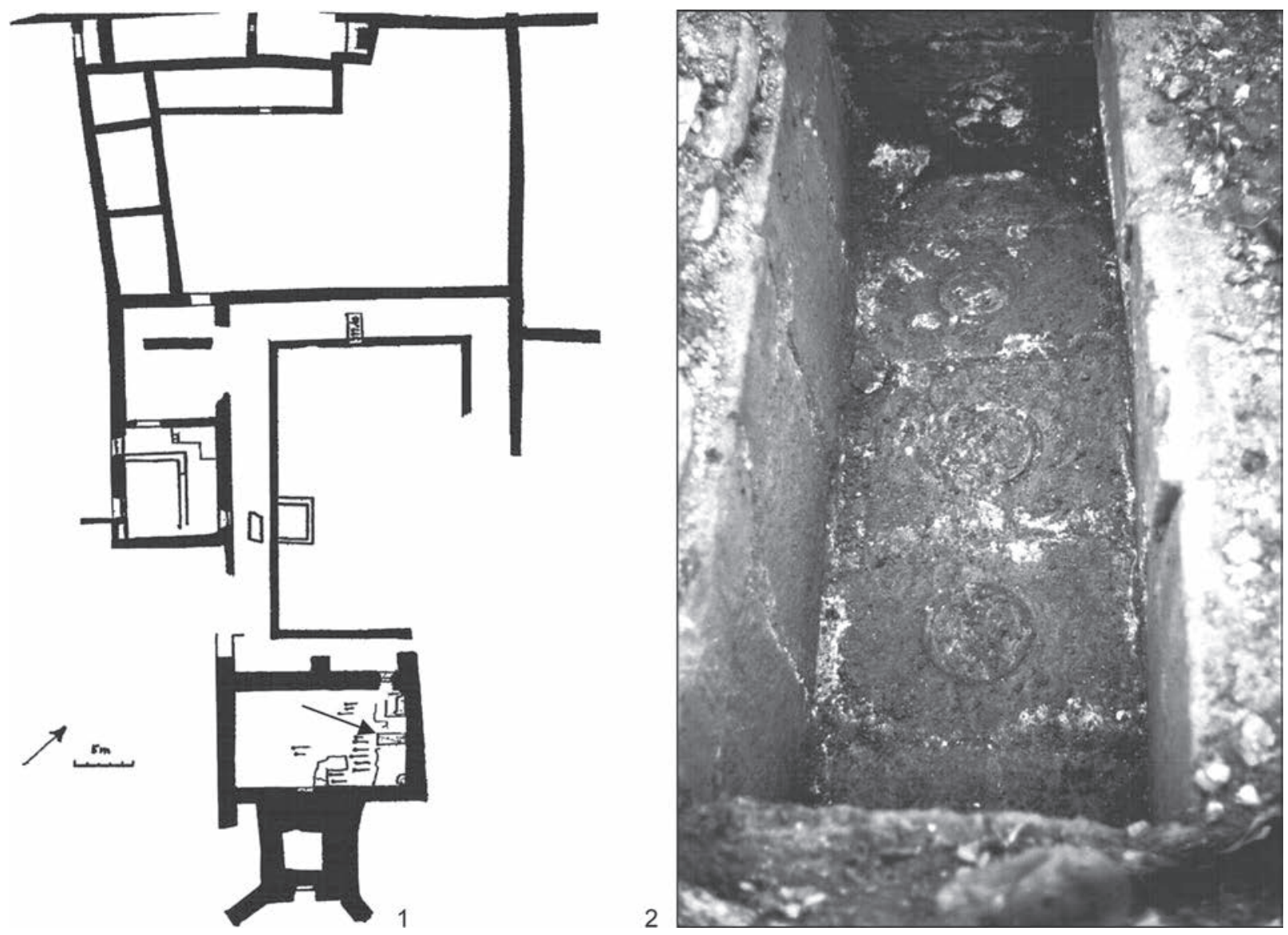

Obr. 15. Slovenská L’upča, kláštor františkánov. 1 - pôdorys kláštora s vyznačenou polohou hrobky (podl'a Mosný/Selecká 2006); 2 - pohlad na konštrukciu hrobky z podlahových platní hypokausta (autor P. Mosný).

využitie v mestskej väznici. Písomné správy poukazujú aj na spoločenskú prax, pri ktorej mesto na uväznenie popredných meštanov použivalo pohodlnejšie, vykurované, väzenie (Szeghyová 1998, 74).

\subsection{Slovenská L’upča, kláštor františkánov}

Existenciu františkánskeho kláštora v Slovenskej L’upči prvý raz dokladá správa z roku 1263 . V prvej polovici 14. stor. a na prelome 14. a 15. stor. prešiel kláštor viacerými prestavbami a medzi rokmi 1528-1531 dochádza $\mathrm{k}$ jeho zániku. Na lokalite sa od 70. rokov realizovalo viacero výskumov, ktoré postupne odkryli väčšiu čast' kláštorného areálu (Hanuliak/Ragač 2000; Mosný/Selecká 2005; 2006; Pomfyová 2018, 67, 68, 108-110; Rábik 2010).

Počas výskumu v interiéri lode hlavného kostola bola v jeho východnej časti, v osi kostola, odkrytá murovaná hrobka datovaná do prvej polovice 18. stor. (obr. 15). Vyhotovená bola zo sekundárne použitých, opracovaných, kamenných platní, spájaných maltou (22ks). Śtyri z platní mali
V strede kruhové otvory, lemované hlbokým žliabkom. ${ }^{37}$ Otvory boli zaliate maltou (Mosný/Selecká 2006, 345 nn.)

Vzhl'adom na charakteristickú formu otvorov usudzujeme, že ide o platne, ktoré pôvodne prekrývali teplovzdušnú pec a tvorili podlahu jednej z kláštorných miestností. Zverejnené výsledky výskumu sa o náleze hypokausta v kláštore nezmieňujú a dostupné informácie zatial' neumožňujú bližšie uvažovat’ o jeho lokalizácii.

\subsection{Spišské Podhradie-Pažica}

V 70. rokoch bol pod vedením A. Vallaška (1999) oproti Spišskej Kapitule v polohe Pažica odkrytý pomerne rozsiahly, ohradený komplex stavieb (obr. 16: 1).$^{38}$ Areál nepravidelného lichobežníkového tvaru (94/57 x 86/76 m) datoval autor výskumu do 11. až 15. stor. Výskum tu identifikoval viacero obytných stavieb, zahĺbené priestory (pivnice), výrobné objekty (pece), studňu, ako aj architektúru s potenciálne sakrálnou funkciou. ${ }^{39}$ Väčšina architektúr bola vymurovaná na hlinu a pravdepodobne predstavovala podmurovky

\footnotetext{
${ }^{37}$ Za sprístupnenie fotodokumentácie hrobky d’akujem P. Mosnému.

38 Ďakujem R. Vallaškovej za sprístupnenie nálezových správ a dokumentácie z výskumu a Martinovi Stejskalovi za poskytnutie fotodokumentácie nálezu.

${ }^{39}$ Okrem naznačenej apsidy by na túto funkciu mohol poukazovat’ aj nález travertínového kríža a fragment kruhovej sväteničky, ktoré na základe zápisnice zo záverečnej komisie z výskumu uvádza M. Slivka (2001-2002, 27). A. Vallašek (1976, 30)
} 

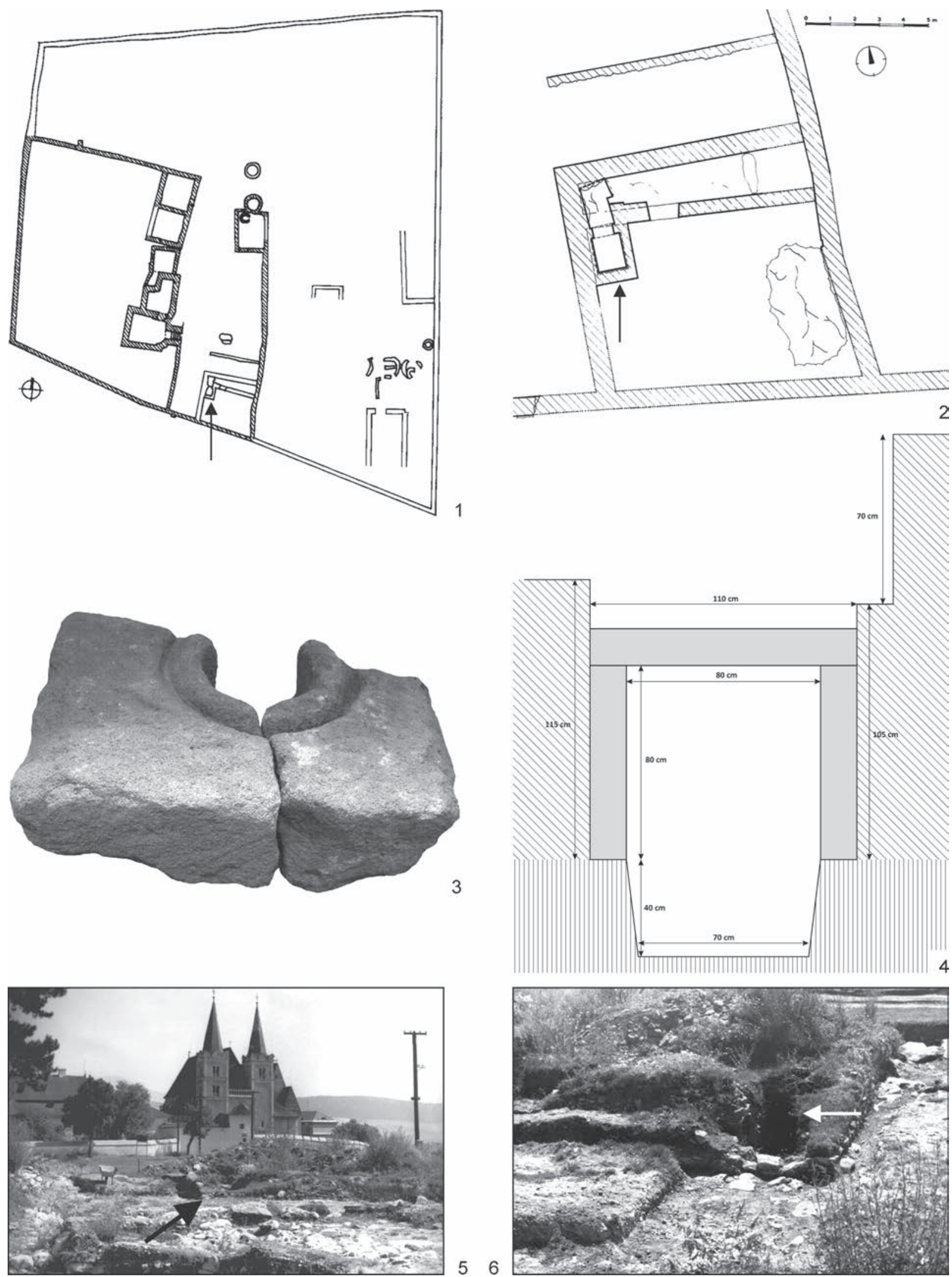

56

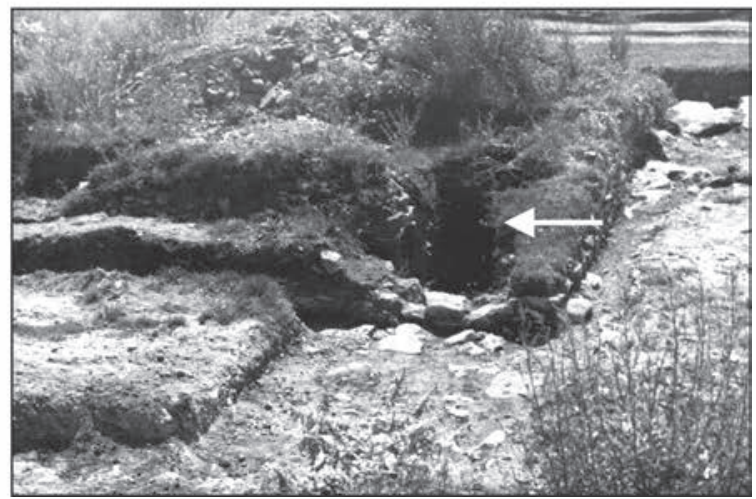

Obr. 16. Spišské Podhradie-Pažica. 1 - plán lokality s vyznačenou polohou pece (podla Vallašek 1999); 2 - pôdorys vykurovaného objektu a pece (autor D. Tóth); 3 - fragment podlahovej platne so vzduchovodom (podla Stejskal 2009); 4 - pohl’ad na vstup do pece (podl’a terénneho náčrtu A. Vallaška); 5, 6- pohl’ad na vykurovaný objekt s vyznačenou polohu pece (autor A. Vallašek). 
pre zrubové stavby. Vyskytla sa tu však aj kvalitnejšia architektúra spájaná maltou, ktorú A. Vallašek identifikoval ako mladšiu stavebnú etapu datovanú do 14. stor.

Názory na funkciu odkrytého komplexu prešli postupným vývojom. Autor výskumu interpretoval lokalitu ako benediktínsky kláštor, vychádzajúc z listiny z roku 1274 spomínajúcej „monasterium beati Martini“. Na základe písomných prameňov lokalizoval do objektu aj špitál, ktorý mal v roku 1391 získat’ rád augustiniánov (Vallašek 1999). Iný pohl’ad na lokalitu ponúkol M. Slivka (2001-2002; 2003), ktorý areál interpretoval ako predchodcu kapituly a pripísal ho regulovaným kanonikom. Najnovšie sa k lokalite vyjadril v diskusnom príspevku L. Koszta (2009), ktorý interpretáciu objektu ako kláštora vo všeobecnosti odmieta. Argumentuje najmä viacznačnostou pojmu monasterium v stredovekej latinčine ${ }^{40}$ a nepravdepodobnostou existencie kláštora na Spiši v 11., či 12. stor. Komplex stavieb identifikoval ako areál, ktorý plnil najmä hospodárske úlohy a prestavby zo 14. stor. dal do súvislosti s potrebou zväčšit kapacitu areálu, pretože sedria Spišskej stolice v druhej polovici 14. stor. zasadala pri kapitule, na Vrchu sv. Martina.

Teplovzdušné vykurovacie zariadenie sa nachádzalo v samostatnej stavbe pri južnom okraji areálu, približne v strede jeho dížky (obr. 16: 1). Budova vznikla pravdepodobne až $\mathrm{v}$ rámci mladšej stavebnej etapy prístavbou obvodových múrov k staršiemu ohradnému múru, ako aj k d’alšiemu severo-južne orientovanému murivu, rozdelujúcemu areál čiastočne na západnú a východnú častet. ${ }^{41}$ Autor výskumu stavbu interpretoval ako dom priora. Novšie názory na funkciu celého areálu však umožňujú pripísat objektu len všeobecne obytnú funkciu. Stavba s rekonštruovanými rozmermi cca 9 × 10 m pozostávala $z$ väčšej miestnosti a chodby širokej 1,1-1,9 m, situovanej na severnej strane objektu (obr. 16: 2). Vymurovaná bola z lomového kameňa kladeného na maltu. Vo východnej časti objektu sa nachádzala pivnica, vysekaná do skalného podložia.

Teplovzdušná pec bola umiestnená v severozápadnom nároží stavby (obr. 16: 2, 6), čiastočne v interiéri miestnosti a sčasti v chodbe. Vykurovacia komora zachádzala do interiéru a bola zapustená do podložia, do híbky 1,45-1,55 m a následne obmurovaná kameňmi a tehlou. Jej vnútorné rozmery boli 1,1 x 1,4 m. Bočné steny vytvárali v spodnej časti schod, vysoký $0,4 \mathrm{~m}$ a široký $0,15-0,20 \mathrm{~m}$, na ktorom bol osadený už nedochovaný rošt pece. Vo vrchnej časti stien pece sa nachádzal zásek na uloženie kamenných platní prekrývajúcich pec. Komora bola prístupná cez otvor, lemovaný ostením z pieskovcových kvádrov s rozmerom 80 x $80 \mathrm{~cm}$ (obr. 16: 4). Na dne pece zachytili vrstvu popola. Pochádza z nej viacero prepálených okruhliakov, ako aj fragmenty miskovitých nádob so stopami po ohni, ktoré podla autora výskumu mohli slúžit na prekrytie otvorov v podlahových platniach. Viaceré fragmenty platní so vzduchovodmi (45 x ? (31) x $15 \mathrm{~cm}$, otvor s pr. $12,5 \mathrm{~cm})$ sa našli mimo hypokausta, v zásype pivnice (obr. 16: 2, 3; Stejskal 2009, 132 n.). Obslužný priestor zariadenia bol situovaný v chodbe. Rovnako ako pec bol zahĺbený do skalného podložia a následne obmurovaný. Mal obdlžnikový tvar s rozmermi $0,8 \times 2 \mathrm{~m}$, pričom na severnom konci ho rozšírili o 0,3 x 0,4 m do tvaru písmena L (obr. 16: 2).

Pec identifikujeme ako hypokaustum IV. typu. Autor výskumu datoval výstavbu pece do 14 . stor. a považuje ju za jednu z posledných stavebných aktivít $\mathrm{v}$ rámci lokality. Zánik a opustenie areálu kladie do prvej polovice 15. stor. (Vallašek 1999, 65).

\subsection{Spišský hrad (katastrálne územie Žehra)}

Potenciálne teplovzdušné vykurovacie zariadenie bolo odkryté počas archeologického výskumu Spišského hradu v roku 1973. Objekt sa nachádza na hornom hrade, v rámci zástavby pozdĺž východnej strany opevnenia (obr. 17: 1, 2; Vallašek 1973, 17-19).

Zariadenie pozostávalo z vykurovacej a obslužnej predpecnej časti (obr. 17: 2, 3). Obslužná čast’ mala obdížnikový pôdorys s rozmermi 1,4 × $2 \mathrm{~m}$ a híbku 2,04 m. Steny boli obmurované z lomových kameňov kladených na ílovitú hlinu a mali šírku 0,6-0,7 m. Najlepšie sa dochovala východná stena, ktorá svojou korunou siahala po úroveň základového odskoku gotickej stavby a definuje približnú pochôdznu úroveň v čase používania zariadenia. Podlaha obslužného priestoru bola vyhotovená z vel'kých plochých kameňov.

Vykurovacia komora bola $\mathrm{z}$ väčšej časti situovaná v exteriéri, severne od gotickej stavby a sčasti zabiehala do jej interiéru (obr. 17: 2, 3). Gotická stavba je však mladšia a jej základy pec porušili. Čast' komory dochovaná v exteriéri mala rozmery $0,80 \times 1,75 \mathrm{~m}$. Steny boli vymurované $\mathrm{z}$ tehál (30 x 13 × 7,5 cm) spájaných ílom. Čelná stena mala hrúbku 0,45 m. Nachádzal sa v nej vstupný otvor, vel'ký 70 x $60 \mathrm{~cm}$, prekrytý väčším pieskovcovým kvádrom, ktorý bol z vnútornej strany prepálený (obr. 17: 5, 6). Dno pece ležalo v rovnakej úrovni ako vstupný otvor a tvorila ho $8 \mathrm{~cm}$ hrubá vrstva dočervena prepáleného ílu.

Autor výskumu datuje výstavbu pece do 14 . stor. až prvej polovice 15 . stor. K jej zániku došlo pri výstavbe gotického objektu, ktorý pec narušil. Ten je datovaný do 15. stor., resp. do jeho druhej polovice (Janovská 2012, 295; Plaček/ Bóna 2007, 272-275; Vallašek 1973, 19). Vzhladom na zahíbenie pece pod dobovú pochôdznu úroveň, morfologickú podobnost' a situovanie na hornom hrade sa domnievame, že by mohlo íst’ o teplovzdušné vykurovacie zariadenie. Problematickým je však jeho architektonický kontext.

Podl'a dosial' realizovaných výskumov nebol v rámci východnej zástavby horného hradu pri peci spolahlivo identifikovaný obytný objekt, ktorý by chronologicky a priestorovo zodpovedal zariadeniu. V tesnej blízkosti pece sa nachádza

v nepublikovanej nálezovej správe rovnako uvádza z objektu nález kríža s rozšírenými horizontálnymi ramenami, sväteničku, ako aj striebornú sponu, údajne z pluviála (liturgický odev) a fragment kachlice s motívom kríža. Avšak d’alej v texte sa rozporuplne neodvoláva na nález kríža, ale na fragment travertínového portálu, ktorého d’alšie fragmenty sa našli v objekte s vykurovacím zariadením (Vallašek 1976, 35). Pri predpokladanej sakrálnej stavbe, ako aj v celom areáli však chýbajú nálezy hrobov. Doložené sú až v priestore kapituly (Vallašek 1999, 65).

${ }^{40}$ Pojem mohol byt’ použitý aj vo význame kapitula, alebo kostol s dvoma vežami, postavený „ad modum monasterii“, t. j. ako Katedrála sv. Martina v Spišskej Kapitule.

${ }^{41}$ A. Vallašek uvádza existenciu staršej stavebnej fázy objektu, vymurovanú na hlinu, ktorej obvodové múry boli údajne prestavané s maltovým spojivom až pri konštrukcii hypokausta (Vallašek 1976, 34-37; 1999, 65). Na základe dostupnej dokumentácie sa tvrdenie javí ako málo pravdepodobné. M. Slivka (2001-2002, 27 n.) interpretuje celú stavbu ako mladší pristavaný objekt. 

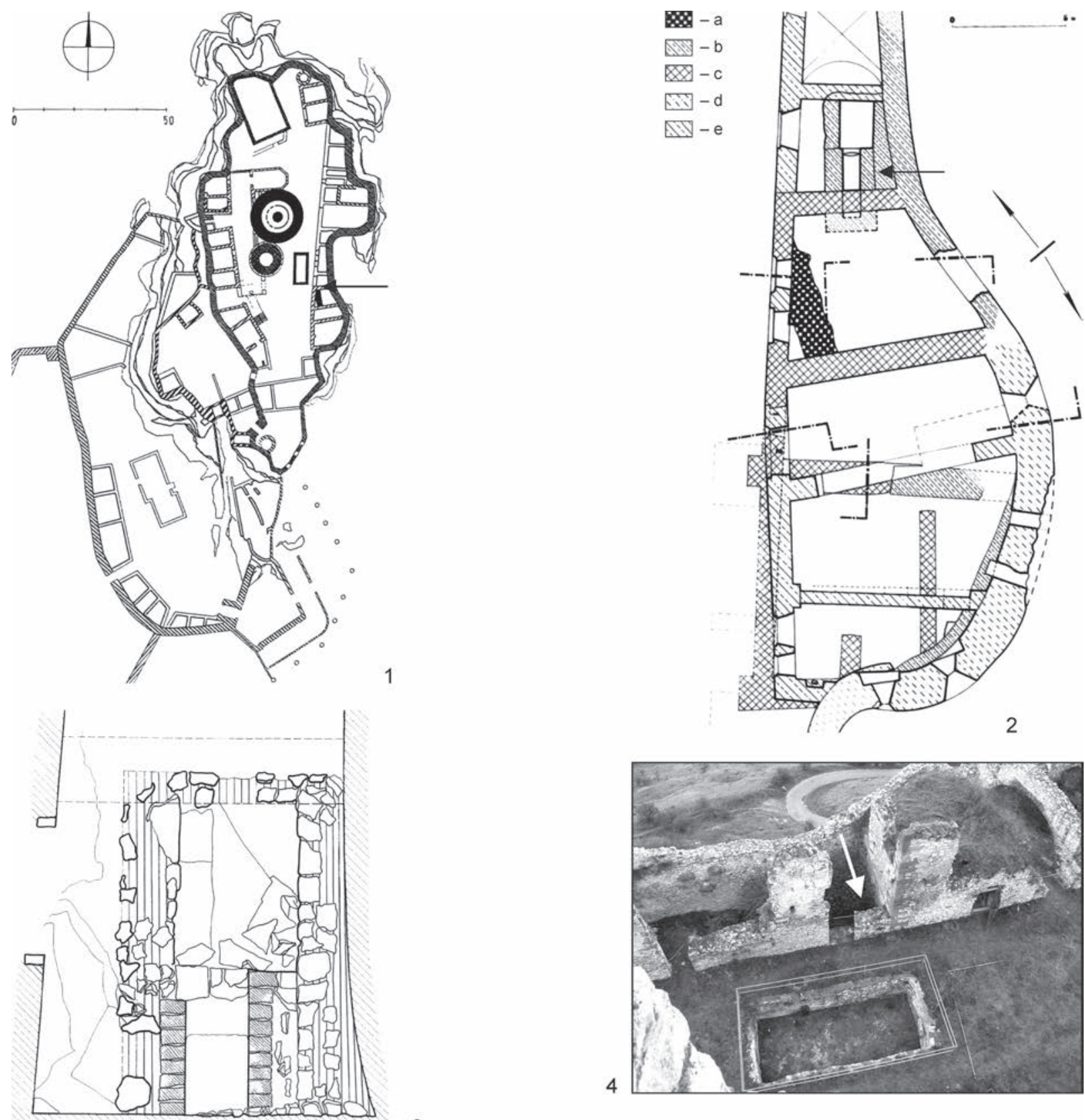

3
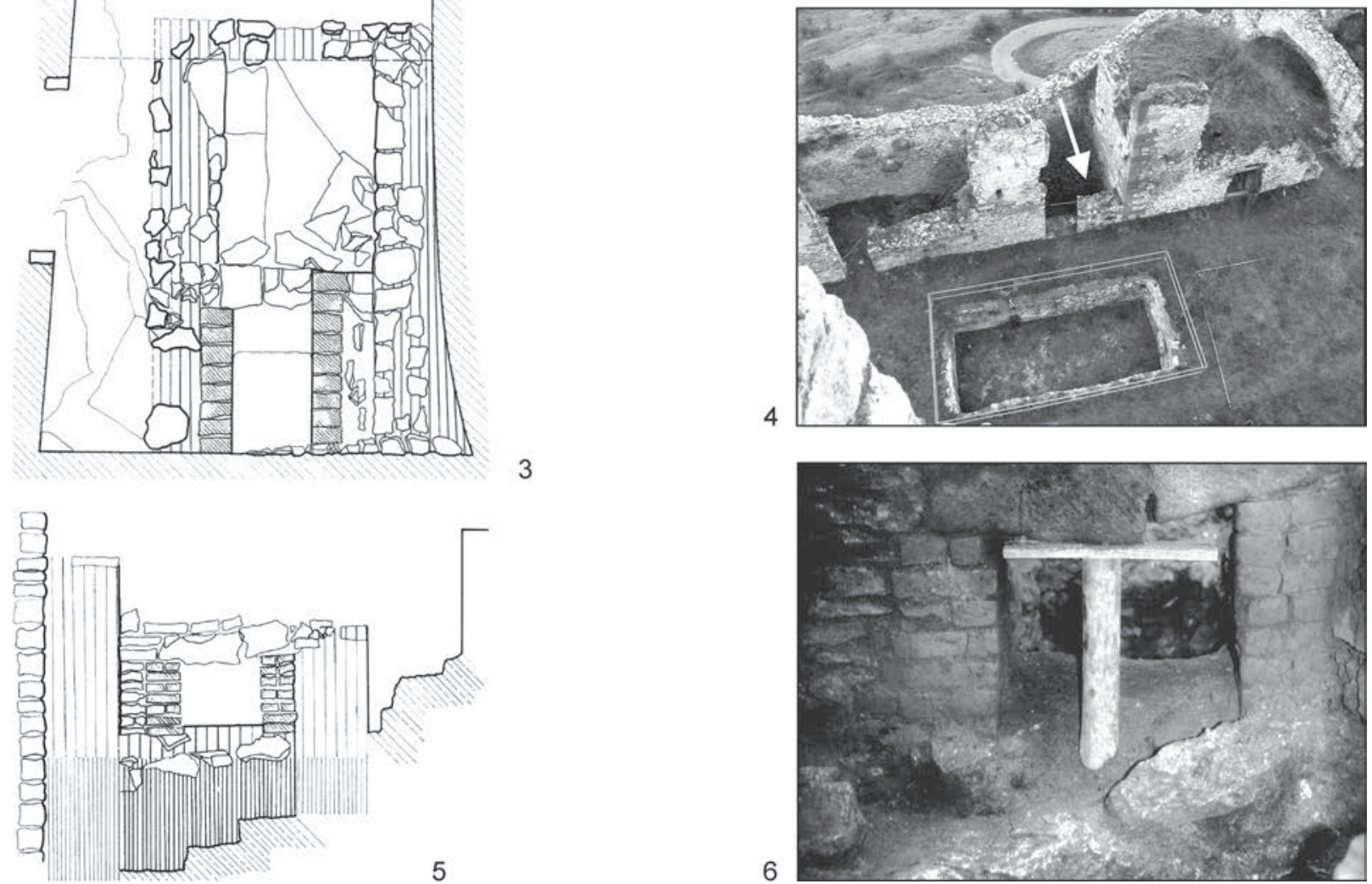

Obr. 17. Spišský hrad. 1 - plán hradu s vyznačenou polohou pece (podla Plaček/Bóna 2007); 2 - pôdorys juhovýchodnej časti hradného jadra s vyznačenou polohou pece (autori A. Vallašek a A. Fiala); 3 - pôdorys severnej časti pece; 4 - pohlad na juhovýchodnú čast' horného hradu s vyznačenou polohou pece; 5, 6-pohlad na vstup do pece (3, 5, 6 autor A. Vallašek). Legenda: a - pred 13. stor.; $\mathrm{b}-14$. stor.; $\mathrm{c}-15$. stor.; $\mathrm{d}-16$. stor.; $\mathrm{e}-17$. stor. 

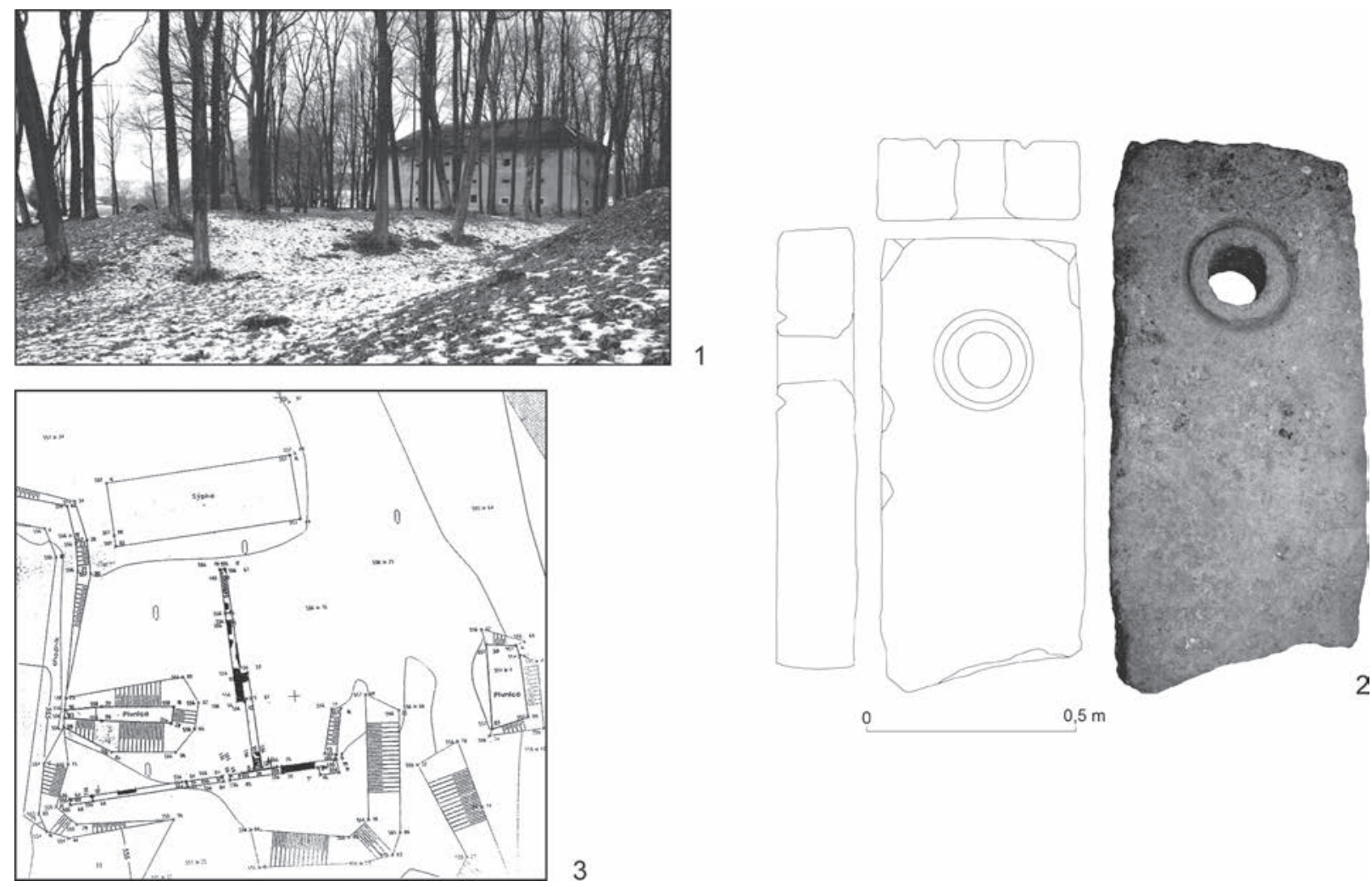

Obr. 18. Spišský Štiavnik, kláštor cisterciánov. 1 - pohlad na polohu zaniknutého kláštora; 2 - podlahová platňa so vzduchovodom; 3 - zameranie sond a zachytených architektúr kláštora (podla Kopták 2012).

len torzo staršieho muriva, datované pred 13. stor., avšak jeho funkcia a širší pôdorys nie sú bližšie známe (obr. 17: 2). Další potenciálny obytný objekt sa črtá až cca 10 m južne od pece. V priestoroch mladšej gotickej stavby tu boli zachytené aj torzá starších murív zo 14. stor. Vzhladom na uvedené problémy zatial' nemožno vylúčit, že ide aj o väčšiu potravinovú pec. $\mathrm{V}$ prospech toho by mohla hovorit napr. blízko situovaná cisterna, hoci hospodársko-prevádzkové objekty a funkcie hradu sa od poslednej tretiny 14. stor. lokalizujú do druhého predhradia (Plaček/Bóna 2007, 273).

\subsection{Spišský Štiavnik, kláštor cisterciánov}

Cisterciánske opátstvo v Štiavniku, pravdepodobne jedno z najbohatších v strednej Európe, bolo založené v roku 1223. V roku 1237 sa však ešte uvažovalo o jeho presídlení. Pôvodný kláštor, zrejme drevené provizórium, vyhorel krátko pred, či v roku 1260 a musel byṫ obnovený, pričom sa predpokladá, že v 14. stor. už bol dobudovaný. Opátstvo definitívne zaniklo po predchádzajúcom lúpežnom prepade v roku 1543. Jeho stavebný materiál sa použil na výstavbu blízko situovaného kaštiela, dokončeného v roku 1619 (Jakubčin 2018; Kopták 2012; 2014; Pomfyová 2003, 618 n.; 2015, 760-762).

Kláštor sa nad úrovňou zeme nedochoval, na lokalite stojaca baroková sýpka však stojí na základoch kostola (obr. 18: 1,
3). Južne od nej sa nachádza plocha kláštora (Slivka 1993, 191). V rokoch 2006 až 2007 sa tu realizoval archeologický výskum, ktorý identifikoval viacero stredovekých murív (obr. 18: 3) a naznačil, že v prvej fáze mohlo íst' o drevenú stavbu (Kopták 2014). V roku 2018 sa tu uskutočnil, zatial' nepublikovaný, geofyzikálny výskum dobre zachytávajúci pôdorys kláštora. ${ }^{42}$ Z lokality pochádza viacero architektonických článkov dokladajúcich výstavbu kláštorného kostola pravdepodobne po roku 1260, ktorá sa zrejme tiahla až do 80 . rokov 13. stor. (Pomfyová 2000-2001, 306; 2003, 618 n.; 2015, 760-762).

Spol’ahlivým dokladom, že kláštor disponoval teplovzdušným vykurovacím zariadením je nález masívnej, kamennej, podlahovej platne s kruhovým otvorom (obr. 18: 2). ${ }^{43}$ Platňa sa našla v sekundárnej polohe, v jednej z dvoch dodnes dochovaných pivníc kláštora, situovanej juhovýchodne od sýpky (obr. 18: 3). Jej rozmery sú: hrúbka $17 \mathrm{~cm}$, šírka $44 \mathrm{~cm}$ a zachovaná dížka $97 \mathrm{~cm}$. Platňa má excentricky na jednej strane kruhový otvor lemovaný žliabkom, jeho priemer je cca $12 \mathrm{~cm}$ a priemer žliabku $19 \mathrm{~cm}$. Ide o najväčší exemplár podlahovej platne na sledovanom území.

Lokalizáciu hypokausta môžeme len hypoteticky predpokladat, podobne ako v ostatných kláštoroch, v krídle oproti kostolu, $\mathrm{v}$ našom prípade $\mathrm{v}$ južnom. Zariadenie tu mohlo vykurovat’ refektár, resp. calefactorium, charakteristické najmä pre cisterciánske kláštory. V prípade, že sa podobný priestor nachádzal aj v štiavnickom kláštore, možno ho očakávat západne, ned’aleko pivnice, kde sa platňa

\footnotetext{
${ }^{42}$ Výskum realizovali M. Felcan, Z. Felcanová, D. Kušnirák a R. Pašteka. Ďakujem jeho autorom za možnost nahliadnut na výsledky. ${ }^{43}$ Ďakujem M. Hudákovi za sprístupnenie nálezu.
} 
našla, čomu by mohol nasvedčovat aj geofyzikálne získaný pôdorys. V pol'ských kláštoroch Koprzywnica a Wachock, ktoré mohli slúžit ako stavebný vzor opátstva v Štiavniku (Slivka 1991, 104), boli hypokaustá doložené pod refektármi (Bingenheimer 1998, 382; Kwiatkowska-Kopka 2011, 69, 74).

K datovaniu zariadenia sa možno vyjadrit len hypoteticky. Pravdepodobne mohlo byt’ súčastou kláštora vybudovaného po požiari v roku 1260 a dokončeného zrejme $\mathrm{v}$ 14. stor. $\mathrm{V}$ prípade výstavby zariadenia ešte v 13. stor. by išlo o najstarší exemplár z územia Slovenska a z typologického hladiska by do úvahy prichádzali staršie hypokaustá II., resp. III. typu podla Bingenheimerovej (1998) typológie. Tie na Slovensku zatial’ nájdené neboli. Spol'ahlivé odpovede na tieto úvahy môže priniest’ až d’alší terénny výskum. Z dosial' realizovaných prác vieme, že v kláštore sa používali aj kachlové pece, doložené nálezmi typologicky starších hrncovitých a miskovitých, ako aj komorových reliéfne zdobených kachlíc z druhej polovice 15. stor., ktoré sa nachádzali po celej preskúmanej ploche kláštora (Kopták 2012, 166-169).

\subsection{Trenčín-Opatová (Vel'ká Skalka), kláštor benediktínov}

Kláštor založil v roku 1224 nitriansky biskup na mieste, kde podla Maurovej legendy žili sv. Andrej - Svorad a Benedikt. Išlo o menší kláštor, ktorého hmotné zabezpečenie nebolo vel'ké. Vizitácia kláštora z roku 1508 ho zachytáva už v stave úpadku. Benediktínsky život v kláštore končí po roku 1528, ked' král' zbavil funkcie posledného opáta a patronátne právo nad kláštorom udelil nitrianskemu biskupovi (Judák 2002, 13-30; Marsina a kol. 1997; Oslanský 1999, 29 n.; Pomfyová 2015, 752, 753; Zmeták 2011).

Areál kláštora je situovaný na strmom svahu a je ohradený z východnej strany. V jeho južnej časti sa nachádza trojposchodová kaplnka, pristavaná ku skalnému zrázu s jaskyňou. Budovu konventu tvoril samostatný objekt, ktorý v jezuitskej fáze (1644-1773) pozostával z dvoch krídel v tvare písmena L, situovaných v juhozápadnej a severovýchodnej časti areálu (obr. 19: 3).

Od roku 1991 sa na lokalite uskutočnila už séria výskumov (Gajdošová/Paulusová 1997; Nešporová 1992; Nipčová 2011). Nová etapa výskumu, ktorá má už systematický charakter, sa realizovala v rokoch 2012 až 2015, pričom pozostávala z archeologického (Horňák/Krištofová 2012; Zachar 2013; Zachar/Horñák 2015; Zachar a i. 2014), ako aj architektonického výskumu (Haviarová/Haviar 2015). ${ }^{44}$

Počas prác v roku 2015 bolo v západnej budove konventu odkryté hypokaustum. ${ }^{45}$ Nachádzalo sa v juhovýchod- nom nároží južnej miestnosti (obr. 19: 1). Zariadenie bolo vo vel'mi dobrom stave $s$ takmer kompletne zachovanou konštrukciou pece a len čiastočne ho narúšali dve, údajne recentné, jamy. $Z$ tohto dôvodu nebolo možné bližšie preskúmat’ a zdokumentovat’ vnútro hypokausta.

Vonkajší plášt zariadenia tvorila obdížniková komora s rozmermi 2,85 x 1,9 m, vymurovaná z lomového kameňa kladeného na hlinu (obr. 19: 2, 4). Jeho západná stena sa smerom nadol schodovite rozširovala. Celková šírka západnej steny bola 0,51 m a severnej 0,57 m. Z južnej aj východnej strany sa zariadenie opieralo o obvodové steny budovy (obr. 19: 1, 2, 4) len vnútorným pláštom, vyhotoveným $z$ tehál $(25 \times 10 \times 7 \mathrm{~cm}) \cdot{ }^{46}$ Do neho bol ukotvený rošt, ktorého rebrá tvoril zdvojený klenbový pás tehál (obr. 19: 5, 6). Na rošte bola uložená vrstva riečnych kameňov s vel'kostou cca do $20 \mathrm{~cm}$. Stopy od sadzí niesli najmä kamene zo spodných vrstiev. Dobrý stav zariadenia umožňuje sledovat spôsob uloženia vrstvy okruhliakov na rošt. Medzery medzi rebrami sú vyložené väčšími kameňmi, vd’aka čomu menšie neprepadávajú nadol (obr. 19: 5).

Na korunu vonkajšieho aj vnútorného plášta pece dosadal zhora riadok tehál, spájaný už maltou (obr. 19: 2, 6). Sledovat ho bolo možné len na západnej, najlepšie zachovanej stene. Táto konštrukcia sa konzistentne nakláňala smerom dovnútra pece a indikuje, že zariadenie mohlo byt nad tepelno-akumulačnou vrstvou zaklenuté d’alšou klenbou, na ktorú by dosadali podlahové platne so vzduchovodmi. Pri takejto rekonštrukcii je možné, že hypokaustum vystupovalo do istej miery nad úroveň podlahy v interiéri. Na základe dochovaných zvyškov však nemožno presnejšie odhadnút výšku potenciálnej klenby.

Obslužný priestor zariadenia zatial' odkrytý nebol. Pravdepodobne sa nachádzal na južnom konci hypokausta, čo indikuje prerušené murivo pôvodnej priečky, ktoré bolo pri novovekej prestavbe kláštora zamurované (obr. 19: 1, 4; Zachar/Horñák 2015, 21-29, 35 n., 39 nn.).

Stavebný kontext zariadenia je pomerne zložitý. Podla doterajších výsledkov možno s istotou konštatovat', že hypokaustum bolo založené do vrstiev (SJ 133) obsahujúcich keramiku z 13., v jednom prípade možno až zo 14 . stor. (Zachar/Horňák 2015, 28, 36, 41, tab. 3: 4-6, výkres 12 A-B). Zariadenie zhora prekrývala vrstva (SJ 111) obsahujúca neskorostredoveký materiál, ktorý možno datovat najneskôr od druhej polovice 15. stor. (Zachar/Horňák 2015, 22, 35, 40, výkres 8 ; obr. $5-8$; tab. 2: 2-3; 6; 3: 1-3) ${ }^{47}$ Severnú čast' pece prekrývala okrem toho aj priečka, stavebno-historickým výskumom datovaná do 16. stor. (obr. 19: 1, 2, 4; Haviarovál Haviar 2015, 20, 25 nn.). Ked’že zasahovala aj nad vnútornú čast’ pece s roštom a potenciálnu klenbu usudzujeme, že $\mathrm{v}$ tejto stavebnej fáze už zariadenie nemohlo fungovat.

\footnotetext{
${ }^{44}$ Ďakujem M. Haviarovej a T. Haviarovi za poskytnutie výskumnej dokumentácie.

${ }^{45}$ Ďakujem M. Horňákovi a J. Zacharovi za poskytnutie dokumentácie a možnost’ publikovat nález.

${ }^{46}$ Podla stavebno-historického výskumu je východný obvodový múr budovy datovaný do stredoveku (prvá a druhá stavebná fáza - Haviarová/Haviar 2015, 24 n.). Podla nášho názoru by však murivo mohlo pochádzat až zo 17. stor. Z písomných prameňov sa dozvedáme, že: „Roku 1672 na mieste zničeného múru, ktorý z východnej strany obopínal obydlie starej rezidencie, vystavali od základu nový múr..." (Pachanská/Hlavačková 1993, 4, cit. podla: Haviarová/Haviar 2015, 26). V prospech tejto interpretácie hovorí aj pozorovanie, že žiadna so starších; priečok nie je previazaná s obvodovým murivom. Obvodový múr má najvyššiu niveletu základového odskoku, ktorá koreluje s poslednou barokovou pochôdznou úrovňou. Murivo je velmi tesne pristavané k vnútornému pláštu hypokausta, takže sa javí, že ho mohlo aj čiastočne porušit' (obr. 19: 1, 4). V dôsledku toho nevieme s istotou povedat', ako pôvodne vyzerala východná stena hypokausta a či pozostávala len z vnútorného plášta.

${ }^{47}$ Ide o materiál s redukčným, tvrdým výpalom z dobre plavenej hliny. Keramika je robená na rýchlo rotujúcom kruhu a zrezávaná strunou. V súbore sa nevyskytuje glazúra.
} 


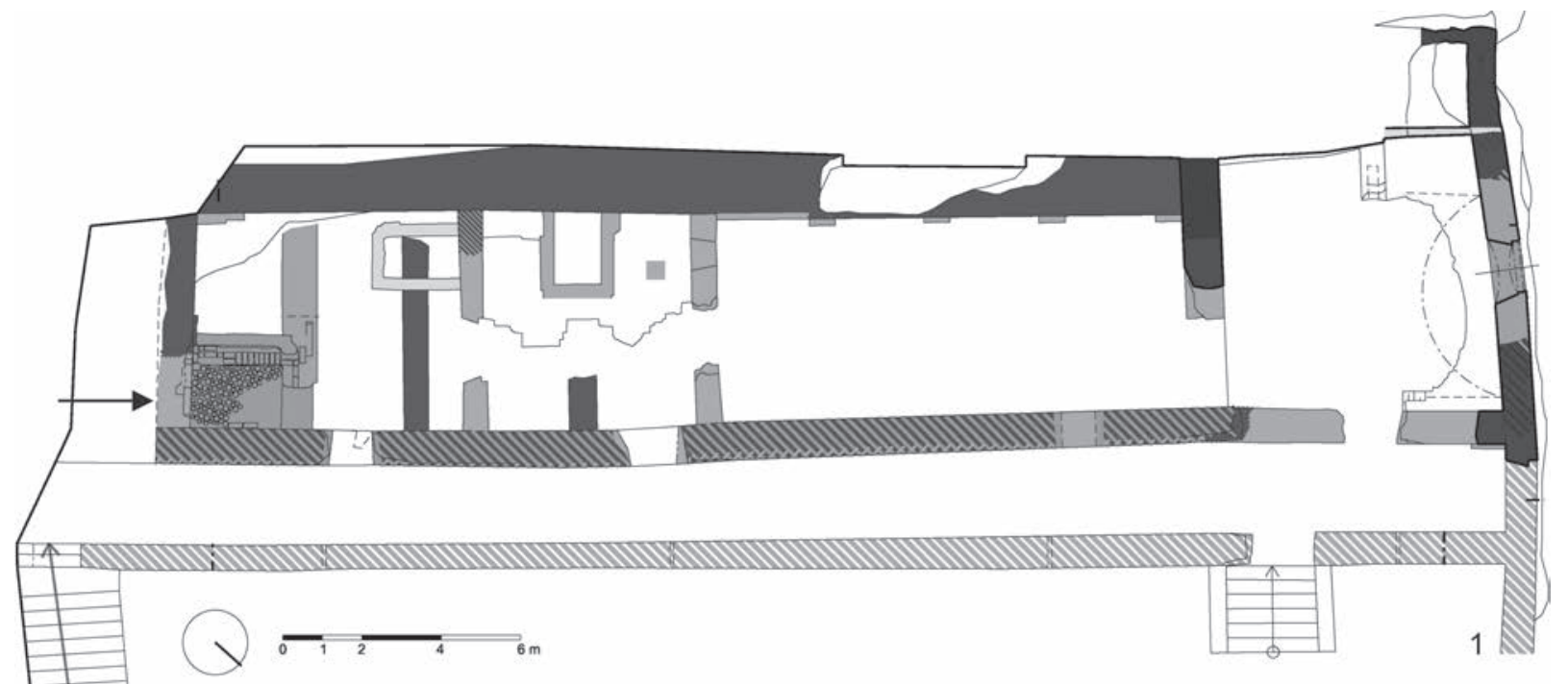

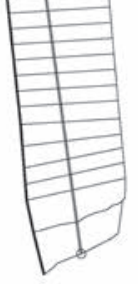
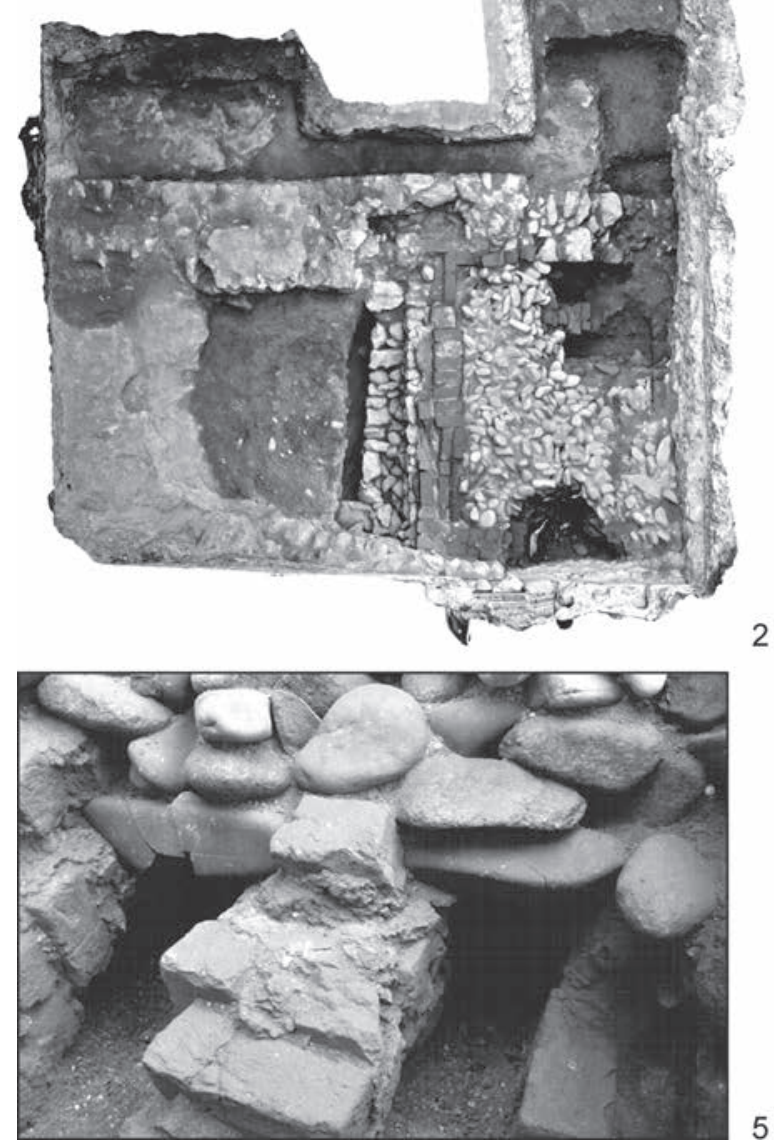

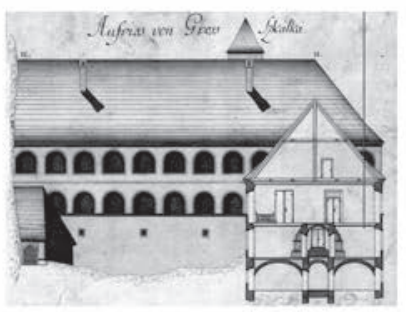

3

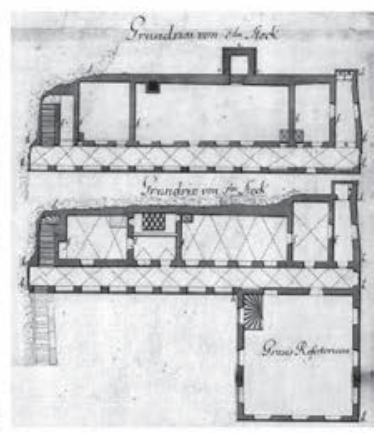

4

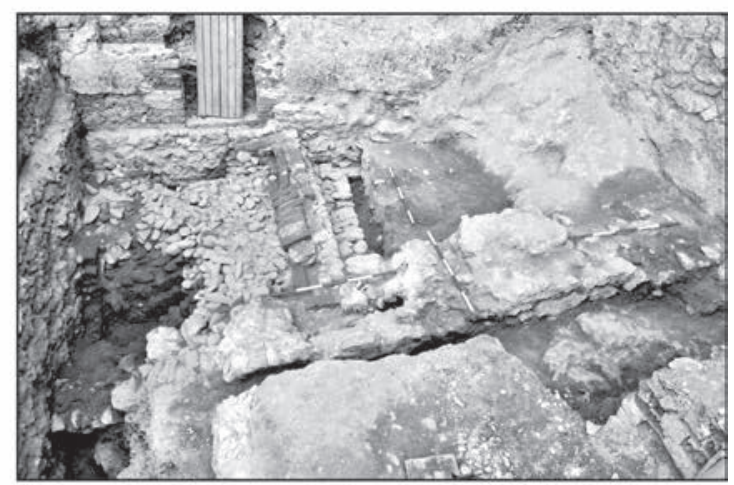

6

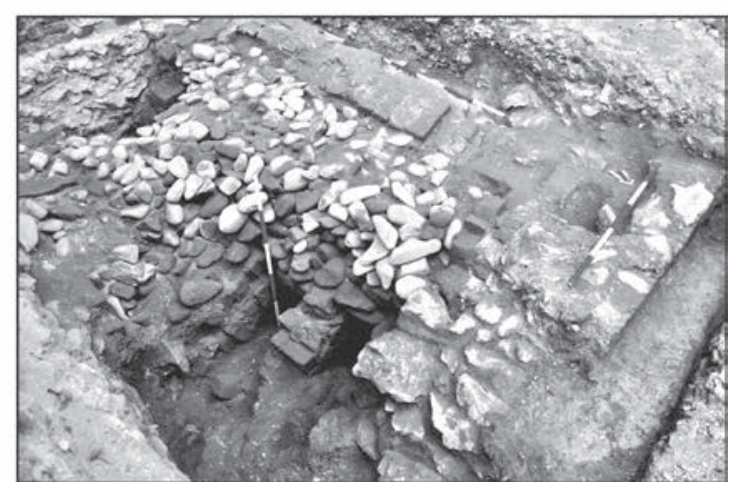

Obr. 19. Trenčín-Opatová (Vel'ká Skalka), kláštor benediktínov. 1 - pôdorys západnej budovy kláštora s vyznačenou polohou zariadenia (podla Haviarová/Haviar 2015); 2 - pohlad zhora na pec; 3 - pôdorys a rez budovou kláštora po jezuitskej prestavbe z roku 1783, úroveň druhého a tretieho poschodia konventu (podla Várady 1783); 4 - pohlad na zariadenie a vykurovanú miestnosṫ; 5, 6 - detail roštu pece a tepelno-akumulačnej vrstvy okruhliakov (2, 4-6 podla Zachar/Horňák 2015). 
Z písomných prameňov vieme, že vizitácia z roku 1508 našla kláštor $\mathrm{v}$ stave úpadku, pričom sa uvádza, že jeho správca prislúbil vizitátorom opravu kláštora, jedálne a ciel (Marsina 1997, 98). Najneskorší dátum zániku hypokausta prichádza do úvahy po roku 1528, kedy po odchode mníchov prebývalo v kláštore vojsko, ktoré na objekte uskutočnilo stavebné úpravy (Haviarová/Haviar 2015, 25 n.).

Na základe stavebno-historického výskumu môžeme povedat', že zariadenie vykurovalo štvorcový priestor $\mathrm{s}$ rozmermi 5,4 x 5,3 m (28,7 $\left.\mathrm{m}^{2}\right)$. Jeho podlaha sa nedochovala (úroveň 249,21-249,38 m n. m.). V juhozápadnom rohu miestnosti vystupovalo skalné podložie nad úroveň podlahy $(250,16 \mathrm{~m} \mathrm{n}$. m.) a trochu zmenšovalo plochu miestnosti (obr. 19: 1, 2, 4). Funkciu vykurovaného priestoru v dispozične atypickom kláštore je problematické identifikovat'. Presnejšie závery umožní až výskum d’alších častí kláštora, ako aj komplexné spracovanie doterajších výsledkov.

Vzhl'adom na konštrukciu zariadenia môžeme konštatovat', že zariadenie v Skalke predstavuje hypokaustum IV. typu, ktorého výstavbu môžeme zaradił do rámca 14. až 15. stor. K zániku zariadenia došlo možno už v priebehu 15. stor., najneskôr však v prvej polovici 16. stor.

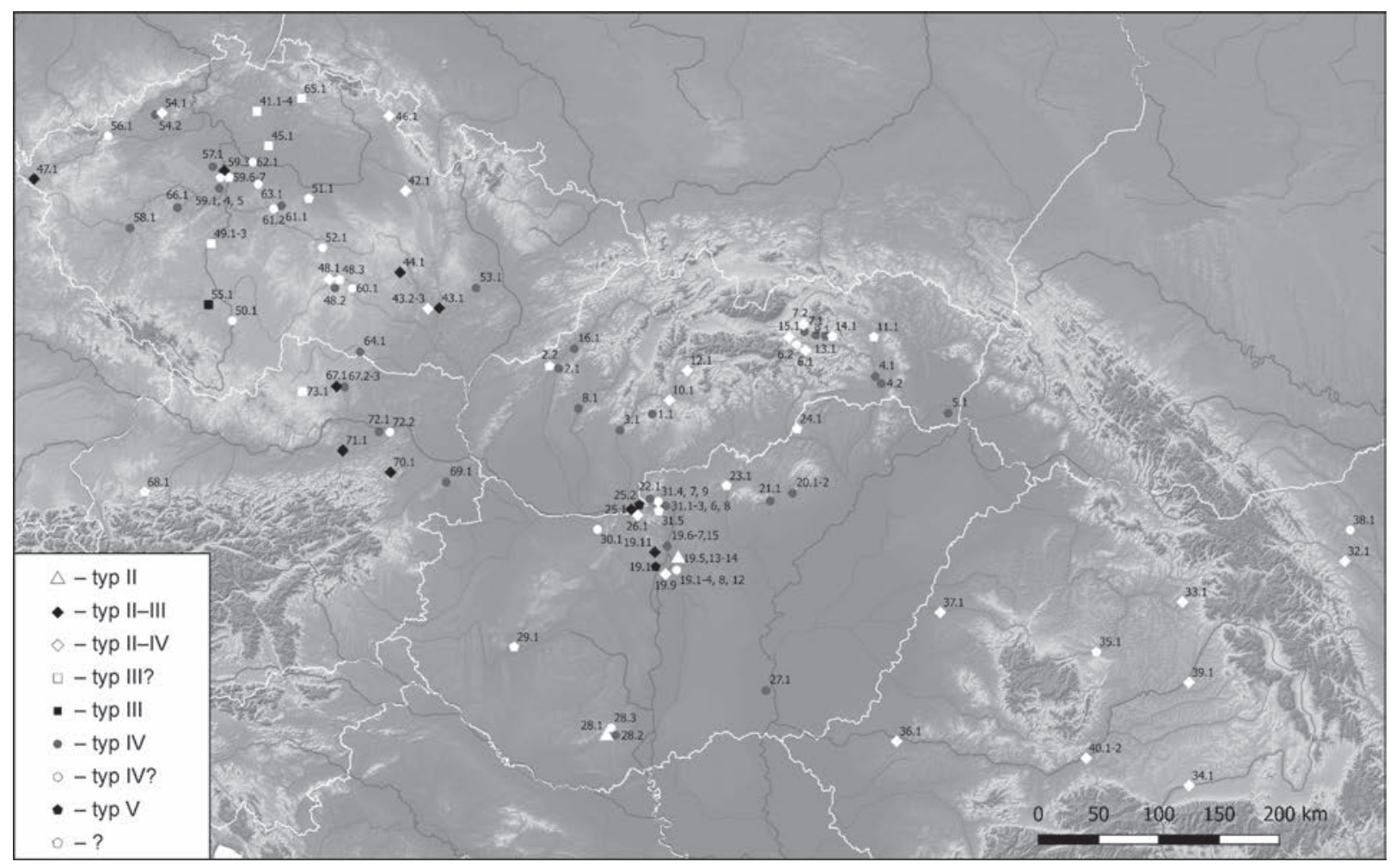

Obr. 20. Distribúcia stredovekej teplovzdušnej vykurovacej technológie v juhovýchodnej časti strednej Európy (podla Hanuš 2016, upravené). 1.1 - Banská Štiavnica, dominikáni; 2.1 - Beckov, hrad; 2.2 - Beckov, hrad; 3.1 - Hronský Beňadik, benediktíni; 4.1 - Košice, dominikáni; 4.2 - Košice-Krásna, benediktíni; 5.1 - Leles, premonštráti; 6.1 - Letanovce, kartuziáni; 6.2 - Letanovce, kartuziáni; 7.1 - Levoča, meštiansky dom; 7.2 - Levoča, meštiansky dom; 8.1 - Ludanice, benediktíni; 9.1 - Nemešany, panský dvorec; 10.1 - Petuša, hrádok; 11.1 - Prešov, Caraffova väznica; 12.1 - Slovenská L'upča, františkáni; 13.1 - Spišské Podhradie, Pažica; 14.1 - Spišský hrad; 15.1 - Spišský Štiavnik, cisterciáni; 16.1 - Trenčín-Opatová (Vel’ká Skalka), benediktíni; 19.1-4, 8, 12 - Budapešt', hrad; 19.5, 13, 14 - Budapešt', dominikáni; 19.6, 7, 15 - Budapešt', dominikáni; 19.9 - Budapešt', františkáni; 19.10 - Budapešt' (Starý Budín), hrad; 19.11 - Budapešt’ (Starý Budín), františkáni; 20.1, 2 - Jáger, hrad; 21.1 - Kisnána, hrad; 22.1 - Márianosztra-Toronyalja, pavlíni; 23.1 - Mátraszőlős, Kisvár; 24.1 - Mohosváron, hrad Kelemér; 25.1 - Ostrihom, hrad; 25.2 - Ostrihom, hrad; 26.1 - Ostrihom, johaniti; 27.1 - Ópusztaszer, benediktíni; 28.1 Pécsvárad, benediktíni; 28.2 - Pécsvárad, benediktíni; 28.3 - Pécsvárad, benediktíni; 29.1 - Szigliget, hrad; 30.1 - Tata, hrad; 31.1-3, 6, 8 - Vyšehrad, palác; 31.4, 7, 9 - Vyšehrad, palác; 31.5 - Vyšehrad, palác; 32.1 - Baia, Katedrála Sf. Fecioară; 33.1 Bistrița, dominikáni; 34.1 - Cârța, cisterciáni; 35.1 - Cluj-Napoca; 36.1 - Frumuşeni, benediktíni; 37.1 - Oradea, františkáni; 38.1 - Suceava, hrad; 39.1 - Târgu Mures, františkáni; 40.1, 2 - Vinţu de Jos, dominikáni; 41.1-4 - Bezděz, hrad; 42.1 - Brandýs nad Orlicí, hrad; 43.1 - Brno, minoriti; 43.2, 3 - Brno, minoriti; 44.1 - Bukov, hrad; 45.1 - Dražice, hrad; 46.1 - Vízmburk, hrad; 47.1 - Cheb; 48.1 - Jihlava, minoriti; 48.2 - Jihlava, minoriti; 48.3 - Jihlava, dom č. p. 57; 49.1-3 - Kamýk, hrad; 50.1 Karlshaus, hrad; 51.1 - Kutná hora, Sankturinovský dom; 52.1 - Lipnice nad Sázavou, hrad; 53.1 - Melice, hrad; 54.1 - Most, minoriti; 54.2 - Most, minoriti; 55.1 - Myšenec, hrad; 56.1 - Nový Šumburk, hrad; 57.1 - Okoř, hrad; 58.1 - Plzeň, minoriti; 59.1, 4, 5-Praha, hrad, palác; 59.2 - Praha, dom biskupa; 59.3 - Praha, benediktínky; 59.6, 7 - Praha, klarisky; 60.1 - Rokštejn, hrad; 61.1 - Sázava, benediktíni; 61.2 - Sázava, benediktíni; 62.1 - Stará Boleslav, bazilika sv. Václava; 63.1 - Škvorec, hrad; 64.1 - Vranov nad Dyjí, hrad; 65.1 - Zbiroh, hrad; 66.1 - Žebrák, hrad; 67.1 - Altenburg, benediktíni; 67.2, 3 - Altenburg, benediktíni; 68.1 - Attersee; 69.1 - Bruckneudorf, cisterciáni; 70.1 - Heiligenkreuz, cisterciáni; 71.1 - Sankt Pölten, augustiniáni; 72.1 - Tulln, dominikáni; 72.2 - Tulln, dominikánky; 73.1 - Zwettl, cisterciáni. 


\section{VYHODNOTENIE}

\section{Základná charakteristika súboru}

Celkovo sme na území Slovenska identifikovali 20 potenciálnych exemplárov teplovzdušných pecí na 16 lokalitách (obr. 20). O niektorých nálezoch však musíme hovorit kvôli nedostatku presnejších informácií, resp. ich diskutabilnej povahe len s opatrnostou. Konkrétne ide o druhú pec v Letanovciach-Kláštorisku (6.2) a druhý objekt na hrade Beckov (2.2). Ešte väčšmi obozretný musíme byt pri peci zo Spišského hradu (14.1), ktorému chýba súdobý obytný architektonický kontext a Caraffovej väznici v Prešove (11.1), kde je potrebný doplňujúci výskum. V prípade piatich lokalít disponujeme len nálezmi podlahových platní (6.1 Letanovce, 7.2 Levoča, 10.1 Pet’uša, 12.1 Slovenská L’upča, 15.1 Spišský Štiavnik), ktoré však existenciu hypokaust bezpečne dokladajú. Odkrytých a spol’ahlivo identifikovaných teplovzdušných pecí evidujeme 11 (kat. 1.1, 2.1, 3.1, 4.1, 4.2, 5.1, 7.1, 8.1, 9.1, 13.1, 16.1). Celkovo tak na území Slovenska môžeme hovorił minimálne o 16-tich doložených stredovekých exemplároch.

Zo získaného súboru je vidiet, že nálezy sa vyskytujú vo viacerých regiónoch Slovenska, pričom v oblasti Spiša sa črtá koncentrácia a naopak na juho- a severozápadnom Slovensku badat' ich absenciu (obr. 20). Vzhl'adom na výskyt hypokaust v okolitých regiónoch (Hanuš 2016) túto medzeru v zastúpení možno pravdepodobne považovat' za stav bádania.

\section{Typológia}

Všetky odkryté a spol'ahlivo identifikovatelné pece patria typologicky do IV. skupiny podla typológie K. Bingenheimera (1998, 146-171, 248-403, mapa 3), ktorý možno označit ako teplovzdušné vykurovanie s tepelným zásobníkom (Steinkammer-Luftheizung). Tieto zariadenia pozostávali z pece situovanej pod vykurovanou miestnostou, ktorá bola preklenutá viacerými klenbovými pásmi vytvárajúcimi rošt. Na ňom bola poukladaná vrstva kameňov, obvykle riečnych okruhliakov (obr. 21). Tento prvok zväčšoval tepelnú, akumulačnú a následne výhrevnú schopnost̉ pece. Prevádzka zariadenia prebiehala v dvoch fázach. Počas horenia bol otvorený komín, ktorý odvádzal splodiny z komory. Po uhasení a odvetraní sa prístup do komína uzavrel a otvorili sa prieduchy v podlahe. Tie vpustili do miestnosti teplý vzduch, ohriaty rozpálenou pecou.

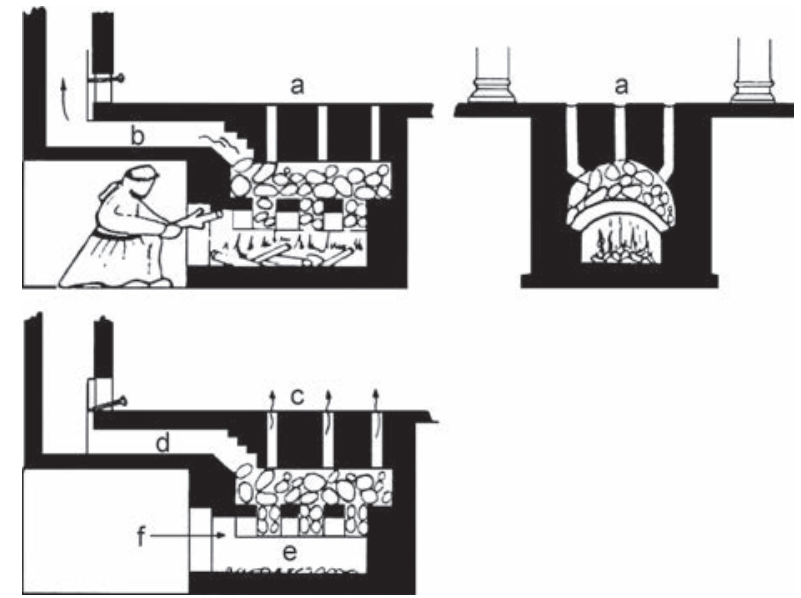

Obr. 21. Schéma obsluhy teplovzdušnej pece IV. typu s tepelným zásobníkom (podla Hawel 1993). Legenda: a - prvá fáza, horenie; b - otvorený komín; c - druhá fáza, vykurovanie; d - uzatvorený komín; e - uhasený oheň; $\mathrm{f}$ - čerstvý vzduch.

Pôvod tohto konštrukčného riešenia sa hl’adá $\mathrm{v}$ súvislosti s tradíciou kúpelnej pece $\mathrm{v}$ pobaltskej oblasti. Prvý raz je identifikovaný v prvej tretine 14. stor. v prostredí rádu nemeckých rytierov v tomto regióne (Bingenheimer 1998, 196). Jeho použitie sa velmi rýchlo rozšírilo v priebehu 14. stor. Geograficky K. Bingenheimer (1998, mapa 3) výskyt IV. typu ohraničil na juhu alpskou oblastou, na západe riekou Rýn, na severe Škandináviou (Dánsko, Śvédsko, Fínsko) a Estónskom, na východe Polskom a severozápadným okrajom Litvy. $V$ rámci našej dizertačnej práce zameranej na juhovýchodnú čast’ strednej Európy sa nám rozšírenie tohto typu podarilo odsledovat až po východné a južné hranice Uhorského královstva, ako aj za Karpatským oblúkom, v oblasti Moldavského kniežatstva (obr. 20; Hanuš 2016, 65, 66, mapa 1; 4). Na rozdiel od starších typov hypokaust prenikajú pece IV. typu z prostredia cirkevných inštitúcií a feudálnych elít do miest, kde ich nachádzame v bohatých meštianskych domoch a radniciach.

Evolučne starší než IV. typ hypokausta na našom území prichádza do úvahy len hypoteticky $\mathrm{v}$ prípade cisterciánskeho kláštora v Spišskom Štiavniku. Zariadenie, z ktorého zatial' disponujeme len podlahovou platňou, mohlo byt' postavené najskôr po roku 1237, pravdepodobnejšie však až po požiari kláštora v roku 1260. Architektonické články z lokality tu dokladajú stavebné aktivity na kostole až do 80. rokov 13. stor. (Pomfyová 2000-2001, 306; 2003, 618 n.). Starší typ hypokausta by sa mohol teoreticky vyskytnút' v kláštore v Slovenskej L’upči založenom pred rokom 1263, odkial' doposial' rovnako poznáme len podlahové platne. Tieto otázky dorieši až prípadná lokalizácia pecí. 


\section{Datovanie}

Najstaršia doposial' odkrytá teplovzdušná pec pochádza pravdepodobne z dominikánskeho kláštora v Banskej Štiavnici (1.1). Kláštor sa v písomných prameňoch prvý raz spomína v roku 1303 (Ragač 2006, 3). Zariadenie bolo súčastou jeho prvej stavebnej fázy, ktorá sa podla súčasného stavu bádania kladie do širšieho rámca poslednej štvrtiny 13. stor. (po roku 1275) až prvej polovice 14. stor.

Nález z Banskej Štiavnice môže poukazovat’ na skorší vznik a rozšírenie IV. typu. V prospech toho hovoria aj d’alšie pece $\mathrm{z}$ územia Uhorska a to z rádovej školy dominikánov v Budíne datovanej na základe keramiky, mincí a písomných prameňov do krátkeho intervalu medzi roky 1304 až 1305 (H. Gyürky 1981, 102 n.), ako aj nález série hypokaust z královského sídla vo Vyšehrade, ktoré možno datovat’ medzi roky 1323 až 1330 (Buzás/ Szőke 2000, 121).

K. Bingenheimer $(1998,196)$ pritom datuje celkovo najstaršie exempláre do prvej tretiny 14. stor. z pobaltskej oblasti. Nálezy z Uhorska, ktoré sú možno ešte staršie, tak otvárajú otázku o momente vzniku daného typu pecí, ako aj o jej domovskej oblasti. Uvedené pozorovania každopádne dokladajú, že pece s tepelným zásobníkom sa museli rýchlo rozšírit už v priebehu prvej tretiny 14 . stor. na rozsiahlom území strednej Európy, od Baltiku až po Uhorsko, takže je pravdepodobné, že ich vývoj mohol prebehnút o čosi skôr, už niekedy koncom 13. stor.

Naopak najmladší exemplár z územia Slovenska reprezentuje druhá pec z kartuziánskeho kláštora v Letanovciach (6.2). Situovaná mala byt v objekte postavenom po roku 1500, pričom zariadenie mohlo vzniknút' a fungovat' najdlhšie do roku 1543, kedy kláštor zanikol. Nález je publikovaný len formou stručnej zmienky, takže nevieme presne posúdit’ jeho charakter a k danému typu ho zarad'ujeme len hypoteticky. Druhý, taktiež problematický exemplár je hypokaustum známe len z písomných prameňov. Postavené malo byt $\mathrm{v}$ roku $1540 \mathrm{v}$ jednom z priestorov Prešovskej radnice (11.1). Toto zariadenie zatial' nebolo lokalizované. Najmladšia spol’ahlivo identifikovaná a datovaná pec pochádza z dominikánskeho kláštora v Košiciach (4.1). Jej vznik sa kladie do záveru tretej štvrtiny 15. stor. Tieto zistenia upravujú konštatovania K. Bingenheimera $(1998,196)$ aj v prípade otázky zániku IV. typu pecí, nakolko uvádza, že v 15. stor. už neeviduje výstavbu ani jedného exempláru.

Ďalším, z hladiska chronológie zaujímavým exemplárom, je dodnes stojace hypokaustum $\mathrm{v}$ pivnici meštianskeho domu v Levoči (7.1). Identi- fikované prestavby pece naznačujú možnoste, že sa stredoveké zariadenie využívalo ešte $\mathrm{v}$ novoveku, čo mohlo prispiet aj k jeho zachovaniu.

\section{Pec}

Z konštrukčného hladiska mali pece väčšinou obdížnikový, ale niekedy aj takmer štvorcový pôdorys (3.1 Hronský Beňadik, 7.1 Levoča, 9.1 Nemešany). Ich vel'kost' sa pohybuje v pomerne vel'kom rozsahu. ${ }^{48}$ $\mathrm{Z}$ dostupných údajov patria $\mathrm{k}$ malým zariadeniam nálezy z Hronského Beňadika (3.1; 1,21 m²) a Košíc $\left(4.1 ; 1,95 \mathrm{~m}^{2}\right)$. Väčšie boli v Spišskom Podhradí $\left(13.1 ; 3,04 \mathrm{~m}^{2}\right)$, Nemešanoch $\left(9.1 ; 4,2 \mathrm{~m}^{2}\right)$, Levoči (7.1; $\left.4,57 \mathrm{~m}^{2}\right)$, Ludaniciach $\left(8.1 ; 4,84 \mathrm{~m}^{2}\right)$, Košiciach-Krásnej $\left(4.2 ; 5,69 \mathrm{~m}^{2}\right)$, Trenčín-Opatová $\left(16.1 ; 7,36 \mathrm{~m}^{2}\right)$ a Spišskom hrade $\left(14.1 ; 7,47 \mathrm{~m}^{2}\right)$. Najväčšie v Banskej Štiavnici (1.1; zachované: $6,46 \mathrm{~m}^{2}$, rekonštruované: $\left.10,75 \mathrm{~m}^{2}\right)$ a Beckove $\left(2.1 ; 10,5 \mathrm{~m}^{2}, 2.2 ; 11,84 \mathrm{~m}^{2}\right)$.

Architektúru pecí tvorili väčšinou jednoduché steny. Vo Vel'kej Skalke pri Trenčíne (16.1; obr. 19: 2, 4), Košiciach (4.1; obr. 5: 6) a Beckove (2.1; obr. 2: 5) sa vyskytli pece so zdvojenou konštrukciou. V Skalke a Košiciach bol vonkajší plášt vymurovaný z kameňa a do jeho vnútra bola vstavaná pec $z$ tehál. V Beckove vonkajší plášt̀ vymurovali z kameňa spájaného maltou a vnútorný plášt taktiež z kameňa, avšak kladeného na hlinu. Takéto stavebné riešenie mohlo mat lepšie tepelno-akumulačné, ako aj izolačné vlastnosti. Podobné riešenie poznáme napr. z minoritských kláštorov v Moste (Klápště/Muk/Bubeník2010, 444, 445) a Jihlave (Dvořák a i. 1998; Zatloukal 1996).

Podlahu pecí tvorilo väčšinou len zrovnané podložie. Vyskytli sa ale aj riešenia vyložené tehlami (5.1 Leles, 7.1 Levoča, 9.1 Nemešany, 14.1 Spišský hrad). Kúrenisko bolo väčšinou v rovnakej výške ako obslužný priestor, ale v Levoči (7.1) a Nemešanoch (9.1) bola úroveň kúreniska odsadená vyššie. $\mathrm{V}$ prípade pece $\mathrm{v}$ Beckove (2.2) bola podlaha prekvapivo situovaná nižšie, k čomu poznáme analógiu napr. z hradu Vranov nad Dyjí (Konečný 1983, 449-453; Radová-Štiková 1981, 68, 69).

Horná čast' hypokaust bola väčšinou najviac poškodená a preto môžeme zaklenutie pecí nad roštom predpokladat', aj to len v náznakoch, len v Skalke pri Trenčíne (16.1). Vo viacerých prípadoch sa nám však javí, že pece nemuseli byt̉ zhora zaklenuté, ale podlahové platne mohli dosadat priamo na obvodové steny pece a vrstvu kameňov. Existenciu takéhoto stavebného riešenie spolahlivo potvrdzuje napr. pec z Vyšehradu, Széchenyi utca 25 (Gróf/Kováts 2014, 187-193, 196), ktorá sa výnimočne zachovala aj s podlahovými platňami in situ.

\footnotetext{
${ }^{48}$ Udávaná je plocha definovaná vonkajším okrajom vykurovacej komory, t. j. aj s pláštom pece.
} 
Na dochovaných peciach môžeme sledovat' dve riešenia vstupov. Vo väčšine prípadov evidujeme exempláre s uzatváratelným vstupom (3.1 Hronský Beňadik, 4.1 Košice, 7.1 Levoča, 9.1 Nemešany, 13.1 Spišské Podhradie). Ten tvorili ostenia vyhotovené $\mathrm{z}$ väčších opracovaných kamenných článkov s vysekanou drážkou na osadenie kvadratických dvierok (napr. obr. 9: 6). V niektorých prípadoch sa na nich zachovali aj stavebné kovania. Uzatváratel'ný vstup umožňoval udržiavat čistejší vzduch v obslužnom priestore. $V$ menšom počte bol doložený len jednoduchý vstup do pece, bez stôp po uzatváracom systéme (1.1 Banská Štiavnica, 2.1 Beckov, 4.2 Košice-Krásna, 8.1 Ludanice; napr. obr. 11: 4).

Odvod dymu a s tým spojená regulácia je vzhladom na stav zachovania hornej časti pecí najmenej zdokumentovaným konštrukčným prvkom. Odvod priamo z pece pomocou napojeného komína, resp. dymovodu vieme doložit pri piatich zariadeniach. Pri tom mohol byt' osadený na bočnej (4.2 Košice, 7.1 Levoča, 9.1 Nemešany), čelnej (2.1 Beckov, 3.1 Hronský Beňadik), ako aj zadnej strane (mimo územia Slovenska napr. Vyšehrad, Horný hrad; Feld 2006, 103, pozn. 33). Mimo nášho územia poznáme aj príklady nepriameho odvodu splodín, kedy bol dym odvádzaný najprv z pece čelnou stenou do obslužného priestoru a odtial' pokračoval bud' vol'ne, alebo akýmsi (nezachovaným) potrubím do oddelene situovaného dymovodu (napr. Vranov nad Dyjí; Konečný 1983, 449-453).

Prívod čerstvého vzduchu bol zabezpečený vo všetkých identifikovatelných prípadoch cez čelnú stenu, a to bud' cez vstup do pece, alebo cez menší otvor situovaný nad ním. Ten máme doložený len v prípade pece z Hronského Beňadika (3.1, obr. 4: 5, 6). Pre časté poškodenie hornej časti pecí nevieme povedat', či d’alšie zariadenia ním boli vybavené (mimo územia Slovenska vieme na vel'kom súbore len $\mathrm{v}$ troch prípadoch $\mathrm{s}$ istotou vylúčit, že ho nemali; Hanuš 2016, 45). Pri interpretácii jeho funkcie sa ponúkajú viaceré alternatívy. Prvou mohlo byt zabezpečenie prístupu $\mathrm{k}$ hornej časti pece s akumulačnou vrstvou, čo umožňovalo jej čistenie, opravu a dopĺn̆anie riečnych kameňov. Tie mohli v priebehu času pod vplyvom žiaru praskat’ a prepadávat' cez rošt (Tvauri 2009, 67). Tento účel možno predpokladat' len $v$ prípadoch, kde bol otvor dostatočne vel'ký ako napr. v Hronskom Beňadiku (3.1). Mimo územia Slovenska poznáme ale aj príklady s malými okrúhlymi otvormi, ktoré túto úlohu plnit nemohli (napr. pec v dominikánskom kláštore v Budapešti; H. Gyürky 1981, 82 nn., 86, 102 n.). Tu prichádzajú do úvahy iné funkcie. Otvor mohol slúžit na už spomínaný odvod dymu z pece do obslužného priestoru vo fáze horenia, čo sa ponúka najmä v prípade, ked’ nie je doložený komín, resp. dymovod priamo napojený na pec. Nakol'ko však poznáme prípady, kedy malo hypokaustum okrem horného otvoru aj zabezpečený osobitný odvod dymu (napr. hrad Žebrák; Radová-Štiková 1981, 68, obr. 3), ponúka sa jeho tretia funkcia. Tú predstavuje prívod čerstvého vzduchu k tepelno-akumulačnej vrstve po uhasení ohňa, $v$ druhej fáze prevádzky. Takto sa vzduch vyhol kúrenisku v dolnej časti pece, kde by sa mohol znečistit. Z uvedeného vyplýva, že otvor nad vstupom mohol plnit niektoré, prípadne aj všetky tri funkcie (oprava roštu, odvod splodín, prívod čistého vzduchu), v závislostí od rôznych konštrukčných riešení, v ktorých sa vyskytoval.

$\mathrm{V}$ prípade pecí IV. typu plnila funkciu vykurovacej komory predovšetkým horná čast pece s roštom, ktorý sa dochoval len výnimočne. Počet jeho rebier sa prirodzene odvíjal od vel'kosti pecí. Najlepšie zachované exempláre boli vo Vel'kej Skalke pri Trenčíne (16.1) a Banskej Štiavnici (1.1) ktoré mali po štyri rebrá. Len dva pásy mala malá pec v Košiciach (4.1). Najväčší počet rebier (devät') poznáme z vel'kej pece v biskupskom paláci v Jágri (Giber 2008, 54, 56 n., 79 n.). Ukotvenie roštu $\mathrm{v}$ stenách pece bolo riešené rôznym spôsobom. Bud' vychádzali organicky priamo z bočných stien (napr. 4.1 Košice, 4.2 Košice, 5.1 Leles, 8.1 Ludanice), alebo v nich bol vyformovaný odskok, na ktorom ho založili (3.1 Hronský Beňadik, 7.1 Levoča). Osobitný prípad nachádzame aj vo Vel'kej Skalke pri Trenčíne (16.1), kde boli klenbové pásy zosilnené dvojitou vrstvou tehál (obr. 19: 5, 6). Pri výstavbe roštu boli ako stavebný materiál jednoznačne preferované tehly, použité často aj pri hypokaustách, inak vymurovaných len $\mathrm{z}$ kameňa. Ojedinelé riešenie $\mathrm{v}$ tejto súvislosti predstavuje rošt pece z Banskej Štiavnice (1.1), ktorý bol vyhotovený z vel'kých kamenných oblúkových segmentov (obr. 1: 5, 6).

Ako tepelný akumulátor slúžila vrstva riečnych kameňov. Domnievame sa, že ich výhoda spočívala v tom, že vd’aka oblému tvaru vytvárali medzi sebou vol'ný priestor, kadial' mohol prenikat' vzduch. Okrem toho, ked’̌̌e pochádzali z tvrdých hornín, v prvej fáze síce pôsobili skôr ako tepelný izolátor ale po rozpálení dlho udržiavali akumulované teplo. V prípade viacerých roštov s väčšími rozostupmi vzniká otázka, ako mohli niest' vrstvu často i menších riečnych kameňov. K. Bingenheimer $(1998,173)$ uvádza, že tento problém mohol byt̉ riešený platňami uloženými na rošte. Takáto možnost’ prichádza do úvahy v Banskej Štiavnici (1.1), kde boli pásy údajne prekryté plochými dlaždicovými kameňmi. Plochý kameň sa vyskytol aj na rošte pece v Lelesi (5.1; obr. 7: 2).

V stavebných riešeniach hypokaust sledujeme istú variabilitu aj z hl’adiska materiálu. Konštrukcia výlučne a prevažne $\mathrm{z}$ tehál, charakteristická pre 
IV. typ hypokaust, sa vyskytla v štyroch prípadoch (4.1 Košice, 4.2 Košice-Krásna, 5.1 Leles, 8.1 Ludanice). Mimochodom tehly plevovky, z ktorých bolo vybudované zariadenie $\mathrm{v}$ Ludaniciach poukazujú, že s ich produkciou je potrebné počítat', aspoň v dedinskom prostredí, do prvej polovice 14. stor. Zvyšné hypokaustá zväčša kombinovali kameň a tehlu. $\mathrm{V}$ prípade minimálneho zastúpenia tehly sa použila aspoň na konštrukciu klenbových pásov roštu (7.1 Levoča, 13.1 Spišská Kapitula). Atypický variant predstavuje, ako už bolo spomenuté, zariadenie z Banskej Stiavnice (1.1) a zrejme aj z Nemešian (9.1), vybudované len z kameňa. Výber stavebného materiálu sa najskôr odvíjal od geografického prostredia.

Ako spojivo sa v konštrukcii hypokaust používal íl, predovšetkým vo vnútornej časti pece, ktorá prichádzala do styku s ohňom. Malta sa použivala len výnimočne, a to vo vonkajšom plášti pece, alebo v konštrukcii obslužného priestoru, kde neprichádzala priamo do kontaktu s ohňom, ktorý by ju degradoval. Tento konštrukčný detail pekne ilustruje napr. hypokaustum v Levoči (7.1; obr. 9: 6).

Prevádzka pece opotrebovávala a časom si vyžiadali opravy, prestavby, resp. ich úplnú náhradu. V súbore zo Slovenska evidujeme len špecifickú prestavbu pece $\mathrm{v}$ dominikánskom kláštore $\mathrm{v}$ Banskej Štiavnici (1.1) súvisiacu až s jej vyradením z prevádzky. V podlahe pece bol vyhotovený zahíbený kanál (obr. 1: 6), ktorý zrejme riešil problém s odvodom spodnej vody. K tejto úprave muselo dôjsţ ešte pred zasypaním zariadenia.

V tejto súvislosti možno spomenút, že teplovzdušný princíp sa uplatňoval aj pri podobných zariadeniach slúžiacich ako sušiarne, či udiarne. Ich analýze sa v tejto práci podrobnejšie nevenujeme. $\mathrm{Na}$ Slovensku sa takýto objekt našiel napr. pri kláštore v Košiciach-Krásnej (Luštíková 2008, 334, obr. 3: 4; 5) a možno aj v západnom krídle kláštora (4.2; obr. 6: 1).

\section{Obslužný priestor}

Konštrukcia zariadenia obvykle pozostávala z dvoch častí: z obslužného priestoru a pece. Hypokaustá osadené v pivnici alebo na prízemí v rámci väčšieho priestoru zväčša nemali osobitne vydelený predpecný priestor, takže objekt tvorila len samotná pec (napr. 2.1 Beckov, 7.1 Levoča). Jednotlivé časti hypokaust boli väčšinou usporiadané lineárne. V niekol'kých prípadoch mala dispozícia tvar písmena L (napr. 1.1 Banská Štiavnica, 4.2 Košice-Krásna, 13.1 Spišské Podhradie), čo sa uplatnilo najmä pri viacdielnych zariadeniach vybavených samostatnou prístupovou chodbou, prípadne aj schodiskom, aké poznáme mimo naše územie (napr. augustiniánsky kláštor v Sankt Pölten; Wühr 1985, 75).
Väčšina hypokaust bola osadená v osobitne vyhĺbenej stavebnej jame. Toto riešenie je charakteristické najmä pre kláštory, kde teplovzdušné pece obvykle vykurovali priestory na prízemí. Toto je zrejme aj príćinou prečo sa $\mathrm{v}$ tomto prostredí najlepšie zachovali. Výnimkou sú dve pece v Letanovciach $(6.1,2)$, ktoré boli situované na prízemí, resp. polosuteréne. Osobitným prípadom je polozapustená pec v kláštore v Lelesi (5.1; obr. 7: 3), vystupujúca do interiéru, ktorý zrejme aj vykurovala. Náznaky, že pec vystupovala nad úroveň podlahy, ale menej výrazne, sa črtajú aj v niektorých d’alších prípadoch (8.1 Ludanice, 16.1 Trenčín-Opatová). Menej často boli teplovzdušné pece osadené na prízemí (2.1 Beckov, 9.1 Nemešany), pričom vykurovali priestory na poschodí. Takéto riešenie sú charakteristické pre palácové stavby na hradoch. Výnimočne je doložené hypokaustum situované $\mathrm{v}$ rámci pivnice, čo nám ilustruje príklad pece $\mathrm{v}$ meštianskom dome $\mathrm{v}$ Levoči (7.1), prípadne $\mathrm{v}$ Beckove (2.2). Taktiež si môžeme všimnút horizontálne situovanie zariadenia $\mathrm{v}$ rámci vykurovaného priestoru. Všetky slovenské exempláre sa nachádzali $\mathrm{v}$ rohu miestnosti, ale mimo nášho územia poznáme aj riešenia, kedy pec vybudovali uprostred miestnosti, alebo v strede kratšej, či dlhšej steny (Hanuš 2016, 50).

Z hladiska obsluhy bývali pece prístupné $\mathrm{z}$ interiéru vykurovanej stavby (2.1 Beckov, 4.1 Košice, 7.1 Levoča, 13.1 Spišské Podhradie), ako aj cez priestor situovaný v exteriéry (1.1 Banská Štiavnica, 3.1 Hronský Beňadik, 4.2 Košice-Krásna, 8.1 Ludanice, 9.1 Nemešany). Zahĺbené hypokaustá bývali zväčša dostupné len jednoduchým rebríkom. Mimo naše územie poznáme, ale aj exempláre zo schodiskom (napr. v kláštore dominikánok Budapešt’; Hanuš 2016, 52; Tóth Feurné 1963).

Zariadenia disponujúce osobitne vymedzeným obslužným priestorom ho mali zväčša vymurovaný. Ojedinele sa vyskytli aj riešenia, kedy ho tvorila len jednoduchá, do zeme zahíbená jama (1.1 Banská Štiavnica, 8.1 Ludanice; napr. obr. 1: 4). Obslužný priestor mával obdížnikový tvar, v Ludaniciach (8.1) sa výnimočne vyskytol priestor vo forme poloblúka. Rozmery obslužných priestorov bývali pomerne malé. Pohybovali sa v rozsahu 1,7 až $6,2 \mathrm{~m}^{2}$ vo väčšine prípadov však do $4 \mathrm{~m}^{2}$ (Hanuš 2016, 52). Zväčša išlo o relatívne menšie miestnosti, v ktorých nebol dostatok miesta na skladovanie väčšieho množstva paliva. V kláštoroch mohli mat' hypokaustá spoločný sklad dreva s kuchyňou, ktorá obvykle susedila s vykurovaným refektárom, prípadne kalefaktoriom, pričom registrujeme aj príklady kedy boli hypokaustá priamo prístupné z kuchyne (napr. kláštor dominikánok v Budapešti; Tóth Feurné 1963; kláštor minoritov v Moste; Klápště/Muk/Bebeník 2010). 


\section{Podlahové platne}

Ďalší konštrukčný prvok, ktorý možno sledovat', je spôsob, akým teplovzdušné zariadenie vyústovalo do vykurovaného priestoru. Na zozbieranej vzorke nálezov sa horná čast’ pecí vo väčšine prípadov nedochovala. Ako vieme, hypokaustá zhora prekrývali podlahové platne s prieduchmi, typicky ležiace $\mathrm{v}$ úrovni podlahy miestnosti. $\mathrm{V}$ prípade Ludaníc (8.1) a Trenčína-Opatovej (16.1) sa javí, že platne s prieduchmi mohli vystupovat' aj o čosi vyššie nad úroveň podlahy miestnosti. S istotou toto riešenie ilustruje nález z Lelesa (5.1), ktorý ma od istej výšky omietnuté steny pece, indikujúce výšku pochôdznej úrovne (obr. 7: 3, 4). Podobné riešenie poznáme napr. z pavlínskeho kláštora v Márianosztre, kde pec vystupovala cca $0,5 \mathrm{~m}$ nad podlahu miestnosti (Miklós 1997, 24 n., 59 n.).

Nálezy podlahových platní sú doložené na deviatich lokalitách (4.1 Košice, 4.2 Košice-Krásna, 6.1 Letanovce, 7.2 Levoča, 9.1 Nemešany, 10.1 Petuša, 12.1 Slovenská L'upča, 13.1 Spišské Podhradie, 15.1 Spišský Štiavnik). Vyhotovené boli z kameňa, výnimočne, v Košiciach-Krásnej (4.2) evidujeme exemplár z terakoty (obr. 6: 5). Platne sa zväčša zachovali vo fragmentoch takže ich ucelenú podobu poznáme zriedkavo.

Podlahové platne, ktoré mali zrejme kvadratickú formu, sú doložené zo Spišského Podhradia (13.1; 45 x ? 31 x 15 cm), Slovenskej L'upče (12.1; obr. 15: 2), Letanoviec $(6.1 ;$ ? 40 x ? 40 x 13-14 cm). Platne podlhovastého tvaru poznáme z Nemešian $(9.1 ; 88$ x 66 x ? cm), Spišského Štiavnika (15.1; obr. 18: 2; ? 97 x 44 x $17 \mathrm{~cm})$ a Košíc $(4.1 ;$ ? x ? 68 × 10,6 cm).

Celkovo sa šírka platní pohybovala medzi 40 až $68 \mathrm{~cm}$. Na dížku sa dochovali len výnimočne a dosahovali rozmery od 40 do $97 \mathrm{~cm}$. Hrúbka platní sa pohybovala medzi 9 až $17 \mathrm{~cm}$. Osobitný prípad predstavuje prekrytie hypokausta v Košiciach-Krásnej (4.2; obr. 6: 5), kde boli pravdepodobne použité menšie pálené dlaždice $\mathrm{s}$ prieduchmi (poznáme len hrúbku fragmentu $11 \mathrm{~cm}$ ). Príklad prekrytia teplovzdušných pecí keramickými dlaždicami sa dobre zachoval napr. v kláštore cisterciánok v Trzebnici v Pol'sku (Soukupová 2015, 87, obr. 50 n.) alebo v Estónskom Tartu (Tvauri 2009, 64).

Na príklade podlahových platní z hradu Ojvín (Kluttig-Altmann 2015, obr. 48) vieme, že otvory vzduchovodov mohli byt' profilované rôznym spôsobom. Na nami sledovanom území predstavovali všetky exempláre len jeden typ lemovaný charakteristickými žliabkami. Ich otvory mali priemer v rozsahu 9 až $14 \mathrm{~cm}$. Vzhladom na fragmentárny stav platní zväčša nepoznáme celkový počet prie- duchov. Nález platní z kláštora v Slovenskej L’upči (12.1) dokladá, že teplo do miestnosti vpúštali minimálne štyri prieduchy.

Zátky, ktoré uzatvárali prieduchy, sa na Slovensku nenašli. V prípade Spišského Podhradia (13.1) A. Vallašek $(1999,65)$ uvažuje, že túto funkciu plnili prepálené keramické nádoby pochádzajúce zo zásypu pece. ${ }^{49}$ Interpretácia je však otázna, keďže túto úlohu plnili obvykle zátky z kameňa, aké sa našli napr. na Budínskom hrade (Szakál 1984, 276; Végh 1983, 74; Zolnay 1976, 215, 216; Zolnay/Szakál 1976), kovové zátky (Boockmann 1994, obr. 230), alebo poznáme aj keramické exempláre (napr. z Estónska; Tvauri 2009, Obr. 10; 11), nie však vo forme nádob.

Teplovzdušné kanály distribuujúce teplo dalej od pece na Slovensku neboli identifikované a aj v európskom materiáli sú doložené len výnimočne (napr. hrad Nový Šumburk; Hanuš 2016, 57-59; Hefner 2010).

\section{Sociálny a architektonický kontext hypokaust}

Z hladiska výskytu teplovzdušných pecí v rámci sociálneho prostredia možno na Slovensku skonštatovat štruktúru známu aj z iných oblastí. Väčšina nálezov pochádza z cirkevného, resp. kláštorného prostredia (11 výskytov). V poradí druhé zastúpenie (pät'krát), nájdeme v stavbách vyššej (2.1, 2 Beckov, 14.1 Spišský hrad), ale aj nižšej šlachty (9.1 Nemešany, 10.1 Petuša). Najmenej exemplárov (tri) je doložených z meštianskeho prostredia (7.1, 2 Levoča, 11.1 Prešov). V prípade nálezu zo Spišskej Podhradia-Pažice (13.1) nie je charakter odkrytého areálu jasný. Vzhladom na jeho umiestnenie sa črtá istá spätost' s cirkevným prostredím a inštitúciou kapituly, prípadne by mohol súvisiet’ so sedriou Spišskej stolice.

Z architektonického hladiska môžeme vo všeobecnej rovine konštatovat', že išlo takmer výlučne o murované stavby. V prípade malého hradu Petuša architektonický kontext zatial' nie je úplne zrejmý, ale pravdepodobne aj tu išlo o murovanú stavbu (10.1; obr. 13). Poznáme však aj príklad drevenej stavby vykurovanej hypokaustom napr. z Vyšehradu, Széchenyi utca 25 (Gróf/Kováts 2014, 187-193, 196).

Z hladiska vel'kosti vykurovaných priestorov vidíme, že teplovzdušné pece sa využívali na vykurovanie miestností s plochou od cca $18 \mathrm{~m}^{2}$ (4.1 Košice) po $82 \mathrm{~m}^{2}$ (2.1 Beckov). Najčastejšie sa vel'kost' priestorov pohybovala $\mathrm{v}$ rozmedzí od 40 do $70 \mathrm{~m}^{2}$ (Hanuš 2016, 85).

\footnotetext{
${ }^{49}$ Nálezy sa nepodarilo dohl’adat.
} 


\section{Kláštory}

V rámci monastickej architektonickej schémy sú všetky slovenské exempláre situované v kláštornom krídle oproti kostolu. Tu sa tradične okrem kuchyne nachádzalo predovšetkým refectorium, teda jedáleň a najneskôr v 12. stor. sa do tohto traktu situuje aj nový samostatný priestor, tzv. calefactorium. Išlo o multifunkčnú, spočiatku jedinú vykurovanú miestnost’ v kláštoroch, ktorá vznikla ako reakcia na kumulujúci sa luxus kláštorov (i v oblasti vykurovania) v rámci reformného mníšskeho hnutia (Bingenheimer 1998, 67-69, 109-113).

V prípade slovenských nálezov sa väčšinou pece nachádzajú v najväčšej miestnosti riešeného krídla, ktoré identifikujeme ako refektár. Plocha miestností sa pohybuje medzi 52 až $58 \mathrm{~m}^{2}$. Vzhl’adom na väčšinový výskyt pecí v jedálňach a obvyklú absenciu vykurovacieho telesa $v$ iných priestoroch sa javí, že táto miestnost' mohla mat' v zime multifunkčný charakter. Prítomnost' kalefaktoria možno teoreticky predpokladat’ v Spišskom Štiavniku, kde pec zatial' nebola odkrytá, nakol'ko je tento prvok charakteristický pre cisterciánsku architektúru (Bingenheimer 1998, 109).

$\mathrm{Z}$ uvedeného rámca vybočujú nálezy z benediktínskeho kláštora vo Vel'kej Skalke pri Trenčíne (16.1) a dominikánskeho kláštora v Košiciach (4.1). Kláštor vo Vel'kej Skalke postavený do strmého svahu predstavuje menší atypický objekt, ktorý nemá štandardný kvadratický pôdorys, takže funkcia jednotlivých priestorov je tažšie identifikovatel'ná. Teplovzdušne vykurovaný priestor mal len cca $20 \mathrm{~m}^{2}$. Vzhladom na výskyt pecí v ostatných benediktínskych kláštoroch predpokladáme, že aj tu by mohlo íst' o refektár.

V prípade dominikánskeho kláštora $\mathrm{v}$ Košiciach išlo o menší priestor s plochou cca $25 \mathrm{~m}^{2}$, zrejme vybiehajúci severne z kvadratúry. Vzhl'adom na jeho rozmer tu pravdepodobne nešlo o refektár, či kalefaktorium a do úvahy prichádza skôr napr. individuálna cela, tzv. camera propia. Nárok na ňu mali v dominikánskych konventoch spočiatku najmä magistri, lektori a provinciáli a po roku 1359, i d’alší oficiáli rehole (Hunčaga 2013, 154 n.).

Špecifická je situácia aj v kartuziánskom kláštore v Letanovciach, ktorý sa odlišuje spôsobom mníšskeho života, ako aj architektonickou formou. Hypokaustá tu boli identifikované $\mathrm{v}$ dvoch objektoch. Jedno v štandardnej pozícii v krídle oproti kostolu (6.2), kde vykurovalo miestnost' na poschodí, druhé bolo situované v objekte pristavanom k vel'kej krížovej chodbe (6.1). Jeden z týchto objektov istotne plnil funkciu refektára, druhý pravdepodobne mohol slúžit ako kapitulná sieň.

Nejasná funkcia areálu pri Spišskej Kapitule (13.1) nám neulahčuje ani identifikáciu vykurovaného objektu. Možno tu len vo všeobecnosti predpokladat jej obytný účel, prípadne d’alšie prídavné funkcie.

\section{Feudálne sídla}

Z feudálnych sídel na území Slovenska disponujeme minimom nálezov, z ktorých navyše len v prípade hradu Beckov (2.1) a panského sídla v Nemešanoch (9.1) máme bližšie informácie o vykurovaných priestoroch. Na hrade Beckov (2.1) išlo o vel'ký priestor na prvom poschodí paláca (obr. 2: 6). V miestnosti s polygonálnym pôdorysom, ktorá zaberala takmer polovicu podlažia $\left(81,41 \mathrm{~m}^{2}\right)$ jednu z hlavných obytných komnát hradu, prípadne aj reprezentačný priestor. Druhá pravdepodobná pec na hrade Beckov (2.2) mohla vykurovat taktiež miestnost' $\left(45,75 \mathrm{~m}^{2}\right)$ na prvom poschodí západného paláca, kde možno rovnako uvažovat' o obytnej, prípadne reprezentačnej funkcii. V Nemešanoch (9.1) hypokaustum pravdepodobne vykurovalo priestor na poschodí stavby pristavanej $\mathrm{v}$ druhej polovici 14. stor. k staršej obytnej veži. Vzhl’adom na stav jej zachovania sa tažko jednoznačne vyjadrit' $k$ jeho funkcii (obr. 12: 1-3). Predpokladáme však, že prístavba najskôr riešila potreby bývania rozrastajúceho sa zalužianského rodu. Slovenské príklady, ako aj d’alšie exempláre zo strednej Európy ukazujú, že hypokaustá vo feudálnych sídlach obvykle vykurovali obytné, niekedy aj reprezentačné priestory na panskom piano nobile. Najvyššiu formu tepelného a obytného komfortu, akú v zimnom období zabezpečovala kombinácia teplovzdušnej technológie s výdrevou zateplenými miestnostami typu Stube, evidujeme zväčša na královských hradoch, zatial len v okolitých krajinách (Hanuš 2016, 77-79).

\section{Meštianske stavby}

O vykurovaní priestorov v meštianskom dome sme bližšie informovaný len v prípade nálezu v Levoči (7.1; obr. 9). Zariadenie tu ohrievalo prízemie prvej kamennej stavby situovanej v híbke parcely. Tvoril ju poschodový a podpivničený jednopriestor (9 × 6,5 m;58,5 m²), ktorý bol pôvodne zrejme napojený na predný drevený dom. Vykurovacie zariadenia a niekedy aj náročnejšie architektonické články vyskytujúce sa pri tomto druhu murovaných objektov jednoznačne dokazujú obytný účel ich prízemia..$^{50}$ $\mathrm{V}$ prípade nadzemného podlažia sa predpokladá

\footnotetext{
${ }^{50}$ Hypokaustum tu bolo postavené sekundárne a možno nahradilo starší krb, obvyklý v tomto type domov v Levoči, ale aj širšom okolí (Oriško 2004, 269; pozri heslo 7.1).
} 
funkcia sýpky a predný dom komunikujúci s ulicou získal po výstavbe murovanej časti zrejme skôr hospodársky význam. Typ dvojitého domu (Doppelhaus) v spišskej meštianskej architektúre má pôvod v saskom prostredí, kde sa rozšíril už v 12. a 13. stor. a predstavoval obydlie vrchnej sociálnej vrstvy vznikajúcich miest. Zadný murovaný dom pritom slúžil ako reprezentatívnejšia krbom vykurovaná obytná sýpka (Wohnspeicher), v prameňoch vystupujúca ako caminata (Oriško 2004, 275-280).

V neskorom stredoveku nachádzame na území od Vestfálska až po Pobaltie analogicky koncipované meštianske stavby tzv. typu Dielenhaus. V prednej časti ich charakterizovala vel'ká a vysoká hala, ktorá mala hospodársku funkciu. Jej prízemie slúžilo ako dielňa, či obchod a v suteréne a na vyšších poschodiach boli skladovacie priestory. Obytná čast' sa nachádzala v nadväzujúcej stavbe v zadnom dvore. Rovnako ju tvoril murovaný objekt, ktorého tradičné pomenovanie Kemlade, sa vyvinulo z pôvodného latinského caminata. Spočiatku sa v rámci neho nachádzala aj kancelária obchodníka, ktorá býva v prameňoch označovaná ako estuarium, Dorntze, či Stube (bližšie k pojmom Atzbach 2014, 200-204; Hanuš 2016, 28, 29). V severonemeckej a pobaltskej oblasti bývali tieto miestnosti často vykurované hypokaustami. Na prelome stredoveku a novoveku sa tieto kancelárie presunuli zo zadného do predného domu, k vstupu z ulice. Následne sa $\mathrm{v}$ tejto časti domov začínajú objavovat aj teplovzdušné pece. V niektorých oblastiach, napr. v Lübecku, sa toto dispozičné riešenie uplatňovalo už od 14 . stor. Naopak v severnejších pobaltských oblastiach zostala kancelária situovaná aj nad’alej $\mathrm{v}$ zadnom dvore (Möller 2006, 47, 49).

V kontexte s uvedeným vývojom možno predpokladat, že teplovzdušná pec z Levoče (7.1) situovaná v zadnej časti dvojdomu vykurovala $\mathrm{v}$ istej fáze hlavný obytný priestor, ktorý mohol slúžit aj ako kancelária majitela domu. Ako vedlajší efekt vykurovania pri tom mohlo byt' aj prípadne sušenie zbožia na poschodí domu. Podobné typy najstarších murovaných jednopriestorových domov situovaných $\mathrm{v}$ híbke parcely sú doložené aj z Trnavy (Žuffová 2009, 48, obr. 15), či Košíc (Rusnák 2011, 167, obr. 20; 21). Doklad ich teplovzdušného vykurovania zatial' zostáva obmedzený na Levoču, kde sa okrem spomínanej pece v dome na Námestí Majstra Pavla č. 31. našla d’alšia podlahová platňa $\mathrm{v}$ zadnom dvore domu č. 40, na opačnej strane námestia.

Ďalšie príklady uplatňovania technológie v mestskom prostredí na nami sledovanom území nachádzame už len v písomných prameňoch. Písomná zmienka sa viaže na väznicu v Prešove (11.1). Potenciálne zaradenie sa tu lokalizuje do tzv. Caraffovej väznice pri mestskej radnici. Hypokaustum malo byt postavené v roku 1540 a využívalo sa, ako naznačujú neskoršie zmienky z rokov 1555 až 1560, na zadržiavanie popredných meštanov. Vzhladom na neskoré datovanie objektu však s istotou nevieme, či pramene naozaj označujú teplovzdušnú pec, i ked' použitá formulácia "vymurovanie hypokausta" by tomu neodporovala. Použitie technológie by isto dávalo zmysel, pretože by väzňovi znemožnilo priamu manipuláciu s ohňom a temperovalo by jeho celu bez d’alšieho vykurovania vd’aka akumulačnej kapacite pece aj niekol'ko dní. V tejto súvislosti je zaujímavá zmienka v diele Správovna od Pavla Žídeka Pražského (1413-1471), kde kvôli bezpečnosti autor odporúča v špitáli, v časti pre „bláznov“, použitie "podzemnej kamenitej pece“ (Reichertová/Radová 1981, 409).

\section{Proces distribúcie a zániku technológie}

\section{Distribúcia technológie}

Najstaršie hypokaustá pochádzajú z kláštorného prostredia, pričom najskôr sa technológia objavuje pravdepodobne $\mathrm{v}$ cisterciánskom kláštore v Spišskom Štiavniku (15.1). Zariadenie, ako bolo spomenuté vyššie, mohlo byt' postavené od poslednej tretiny 13. stor. Podobne od poslednej štvrtiny 13. stor. môže byt̉ datovaná najstaršie odkrytá pec v dominikánskom kláštore v Banskej Štiavnici. Potvrdzuje sa tak pozorovanie, že k rozšíreniu technológie aj na našom území prispeli najmä mníšske rády. Ďalšie exempláre hypokaust z kláštorov ukazujú, že v 14. stor. tvorili hypokaustá ich úplne štandardnú výbavu. Takmer každý kláštor skúmaný v mieste potenciálneho výskytu zariadenia, vykazuje jeho prítomnost'. Z iných sociálnych prostredí nedisponujeme na našom území dostatočným počtom nálezov aby sme mohli detailnejšie sledovat’ proces šírenia technológie. Ako vyplýva z katalógu, výstavba väčšiny odkrytých hypokaust na území Slovenska spadá do 14. stor., pričom najneskôr koncom tohto storočia už je technológia prítomná vo všetkých identifikovaných sociálnych vrstvách. Ako obdobie kulminácie rozšírenia IV. typu hypokaust, ako aj teplovzdušnej technológie všeobecne, sme identifikovali na väčšej vzorke nálezov v strednej Európe druhú až tretiu tretinu 14. stor. (Hanuš 2016, 42). Slovenský korpus nálezov ukazuje, že naše územie zasiahla viac-menej až záverečná vývojová etapa tejto technológie.

\section{Príčiny a proces marginalizácie technológie}

Proces zanechania skúmanej technológie sa začal relatívne skoro. Na území Uhorska môžeme jeho 
počiatok dobre sledovat’ $\mathrm{v}$ král'ovskom paláci vo Vyšehrade. Vel'ké anjouovské kúrie $\mathrm{v}$ areáli neskoršieho královského paláca boli postavené a vybavené hypokaustami po roku 1323, ked’ sa do Vyšehradu prestahoval královský dvor (Buzás 1990, 50, 291, 297, 314, pozn. 97; 1992, 33; 1994, 64; 1995, 13 nn., 14, 17; Buzás/Bodó/Deák 2003, 12-16; Buzás/Laszlovszky/Magyar 2003, 360; Buzás/Szóke 1992, 133; 2000, 119-121; Gróf/Kováts 2014, 192; Mészáros 2008, 95, 115, 238 n., 240, 241; Szőke/Buzás 1994, 124; 2001, 196 n.; Szőke/Búzás/Kocsis 1997, 126 n.; syntéza v Hanuš 2016, 214-219). K ich vyrad’ovaniu ale dochádza už pri prestavbách areálu za vlády L’udovíta I. od 60. rokov 14. stor. (Buzás 2013, 25), čo dokladajú podlahové platne, sekundárne zamurované $\mathrm{v}$ rôznych častiach vznikajúceho královského paláca (Buzás 1990, 50, 291, 297, 314, pozn. 97; 1994, 64; 1995, 11 n., 14; Szőke/Buzás 1994, 124; Szőke/Búzás/Kocsis 1997, 126; syntéza v Hanuš 2016, 215, 216, 218). V novom paláci už vykurovanie zabezpečovali len kachlové pece a krby. Jediná funkčná a zároveň v tomto období postavená teplovzdušná pec je doložená v král'ovskom kúpeli (Buzás 1994, 101, 102; 2003; 2009; 2010a; Buzás/Laszlovszky 1995, 25; Buzás/Laszlovszky/Magyar 2003, 361; Héjj 1954, 45, 47; syntéza v Hanuš 2016, 219, 220). Prakticky v rovnakom období zaznamenal prvé známky zanechania technológie v Nemecku aj K. Bingenheimer $(1998,174)$. Na novopostavených hradoch nemeckých rytierov sa už od poslednej tretiny 14. stor. d’alšie zariadenia neobjavujú. Čo sa týka kachiel', nádobkovité sú doložené vo Vyšehrade už od začiatku anjouovskej fázy. Našli sa v aristokratických rezidenciách vykurovaných na prízemí, resp. prvom podlaží, hypokaustami. Kedže tu základy kachlových pecí neboli doložené, predpokladá sa, že mohli vykurovat' obytné priestory na poschodí. Od vlády L’udovíta I. sa v areály královského paláca objavujú prvé komorové zdobené kachle (Kocsis/Sabján 1998, 45). Ide pritom o rovnaké obdobie, kedy je doložené prvé vyrad’ovanie hypokaust. Nová reprezentačná funkcia zdobených komorových kachiel' sa tak javí ako bezprostredná príčina zanechania teplovzdušnej technológie.

K. Bingenheimer (1998, 173-194) hlbšie analyzoval fyzikálne správanie teplovzdušných a kachlových pecí a hlavnú príčinu zmeny nevidí v technických parametroch, ktoré nesvedčia jednoznačne len v prospech jedného spôsobu vykurovania. Rýchly príklon ku kachlovým peciam vidí skôr v záujme o nový estetický a reprezentačný charakter často bohato zdobených kachlíc, tvoriacich luxusnú súčasṫ interiéru. Podobne si v súvislosti s kultúrou bývania E. Roth-Kaufmann (1997, 481 n.) všíma, že s nadobudnutím tohto spoločenského aspektu sa kachlové pece presúvajú z pôvodne len obytných do reprezentatívnych miestností, ktoré predtým typicky vykurovali krby. Domnievame sa, že dôležitým faktorom je aj skutočnost’, že hypokaustá, ktoré tvorila tažká konštrukcia, vykurovali obvykle len miestnosti na prízemí, resp. prvom poschodí. ${ }^{51}$ Pre vykurovanie vyšších poschodí bolo potrebné vybudovat systém teplovzdušných kanálov, ktorých konštrukcia bola náročná. Tomu zodpovedá aj skutočnost', že sa s nimi stretávame len vel’mi výnimočne (Hanuš 2016, 57-59). Naproti tomu, kachlovými pecami bolo možné l’ahšie zabezpečit vykurovanie na poschodiach. Za technickú výhodu kachlí možno považovat’ aj kontinuálnu obsluhu na rozdiel od hypokaust IV. typu, ktoré mali dvojfázovú prevádzku. Okrem toho kachlová pec obsluhovaná z vedlajšej miestnosti vylúčila aj riziko znečistenia vzduchu spalinami, ktoré hrozilo v prípade nesprávnej obsluhy teplovzdušnej pece.

Z uvedeného vyplýva, že nahrádzanie hypokaust kachlovými pecami v uhorskom král'ovskom prostredí začína už po polovici 14. stor. Tento trend je však postupný. Dokladajú to tri teplovzdušné pece v západnom krídle Budinského hradu (Feld 2006, 103; Gerevich 1966, 103; Holl 1997, 94; Magyar 1991, 215, 216; 1997, 120; Voit/Holl 1956, 73-82; Zolnay 1976, 218-221; 1977a, 74 nn.), ohl'adom ktorých výstavby sa vedie polemika. Datujú sa bud' do neskorej vlády L’udovíta I., čiže do 60. až 80. rokov 14. stor., alebo až do rannej vlády Žigmunda na konci storočia. V uhorskom panovníckom prostredí sa s výstavbou hypokaust stretávame naposledy na královskom hrade Tata, postavenom medzi rokmi 1397 až 1409 (Buzás 2010b, 105).

V uhorskom šlachtickom prostredí evidujeme výstavbu teplovzdušnej pece naposledy takmer v rovnakom období, medzi rokmi 1388 až 1414. Ide o pec na hrade Beckov (2.1), ktorý bol vtedy hlavným sídlom Stibora zo Stiboríc, „pravej ruky“ Žigmunda Luxemburského (Dvořáková 2003). Eventuálne o čosi mladšia môže byt’ problematická druhá pec zo západného paláca $\mathrm{v}$ Beckove (2.2) datovaná do prvej tretiny 15. stor.

Exempláre $\mathrm{z}$ meštianskeho prostredia vieme datovat' len rámcovo, reprezentuje ich pec $z$ Levoče (7.1), ktorej výstavbu možno pripustit ešte v prvej polovici 15. stor. Situáciu by zásadne posunulo potencionálne hypokaustum z Prešovskej radnice (11.1), postavené podla písomných prameňov v roku 1540. Treba dodat', že slúžilo na vykurovanie väzenia, čo predstavuje sociálnu perifériu.

V prostredí Uhorskej cirkvi, máme archeologicky doložený celkovo najmladší exemplár z kláštora v Letanovciach (6.2). Konzervatívne prostredie

\footnotetext{
${ }^{51}$ Poznáme len jeden exemplár hypokausta postaveného na poschodí - v radnici v Göttingene (Barthel 1964, obr. 3).
} 
kartuziánskeho kláštora sa javí ako pravdepodobné miesto pre uplatnenie $\mathrm{v}$ tejto dobe už archaickej technológie. Treba však dodat', že kachlové pece sa aj tu paralelne použivali na vykurovanie jednotlivých mniśskych ciel najneskôr od prelomu 15. a 16. stor. (Slivka 1988, 430, 433).

Od počiatku 15. stor. hypokaustá začali rýchlo nahrádzat’ kachlové pece. Na Slovensku tento proces ilustruje napr. situácia $\mathrm{v}$ hronskobeňadickom kláštore (3.1), ktorého refektár je v polovici 15. stor. vybavený kachlovou pecou a staršie hypokaustum v dôsledku stavebných úprav kláštora stráca funkčnost'. Analogická situácia je aj v Košiciach-Krásnej (4.2), kde teplovzdušnú pec nahrádzajú kachle osadené na rovnakom mieste $\mathrm{v}$ refektári.

Dynamiku vyradovania teplovzdušných pecí si môžeme všimnút aj z kvantitatívneho hladiska. Pravdepodobne už v priebehu 15. stor. zaniká takmer polovica zariadení a v 16. stor. zvyšná čast'. $\mathrm{V}$ prípade niektorých exemplárov však ide o posledný možný termín a je pravdepodobné, že k vyradeniu mohlo dôjst' už skôr. Najneskôr v 17. a 18. stor. zanikajú posledné dve hypokaustá (2.1, 2 Beckov). Taktiež tu však ide o najneskorší možných termín zániku, ktorý súvisí s finálnou deštrukciou vykurovaných stavieb.

V severnejších oblastiach strednej Európy a Pobaltí prežívala teplovzdušná technológia dlhšie. Na území Brandenburska zachytávame posledné novopostavené zariadenia $\mathrm{v} 70$. rokoch 16 . stor. vo františkánskom kláštore v Jüteborgu (Biermann/ Frey/Meyer 2013, 305). Ďalej na sever v dolnosaskom Lüneburgu, kláštoroch Lüne a Ebstorf, sú doklady používania ako aj výstavby hypokaust až do neskorého 17. stor. (Ring 2001, 29 n.). Podobne v Meklenburskom Stralsunde, na pobreží Baltského mora, mala byt posledná pec $\mathrm{v}$ prevádzke $\mathrm{v}$ prístavnej taverne do 17. stor. (Hoffmann/Kulessa/Möller 2008, 51). Technológia sa oproti juhovýchodnej Európe udržala dlhšie aj v Pol’sku. Posledné zariadenia pochádzajúce zo strednej časti Pol'ska, z kláštorov v Trzymeszne a Oporowe, fungovali rovnako až do druhej polovice 17. stor. (Bis 2003, 28). Na severovýchodnej periférii rozšírenia hypokaust, na historickom území Livónie, boli zariadenia vytlačené zo svojho pôvodného prostredia glazovanými kachlovými pecami už v 16. stor. Ich používanie tu ale kontinuálne pokračovalo $\mathrm{v}$ novom sociálnom a architektonickom kontexte, t. j. vo väčších rolníckych domoch majúcich aj funkciu stodoly, kde sa používali až do 20. stor. (Tvauri 2009, 75, 77).

Technológia sa v novoveku okrajovo uplatňovala aj v našom regióne, takže vedomost’ o nej sa nikdy celkom nestratila. Prežívala aj v nasledujúcich storočiach a vyvíjala sa do nových konštrukčných foriem (napr. zámok Velké Meziř́ičí; Konečný 1983, 462 n., obr. 17; plán zariadenia s opisom funkcie Böckler 1666, 13, 14, obr. H; Ebel 2003, 243, obr. 2: e), až kým v 19. stor. zaznamenala na istý čas renesanciu (Hanzlíková 2003, 289-292; Skružný 2003, 13). Pre hlbšie pochopenie vývoja fenoménu v novoveku bude potrebný další, najmä stavebno-historický a archívny výskum.

Pre obdobie stredoveku môže d’alší progres $\mathrm{v}$ bádaní priniest̉ okrem nových terénnych prác aj revízia starších výskumov z hradného a mestského prostredia. Zamerat' sa treba na prízemie a suterén obytných palácov a bohatých meštianskych domov na námestiach, so stavebnou aktivitou najmä v 14. stor. Doklady teplovzdušnej technológie pritom môžu indikovat už len zvyšky komínov, či dymovodov a fragmenty podlahových platní.

\section{LITERATÚRA}

Atzbach 2014 - R. Atzbach: The 'Stube' and its Heating. Archaeological Evidence for a Smoke-Free Living Room between Alps and North Sea. In: M. S. Kristiansen/ K. Giles (eds.): Dwellings, Identities and Homes. European Housing Culture from the Viking Age to the Renaissance. Højbjerg 2014, 195-209.

Barthel 1964 - H. J. Barthel: Eine Steinofen-Luftheizung im Deutschordenshof von Altmühlhausen. Alt-Thüringen 7, 1964, 326-339.

Beljak Pažinová 2017 - N. Beljak Pažinová: Vrcholnostredoveký hrad Pet’uša. Archaeologia historica 42, 2017, 453-467. DOI: https://doi.org/10.5817/AH2017-2-3

Beljak Pažinová/Ragač 2018 - N. Beljak Pažinová/R. Ragač: Hrad Pełuša - šlachtické sídlo alebo mýtna stanica? Konfrontácia archeologických a historických prameňov. Archaeologia historica 43, 2018, 187-201. DOI: https://doi.org/10.5817/AH2018-1-10

Biermann/Frey/Meyer 2013 - F. Biermann/K. Frey/C. Meyer: Erste Einsichten zur Baugestalt des uckermärkischen
Zisterzienserinnenklosters Seehausen. In: C. Theune/ G. Scharrer-Liška/E. H. Huber/T. Kühtreiber (Hrsg.): Stadt - Land - Burg. Festschrift für Sabine FelgenhauerSchmiedt zum 70. Geburtstag. Internationale Archäologie. Studia honoraria 34. Leidorf 2013, 295-308.

Bingenheimer 1998 - K. Bingenheimer: Die Luftheizung des Mittelalters. Zur Typologie und Entwicklung eines technikgeschichtlichen Phänomens. Antiquitates. Archäologische Forschungsergebnisse 17. Hamburg 1998.

Bis 2003 - W. Bis: Ze studiów nad piecami typu hypocaustum z terenu ziem Polski. Architectus 1-2 (13-14), 2003, 3-28.

Boockmann 1994 - H. Boockmann: Die Stadt im späten Mittelalter. München 1994.

Böckler 1666 - G. A. Böckler: Furnologia oder Haushältliche Oefen-Kunst. Frankfurt 1666.

Buśko 1995 - C. Buśko: Średniowieczne piece typu hypocaustum na Śląsku. Archeologia Historica Polona 1, 149-183.

Buzás 1990 - G. Buzás: Lapidarium Hungaricum 2. Magyarország épitészeti töredékeinek gyüjteménye. Pest megye I. 
Visegrád, Királyi palota 1. A kápolna és az északkeleti palota. Budapest 1990.

Buzás 1992 - G. Buzás: A visegrádi királyi palota déli épülettömbjének feltárása. Múemlékvédelmi Szemle 1992/2, 1992, 32-43.

Buzás 1994 - G. Buzás (szerk.): A visegrádi királyi palota kápolnája és északkeleti épülete. Visegrád régészeti monográfiái 1. Visegrád 1994.

Buzás 1995 - G. Buzás: The remains of the royal palace of Visegrád from the Angevin period. In: Medieval Visegrád. Budapest 1995, 9-19.

Buzás 2003 - G. Buzás: A visegrádi királyi palota fürdője. Budapest Régiségei 37, 2003, 151-166.

Buzás 2009 - G. Buzás: Középkori fürdők. Müemlékvédelem 53, 2009, 285-289.

Buzás 2010a-G. Buzás: A visegrádi királyi palota története. In: G. Buzás/K. Orosz (szerk.): A királyi palota. Visegrád 2010, 11-107.

Buzás 2010b - G. Buzás: A tatai vár 1510-ben. In: J. László (szerk.): A diplomácia válaszútján. 500 éve volt Tatán országgyúlés. Annales Tataienses VI. Tata 2010, 93-113.

Buzás 2012 - G. Buzás: A kisnánai vár története. Archaeologia - Altum Castrum Online Magazin 2012, 2-54.

Buzás 2013 - G. Buzás: A visegrádi királyi palota. Kiállitási vezetô. Archeológia könyvek I. Visegrád 2013.

Buzás/Bodó/Deák 2003 - G. Buzás/B. Bodó/Z. Deák: A visegrádi királyi palota Anjou-kori kőtára. Visegrád Régeszeti Monográfiái 5. Visegrád 2003.

Buzás/Laszlovszky 1995 - G. Buzás/J. Laszlovszky: Life at Visegrád palace under the reign of King Matthias. In: J. Laszlovszky (ed.): Medieval Visegrád. Royal castle, palace, town and Franciscan friary 4. Budapest 1995, 19-25.

Buzás/Laszlovszky/Magyar 2003-G. Buzás/J. Laszlovszky/K. Magyar: Középkori királyi központok. In: Z. Visy (főszerk.): Magyar régészet az ezredfordulón. Budapest 2003, 348-364.

Buzás/Szőke 1992 - G. Buzás/M. Szőke: A visegrádi vár es kiráryi palota a 14-15. században. Die Burg und der königliche Palast von Visegrád im 14.-15. Jahrhundert. Castrum Bene 2, 1992, 132-156.

Buzás/Szőke 2000 - G. Buzás/M. Szőke: Houses in the fourteenth century town of Visegrád. In: M. F. Font/M. G. Sándor (Hrsg.): Mittelalterliche Häuser und Straßen in Mitteleuropa. Varia archaeologica Hungarica 9. Budapest 2000, 119-128.

Čurný/Gregor/Hložek 2018 - M. Čurný/M. Gregor/M. Hložek: Kláštor benediktínov v Ludaniciach: výsledky štúdia tehál. In: M. Kvasnicová/M. Šeregi (zost.): Architektúra kláštorov a reholných domov na Slovensku. Dejiny a pamiatková ochrana. Bratislava 2018, 394-412.

Čurný/Hložek 2007 - M. Čurný/M. Hložek: Výpovedná schopnost' tehál z benediktínskeho kláštora sv. Kozmu a Damiána v Ludaniciach, okr. Topol'čany. Archeologia technica 19, 2007, 68-82.

Domenová 2010 - M. Domenová: Prešov. In: M. Štefánik/ J. Lukačka a kol.: Lexikon stredovekých miest na Slovensku. Bratislava 2010, 331-351.

Dvořák et al. 1998 - J. Dvořák/L. Horáčková/L. Vargová/ R. Zatloukal: Výzkumy v dominikánském a minoritském klášteře v Jihlavě. Pravěk. Nová řada 8, 1998, 303-319.

Dvořáková 2003 - D. Dvořáková: Rytier a jeho král. Stibor zo Stiboríc a Žigmund Luxemburský. Sonda do života stredovekého uhorského šlachtica s osobitným zretel'om na územie Slovenska. Budmerice 2003.

Ebel 2003 - M. Ebel: Furnologie aneb hledání cesty k úspornému topení do poloviny 19. století v soudobých vzor- nících. In: Svorník 1. Sborník přispěvků z I. konference stavebně historického průzkumu 4.-6.6. 2002 v Zahrádkách u České Lípy. Vývoj a funkce topeništ'. Praha 2003, 241-254.

Feld 2006 - I. Feld: Zur Frage der Beheizung auf mittelalterlichen Burgen (Schwerpunkt Ungarn). In: J. Zeune (Hrsg.): Alltag auf Burgen im Mittelalter. Braubach 2006, 100-107.

Gajdošová/Paulusová 1997 - I. Gajdošová/S. Paulusová: Kláštor na Vel'kej Skalke, výskum a obnova. Pamiatky a múzeá 3, 1997, 41-44.

Gerevich 1966 - L. Gerevich: A budai vár feltárása. Budapest 1966.

Giber 2008 - M. Giber: Az egri várbeli késő középkori püspöki palota. Castrum Bene 7, 2008, 49-88.

Gojdič/Paulusová 2010 - I. Gojdič/S. Paulusová: Fragmenty stredovekých dominikánskych kláštorov v Banskej Štiavnici a Košiciach. Monumentorum tutela 22, 2010, 295-306.

Gróf/Kováts 2014 - P. Gróf/I. Kováts: Árpád-kori temetőrészlet és 14. századi hypocaustum Visegrád belterületéről. Communicationes Archaeologicae Hungariae 2014, 185-198.

H. Gyürky 1981 - K. H. Gyürky: Das mittelalterliche Dominikanerklöster in Buda. Fontes Archaeologici Hungariae. Budapest 1981.

Habovštiak/Holčík 1975a - A. Habovštiak/Š. Holčík: Stavebno-historický vývoj národnej kultúrnej pamiatky v Hronskom Beňadiku. Vlastivedný časopis 24/2, 1975, 70-77.

Habovštiak/Holčík 1975b - A. Habovštiak/Š. Holčík: Ďalšie dva roky archeologického výskumu v areáli NKP Hronský Beňadik. Pamiatky a príroda 3, 1975, 14-17.

Habovštiak/Holčík 1994 - A. Habovštiak/Š. Holčík: Príspevok archeologického výskumu k poznaniu stavebného vývoja kláštora v Hronskom Beňadiku. In: J. Šimončič (zost.): Dejiny a kultúra reholných komunít na Slovensku. Príspevky na II. sympóziu o cirkevných dejinách Slovenska na Trnavskej univerzite 15.-16. 10. 1993. Trnava 1994, 137-149.

Hanuliak 1996 - M. Hanuliak: Vztah príslušníkov dominikánskej rehole k obyvatel'om Banskej Štiavnice. Archaeologia historica 21, 1996, 219-231.

Hanuliak/Hoššo/Hunka 1996 - M. Hanuliak/J. Hoššo/J. Hunka: Najvýznamnejšie poznatky z výskumu banskoštiavnického dominikánskeho kláštora. K schopnostiam výpovede tradičných datovacích prostriedkov. Slovenská archeológia 44, 1996, 307-326.

Hanuliak/Ragač 2000 - V. Hanuliak/R. Ragač: Príspevok k problematike existencie kláštorného hospica a Kostola sv. Ducha v Slovenskej Lupči. Archaeologia historica 25, 2000, 233-244.

Hanuš 2016 - M. Hanuš: Stredoveké teplovzdušné vykurovania v strednej Európe. Dizertačná práca. Univerzita Komenského v Bratislave. Bratislava 2016. Dostupné na: https:/opac.crzp.sk/?fn=detailBiblioForm\&si$\mathrm{d}=67 \mathrm{~B} 569$ DE93B0833F1D4261AEA79E\&seo=CRZP-detail-kniha

Hanuš 2018 - M. Hanuš: Kláštor benediktínov v Ludaniciach: nález teplovzdušnej vykurovacej pece. In: M. Kvasnicová/M. Šeregi (zost.): Architektúra kláštorov a reholných domov na Slovensku. Dejiny a pamiatková ochrana. Bratislava 2018, 388-393.

Hanuš/Kušnirák 2014 - M. Hanuš/D. Kušnirák: Podoba benediktínskeho kláštora sv. Kozmu a Damiána v Ludaniciach na základe archeologického a geofyzikálneho výskumu. Študijné zvesti Aú SAV 56, 2014, 155-168.

Hanzlíková 2003 -J. Hanzlíková: Příklady způsobu vytápění zámeckých objektů v 19. století. In: Svorník 1. Sborník př́spěvků z I. konference stavebně historického průzkumu 
4.-6. 6. 2002 v Zahrádkách u České Lípy. Vývoj a funkce topeništ'. Praha 2003, 289-300.

Hauserová 2003 - M. Hauserová: Teplovzdušné vytápění ve středověku. In: Svorník 1. Sborník příspěvkĩ z I. konference stavebně historického prüzkumu 4.-6. 6. 2002 v Zahrádkách u České Lípy. Vývoj a funkce topeništ'. Praha 2003, 49-74.

Hauserová 2015 - M. Hauserová: Špičky tepelné techniky středověku. In: M. Dulla a kol.: Kapitoly z historie bydlení. Praha 2015, 63-76.

Haviar 2013 - T. Haviar: Benediktíni v Hronskom Beňadiku - otázniky histórie. In: Templársky rád v Európe v kontexte historického vývoja Žilinského kraja. Žilina 2013, 113-120.

Hawel 1993 - P. Hawel: Das Mönchtum im Abendland. Freiburg - Basel - Wien 1993.

Hefner 2010 - Z. Hefner: Teplovzdušné topení na hradě Novém Šumburku. Hláska. Zpravodaj Klubu Augusta Sedláčka 21/2, 2010, 27, 28.

Héjj 1954 - M. Héjj: Visegrád történeti emlékei. Budapest 1954.

Hoffmann/Kulessa/Möller 2008 - C. Hoffmann/B. Kulessa/ G. Möller: Hus un Hoff. Wohnbauten im mittelalterlichen Stralsund. Schriftenreihe Stralsunder Denkmale. Heft 3. Stralsund 2008.

Holčík 1978 - Š. Holčík: Stredoveké kachliarstvo. Bratislava 1978.

Holl 1997 - I. Holl: A budai palota középkori építéstörténetének kérdései. Budapest Régiségei 31, 1997, 79-99.

Hoššo 1999 - J. Hoššo: K otázke stavania kachlových pecí v dedinských domoch na území Slovenska v stredoveku. Archaeologia historica 24, 1999, 401-408.

Hunčaga 2008 - G. P. Hunčaga: Historické štúdie k dejinám dominikánov. Bratislava 2008.

Hunčaga 2013 - G. P. Hunčaga: Dominikáni na ceste k intelektuálnym elitám vrcholného stredoveku. Kraków - Bratislava 2013.

Husovská/Urbanová/Kosová 2016 - L. Husovská/N. Urbanová/B. Kosová: Č. UZPF 2929/1-2. Pamätný meštiansky dom - Hainov dom, sídlo evanjelického lýcea. Námestie Majstra Pavla č. 40. In: N. Urbanová/B. Kosová/L. Szerdová-Velasová (zost.): Národné kultúrne pamiatky na Slovensku. Levoča. Bratislava 2016, 342-346.

Jakubčin 2018 - P. Jakubčin: Kláštor cistercitov v Spišskom Štiavniku - vybrané aspekty z histórie. In: M. Kvasnicová/M. Šeregi (zost.): Architektúra kláštorov a reholných domov na Slovensku. Bratislava 2018, 263-270.

Jankovič 1965 - V. Jankovič: Dominikánsky kostol a kláštor v Banskej Štiavnici a jeho najbližšie okolie. Vlastivedný časopis 16, 1965 127-132.

Jankovič 1975 - V. Jankovič: Z minulosti Hronského Beňadika. Pamiatky a príroda 3, 1975, 5-7.

Janovská 2012 - M. Janovská: Spišský hrad - výsledky nových výskumov (so zameraním na stavebný vývoj v stredoveku). Monumentorum tutela 24, 2012, 279-298.

Javorský 1990-F. Javorský: Záchranné výskumy a prieskumy v mestskej pamiatkovej rezervácii Levoča. AVANS 1988, $1990,81-84$

Judák 2002 - V. Judák: Nitriansky svätci. In: R. Marsina (zost.): Nitra v slovenských dejinách. Martin 2002, 13-31.

Keglevich 2012 - K. Keglevich: A Garamszentbenedeki apátság története az Árpád-es az Anjou-korban (1075-1403). Szeged 2012.

Klápště/Muk/Bubeník 2010 - J. Klápště/J. Muk/J. Bubeník: Klášter minoritů v Mostě. Archeologické rozhledy 62, 2010, 429-468.

Kluttig-Altmann 2015 - R. Kluttig-Altmann: Zieglerdeckel aus Wittenberg im überregionalen Kontext. Die Suche nach der Funktion einer besonderen Fundgruppe. Forschungsberichte des Landesmuseums für Vorgeschichte Halle 7, 2015, 41-92.

Kocsis/Sabján 1998 - E. Kocsis/T. Sabján: A visegrádi királyi palota kályhái és kályhacsempe leletei. Visegrád régészeti monográfiái 3. Visegrád 1998.

Kodoňová/Tóthová 1995 - M. Kodoňová/Š. Tóthová: Hrad Beckov. Výsledky výskumu národnej kultúrnej pamiatky. Bratislava 1995.

Konečný 1983 - L. J. Konečný: Odkryv teplovzdušného zařízení na hradě Vranově n. Dyjí a jeho postavení v evropském vývoji. Archaeologia historica 8, 1983, 449-470.

Kopták 2014 - T. Kopták: K stavebným dejinám cistercitského opátstva v Spišskom Štiavniku. Historický zborník 24/1-2, 2014, 31-59.

Koszta 2009 - L. Koszta: Benediktínsky kláštor z 11. storočia na Spiši? Historický časopis 57, 2009, 339-356.

Kwiatkowska-Kopka 2011 - B. Kwiatkowska-Kopka: Badania archeologiczne w obrębie nieistniejącego skrzydła północnego w dawnym klasztorze oo. Cystersów w Koprzywnicy. Cistercium Mater Nostra 5, 2011, 55-75.

Luštíková 2008 - L. Luštíková: Hospodárske objekty benediktínskeho kláštora v Košiciach-Krásnej. Archaeologia historica 33, 2008, 331-341.

Magyar 1991 - K. Magyar: Der Königspalast in Buda. In: G. Biegel (Hrsg.): Budapest im Mittelalter. Braunschweig 1991, 201-235.

Magyar 1997 - K. Magyar: A középkori budai királyi palota fó építési korszakainak alaprajzi rekonstrukciója I. Budapest Régiségei 31, 1997, 101-120.

Marsina 1997 - R. Marsina: Benediktínske opátstvo Skalka (Skala). In: Marsina a kol. 1997, 94-101.

Marsina a kol. 1997 - R. Marsina a kol.: Skalka pri Trenčíne. Miesto legiend a pútí. Zborník z vlastivedného seminára 23. mája 1996. Trenčín 1997.

Mencl 1966 - V. Mencl: Kláštor sv. Beňadika nad Hronom. Vlastivedný časopis 15, 1966, 147-160.

Meyer 1989 - D. Meyer: Warmluftheizungen des Mittelalters. Befunde aus Lübeck in europäischen Vergleich. Lübecker Schriften zur Archäologie und Kunstgeschichte 16, 1989, 217-219.

Meyer 2001 -D. Meyer: Warmluftheizungen in Norddeutschland im 13. bis 16. Jahrhundert. In: M. Schneider (Hrsg.): Von der Feuerstelle zum Kachelofen - Heizanlagen und Ofenkeramik vom Mittelalter bis zur Neuzeit. Beitrage des 3. wissenschaftlichen Kolloquiums Stralsund 9.-11. Dezember 1999. Stralsunder Beiträge zur Archäologie, Geschichte, Kunst und Volkskunde in Vorpommern 3. Stralsund 2001, 2, 3.

Mészáros 2008 - O. Mészáros: Visegrád késő középkori város története és helyrajza. Dizertačná práca. Debreceni Egyetem. Debrecen 2008. Dostupné na: https://dea.lib. unideb.hu/dea/handle/2437/117153

Miklós 1997 - Z. Miklós: Falvak, várak, kolostorok a Dél-Börzsönyben. Váci Könyvek 8, 1997, 7-158.

Mosný/Selecká 2005 - P. Mosný/P. Selecká: Kláštor v Slovenskej Ĺupči. Archaeologia historica 30, 2005, 435-441.

Mosný/Selecká 2006 - P. Mosný/P. Selecká: Kláštorisko v Slovenskej L'upči - výskum hrobky. Archaeologia historica 31, 2006, 345-348.

Möller 2006 - G. Möller: Mittelalterliche Luftheizungen in Stralsund-neue Befunde. In:St. Brüggemann(Hrsg.): Keller in Mittelalter und Neuzeit. Beiträge zur Archäologie, Baugeschichte und Geschichte. Langenweissbach 2006, 45-58.

Nagy 2009 - Sz. Nagy: The medieval castle of Kisnána. Castrum 10, 2009, 37-42. 
Nagy 2011 - Sz. Nagy: Összefoglaló a kisnánai vár 2010. évi tavaszi-nyári ásatásairól. Castrum 14, 2011, 83-99.

Nádaská 2011 - K. Nádaská: Cirkevné dejiny Košíc v 13.-16. stor. s dôrazom na kult sv. Alžbety. Dizertačná práca. Univerzita Komenského v Bratislave. Bratislava 2011. Nepublikované. Dostupné na: https://opac.crzp.sk/?f$\mathrm{n}=$ docviewChild00040A4F

Nešporová 1992 - T. Nešporová: Regionálny prieskum na strednom Považí. AVANS 1991, 1992, 86.

Nipčová 2011 - D. Nipčová: Vel'ká Skalka v obraze archeologických prameňov a kláštorný život v stredoveku. In: I. Zmeták (zost.): Okno do histórie Skalky pri Trenčíne. Kultúrno-historická príloha katalógu 4. ročníka medzinárodného výtvarno-literárneho sympózia Ora et ars - Skalka 2011. Trenčín 2011, 18-25.

Oriško 2003 - Š. Oriško: Hronský Beňadik. Kláštorný kostol bývalého benediktínskeho opátstva. In: D. Buran a kol. (zost.): Gotika. Dejiny slovenského výtvarného umenia. Bratislava 2003, 632-634.

Oriško 2004 - Š. Oriško: K počiatkom stredovekého meštianskeho domu na Spiši (Jednopriestorový kamenný dom). Archaeologia historica 29, 2004, 267-281.

Oslanský 1999 - F. Oslanský: K vizitácii benediktínskych kláštorov na Slovensku začiatkom 16. storočia. Historický časopis 47, 1999, 18-32.

Pámer 1970 - N. Pámer: A kisnánai vár feltárása. In: Magyar Müemlékvédelem 1967-1968. Budapest 1970, 295-313.

Pámer 1998 - N. Pámer: Kisnána, várrom. Tájak Korok Múzeumok Kiskönyvtára 581. B. m. v., b. r. v. (Budapest 1998).

Plaček/Bóna 2007 - M. Plaček/M. Bóna: Encyklopédia slovenských hradov. Bratislava 2007.

Polla 1957 - B. Polla: Stredoveká pec na pečenie chleba. Študijné zvesti Aú SAV 2, 1957, 115-119.

Polla 1962 - B. Polla: Stredoveká zaniknutá osada na Spiši (Zalužany). Bratislava 1962.

Polla 1986 - B. Polla: Košice-Krásna. K stredovekým dejinám Krásnej nad Hornádom. Košice 1986.

Pomfyová 2000-2001 - B. Pomfyová: Súčasný obraz spišskej sakrálnej architektúry do konca 13. storočia. Studia archaeologica slovaca mediaevalia 3-4, 2000-2001, 295-315.

Pomfyová 2003 - B. Pomfyová: Spišský Štiavnik (okr. Poprad). Cisterciánsky kláštor Panny Márie, súbor architektonických fragmentov. In: D. Buran a kol. (zost.): Gotika. Dejiny slovenského výtvarného umenia. Bratislava 2003, 618, 619 .

Pomfyová 2015 - B. Pomfyová: Ranostredoveké kláštory na Slovensku: torzálna architektúra - torzálne poznatky - torzálne hypotéty. Archaeologia historica 40, 2015, 733-777.

Pomfyová 2018 - B. Pomfyová: Stredoveká architektúra žobravých reholí na Slovensku - stav výskumu a problémové okruhy. In: M. Kvasnicová/M. Šeregi (zost.): Architektúra kláštorov a reholných domov na Slovensku. Bratislava 2018, 47-137.

Puškárová 1975 - B. Puškárová: Pamiatkársky výskum v Hronskom Beňadiku. Pamiatky a príroda 3, 1975, 8-13.

Radová-Štiková 1981 - M. Radová-Štiková: Vytápění teplým vzduchem v období gotickém. Dejiny věd a techniky 14, 1981, 67-75.

Rábik 2010 - V. Rábik: Partizánska L'upča. In: M. Štefánik/ J. Lukačka a kol.: Lexikon stredovekých miest na Slovensku. Bratislava 2010, 314-322.

Reichertová/Radová 1981 - K. Reichertová/M. Radová: Podzemní výhřevná pec (kamna) v klášteře Sázavě, okr. Kutná Hora. Archeologické rozhledy 33, 1981, 398-410.
Ring 2001 - E. Ring: Herdstelle, Heißluftheizung, Kachelofen, Kamin. Wärmequellen in Lüneburger Häusern. In: M. Schneider (Hrsg.): Von der Feuerstelle zum Kachelofen. Heizanlagen und Ofenkeramik vom Mittelalter bis zur Neuzeit. Stralsunder Beiträge III. Stralsund 2001, 28-42.

Roth-Kaufmann 1997 - E. Roth-Kaufmann: Ofen und Wohnkultur. In: G. De Boe/F. Verhaeghe (eds.): Material Culture in Medieval Europe. Papers of the 'Medieval Europe Brugge 1997' Conference. Volume 7. I. A. P. Rapporten 7. Zellik 1997, 471-483.

Rusnák 2011 - R. Rusnák: Dve stredoveké parcely v Košiciach. Slovenská archeológia 59, 2011, 149-186.

Rusnák 2018 - R. Rusnák: Nálezy stavebnej keramiky z výskumu gotickej fázy dominikánskeho kláštora v Košiciach. Forum urbes medii aevi 9/1-2, 2018, 186-195.

Rusnák/Volovár 2013 - R. Rusnák/M. Volovár: Zaznamenal Alexander Canoval v 17. storočí dispozíciu dominikánskeho kláštora v Košiciach? Východoslovenský pravek 10, 2013, 171-187.

Skružný 2003 - L. Skružný: Funkce a vývoj otopných zařízení v období od paleolitu po novověk ( $Z$ historie otopných zařízení). In: Svorník 1. Sborník příspěvki̊ z I. konference stavebně historického průzkumu 4.-6. 6. 2002 v Zahrádkách u České Lípy. Vývoj a funkce topeništ'. Praha 2003, 7-42.

Slivka 1988 - M. Slivka: Doterajšie výsledky výskumu na Kláštorisku v Slovenskom raji. Archaelogia historica 13, 1988, 423-439.

Slivka 1991 - M. Slivka: Cisterciti na Slovensku. Archaelogia historica 16, 1991, 101-117.

Slivka 1993 - M. Slivka: Fundačný proces cistercitských kláštorov na Slovensku. Východoslovenský pravek 4, 1993, 191-195.

Slivka 2001-2002 - M. Slivka: Kristianizačný proces na Spiši. K počiatkom Spišskej Kapituly. Z minulosti Spiša 9-10. 2001-2002, 23-40.

Slivka 2003 - M. Slivka: Sídlisková a cirkevná štruktúra Spiša vo včasno a vrcholnostredovekom období. In: R. Gładkiewicz/M. Homza/M. Pułaski/M. Slivka (red.): Terra Scepusiensis. Stav bádania o dejinnách Spiša. LevočaWrocław 2003, 419-448.

Slivka/Chalupecký 1995 - M. Slivka/I. Chalupecký: Kláštorisko - Skala útočišta - Letanovce. Vreckový sprievodca pamiatkami Spiša 2. Spišská Nová Ves 1995.

Slivka/Vallašek 1991 - M. Slivka/A. Vallašek: Hrady a hrádky na východnom Slovensku. Košice 1991.

Soukupová 2015 - H. Soukupová: Svatá Anežka Česká. Život a legenda. Praha 2015.

Stejskal 2009 - M. Stejskal: Súčast’ teplovzdušnej pece. In: M. Novotná (ed.): Terra Scepusiensis - Terra Christiana 1209-2009. Spišský hrad, Spišská kapitula. Dve centrá $v$ dejinách Spiša. Levoča 2009, 132, 133.

Styk/Beljak Pažinová 2020 - M. Styk/N. Beljak Pažinová: 3D Reconstruction as a Form of Interpretation: Example of Excavation of the Medieval Petuša Castle (Central Slovakia). Interdisciplinaria Archaeologica 11, 2020, 73-87. DOI: https://doi.org/10.24916/iansa.2020.1.6

Suchý 1974 - M. Suchý: Významné pramene k problematike stavebného vývinu východoslovenských miest zo začiatku 17. storočia. Nové obzory 16, 1974, 39-83.

Szakál 1984 - E. Szakál: A budavári gótikus szoborlelet sérüléseinek és eltemetésének jelképrendszere. Budapest Régiségei 26, 1984, 271-321.

Szeghyová 1998 - B. Szeghyová: Príspevok k dejinám mestského súdnictva (Mestská súdna kniha Prešova 1555-1560). Slovenská archivistika 33, 1998, 60-76. 
Szóke/Buzás 1994-M. Szőke/G. Buzás: 168/3. Visegrád - királyi palota. In: K. Wollák (szerk.): Az 1992 év régészeti kutatásai. Régészeti Füzetek I, 46, 1994. Budapest 1994, 122-124.

Szőke/Buzás 2001 - M. Szőke/G. Buzás: Visegrád - Königlicher palast. In: K. Mesterházy (szerk): Archaeological Reports 1997. Régészeti Füzetek I, 51, 1998. Budapest 2001, 197.

Szőke/Búzás/Kocsis 1997 - M. Szőke/G. Búzás/E. Kocsis: 169/3. Visegrád-királyi palota. In: K. Wollák (szerk.): Az 1995 év régészeti kutatásai. Régészeti Füzetek I, 49, 1997. Budapest 1997, 125-127.

Tóth Feuerné 1963 - R. Tóth Feuerné: Középkori hypokaustum a Margitszigeten. Budapest Régiségei 20, 1963, 427-448.

Tvauri 2009 - A. Tvauri: Late medieval hypocausts with heat storage in Estonia. Baltic Journal of Art History 1/ autumn issue, 2009, 49-78.

Urbanová 1986 - N. Urbanová: Prešov. Pamiatková rezervácia. Bratislava 1986.

Urbanová 2003a - N. Urbanová: Základy stredovekých miest - urbanistická štruktúra. In: D. Buran a kol. (zost.): Gotika. Dejiny slovenského výtvarného umenia. Bratislava 2003, 71-85.

Urbanová $2003 b$ - N. Urbanová: Prešov, Mestská vináreň a zbrojnica/Hlavná ulica č. 73 (vináreň, neskôr radnica), Jarkova ulica. In: D. Buran a kol. (zost.): Gotika. Dejiny slovenského výtvarného umenia. Bratislava 2003, 613, 614.

Vallašek 1999 - A. Vallašek: Zaniknutý kláštor svätého Martina nad Spišskou Kapitulou. Pamiatky a múzeá 2, 1999, 61-65.

Várady 1783 - P. Várady: Plan Deren samtlichen Gebauden in dem zu den Fundum Studiorum gehörigen Praedio Szkálka. 1783. S 12 Div. V No. 0006.

Végh 1983 - A. Végh: Buda város középkori helyrajza 1. Monumenta Historica Budapestinensia 15. kötet. Budapest 1983.
Voit/Holl 1956 - P. Voit/I. Holl: Hunyadi Mátyás budavári majolikagyártó mühelye. Budapest

Régiségei 17, 1956, 73-150.

Volovár 2017 - M. Volovár: Kostol košických dominikánov a jeho kameňosochársky program. Průzkumy památek 24, 2017, 187-221.

Wick 1932 - V. Wick: Dáta k dejinám košických dominikánov. Košice 1932.

Wühr 1985 - C. B. Wühr: Archäologische Ausgrabungen im Kreuzgang. In: H. Fasching (Hrsg.): Dom und Stift St. Pölten und ihre Kunstschätze. St. Pölten - Wien 1985, 71-76.

Zatloukal 1996 - R. Zatloukal: Nález dvou středověkých pecí typu hypocaustum $\mathrm{v}$ minoritském klášteře v Jihlavě. Vlastivědný sborník Vysočiny 10, 1996, 11-34.

Zmeták 2011 - I. Zmeták (zost.): Okno do histórie Skalky pri Trenčine. Kultúrno-historická príloha katalógu 4. ročníka medzinárodného výtvarno-literárneho sympózia Ora et ars - Skalka 2011. Trenčín 2011.

Zolnay 1976 - L. Zolnay: Der gotische Skulpturenfund von 1974 in der Burg von Buda. Acta Historiae Artium Academiae Scientiarum Hungaricae 22, 1976, 173-331.

Zolnay 1977a - L. Zolnay: Az 1967-75. évi budavári ásatásokról s az itt talált gótikus szoborcsoportról. Budapest Régiségei 24/3, 1977, 3-164.

Zolnay 1977b - L. Zolnay: Az 1967-75. évi budavári ásatásokról s az itt talált gótikus szoborcsoportról. Budapest Régiségei 24/4, 1977, 3-239.

Zolnay/Szakál 1976 - L. Zolnay/E. Szakál: Der gotische Skulpturenfund in der Burg von Buda. Budapest 1976.

Žažová 2018 - H. Žažová: Kláštor premonštrátov v Lelese: archívne pramene k stavebným dejinám. In: M. Kvasnicová/M. Šeregi (zost.): Architektúra kláštorov a reholných domov na Slovensku. Bratislava 2018, 242-262.

Žuffová 2009 - J. Žuffová: Doplňujúce poznatky k typu primárneho murovaného meštianskeho domu Trnavy. Pamiatky Trnavy a Trnavského kraja 12, 2009, 47-66.

\section{NEPUBLIKOVANÉ PRAMENE}

Habovštiak/Holčík 1972 - A. Habovštiak/Š. Holčík: Nálezová správa $z$ archeologického výskumu v Hronskom Beñadiku NKP, v r. 1972. Bratislava 1972. Výskumná správa T866. Pamiatkový úrad SR.

Habovštiak/Holčík 1974 - A. Habovštiak/Š. Holčík: Nálezová správa z výskumu NKP (Charitný domov) v Hronskom Beňadiku, okr. Žiar nad Hronom, 1973. Bratislava 1974. Výskumná správa 16/75. Archeologické múzeum SNM.

Habovštiak/Holčík 1975c - A. Habovštiak/Š. Holčík: Nálezová správa z archeologického výskumu v Hronskom Beňadiku NKP, v r. 1974. Bratislava 1975. Výskumná správa 17/75. Archeologické múzeum SNM.

Habovštiak/Holčík 1976 - A. Habovštiak/Š. Holčík: Nálezová správa $z$ archeologického výskumu v Hronskom Beňadiku NKP v roku 1975. Bratislava 1976. Výskumná správa 9/76. Archeologické múzeum SNM

Hanuliak 1994 - M. Hanuliak: Vrcholnostredoveký dominikánsky kláštor v Banskej Štiavnici, etapa III. Bratislava 1994. Výskumná správa T5212/b. Pamiatkový úrad SR.

Haviarová/Haviar 2015 - M. Haviarová/T. Haviar: Kláštor na Vel'kej Skale - čast' konvent. Čiastkový architektonicko-historický výskum. Zhrňujúca a aktualizačná dokumentácia čiastkových výskumov, bez juhozápadného múra v úrovni III. NP s vežou. Výskumná správa 2015. KPÚ Trenčín.

Horňák/Krištofová 2012 - M. Horňák/V. Krištofová: Obnova kláštora na Vel'kej Skalke, SO 106 - obnova schodiska do rajskej záhrady. Výskumná dokumentácia z archeologického výskumu. Vrútky 2012. KPÚ Trenčín.

Hrašková/Hanuš/Miňo 2006-E. Hrašková/M. Hanuš/M. Miňo: Banská Štiavnica - dominikánsky kláštor. Výskumná dokumentácia z archeologického výskumu v roku 2006. Bratislava 2006. Výskumná správa. KPÚ Banská Bystrica (materiál je súčastou spisovej agendy, súkromný archív autora).

Jančušková 1971 - M. Jančušková: Stavebno-historický výskum hradu Beckova. Skúmaný objekt: Hradná kaplnka so sakristiou a dvojtraktový gotický palác. Bratislava 1971. Výskumná správa T814b. Pamiatkový úrad SR.

Jančušková 1972 - M. Jančušková: Stavebno-historický výskum hradu Beckov. Skúmaný objekt: Horné nádvorie, priečny palác, renesančný trakt a hospodárska čast' horného hradu. Bratislava 1972. Výskumná správa T814. Pamiatkový úrad SR.

Kopták 2012 - T. Kopták: Cisterciti na Slovensku. Dizertačná práca. Filozofická fakulta Trnavskej univerzity v Trnave. Katedra dejín a teórie umenia. Trnava 2012. 
Dostupné na: https://www.academia.edu/21504310/ Cisterciti_na_Slovensku

Kürthy/Glocková 2012 - L. Kürthy/B. Glocková: Architektonicko-historický a umelecko-historický pamiatkový výskum budov premonštrátskeho kláštora v Lelesi (č. ÚZPF 27/1), október 2011-január 2012. Výskumná správa 2012. KPÚ Košice.

Malec 2020 - J. Malec: NKP Hrad Beckov - obnova tzv. prachárne a pece. Trenčín 2020. Výskumná správa 27/2020. KPÚ Trenčín.

Pachanská/Hlavačková 1993 - K. Pachanská/M. Hlavačková: Skalka-kláštor. Archívny výskum 1993. Archív PÚ SR $(\mathrm{T}-2819)$.

Pellová 2007 -D. Pellová: Archívny výskum. In: Petranská 2007.

Petranská 2007 - D. Petranská: Architektonicko-historický pamiatkový výskum Caraffovej väznice v Prešove. Prešov 2007. Výskumná správa V194 (7/159). KPÚ Prešov.

Polla 1975 - B. Polla: Nálezová správa z historicko-archeologického výskumu Krásna nad Hornádom, poloha Breh, rok 1975. Bratislava 1975. Výskumná správa 24/77. Archeologické múzeum SNM.

Polla 1977 - B. Polla: Nálezová správa z historicko-archeologického výskumu Košice-Krásna, poloha Breh, 1. júl31. august 1977. Bratislava 1977. Výskumná správa 2/79. Archeologické múzeum SNM.

Polla 1978 - B. Polla: Nálezová správa z historicko-archeologického výskumu Košice-Krásna, 1. júl 1978-31. august 1978. Bratislava 1978. Výskumná správa 2/86. Archeologické múzeum SNM

Ragač 2006 - R. Ragač: Banská Štiavnica a dominikáni v stredoveku. In: Hrašková/Hanuš/Miňo 2006.

Rukopis prijatý 8. 3. 2021

Abstract translated by author

Zusammenfassung übersetzt von Verfasser
Rusnák 2009 - R. Rusnák: Košice v stredoveku. Na podklade archeologických výskumov. Dizertačná práca. Archeologický ústav SAV Nitra. Košice 2009.

Tóthová 1978 -Š. Tóthová: Správa o systematickom archeologickom výskume Beckov-horný hrad (okr. Trenčin). Bratislava 1978. Výskumná správa T1162/I. Pamiatkový úrad SR.

Vallašek 1973 - A. Vallašek: Predbežná správa o archeologickom výskume areálu Spišského hradu v roku 1973. Bratislava 1973. Výskumná správa T1594. Pamiatkový úrad SR.

Vallašek 1976 - A. Vallašek: Predbežná správa o archeologickom výskume areálu Spišského hradu v roku 1976. Spišská Kapitula-Pažica. Bratislava 1976. Výskumná správa. Súkromný archív R. Vallaškovej.

Vlk/Sumbalová/Pichová 1979 - K. Vlk/I. Sumbalová/M. Pichová: Levoča. Meštiansky dom, Nám. mieru č. 31. Pamiatkový výskum. Bratislava 1979. Výskumná správa 467/T. KPÚ Prešov, pracovisko Levoča.

Zachar 2013 - J. Zachar: Trenčín-Opatová, poloha „Vel'ká Skalka“. Obnova kláštora na Vel'kej Skalke. Vrútky 2013. Výskumná dokumentácia z archeologického výskumu. KPÚ Trenčín.

Zachar/Horňák 2015 -J. Zachar/M. Horňák: Trenčin-Opatová, poloha "Vel'ká Skalka“. Obnova kláštora na Vel'kej Skalke. Vrútky 2015. Výskumná dokumentácia z archeologického výskumu. KPÚ Trenčín.

Zachar a i. 2014 - J. Zachar/M. Třetinová/V. Kúrová/M. Miscinaiová/T. Račko: Trenčín-Opatová, poloha "Vel'ká Skalka“. Obnova kláštora na Vel'kej Skalke. Vrútky 2014. Výskumná dokumentácia z archeologického výskumu. KPÚ Trenčín.

Mgr. Martin Hanuš, PhD

Slovenské národné múzeum - Archeologické múzeum

Žižkova 12

SK - 81006 Bratislava

martin.hanus@snm.sk

\title{
Luftheizung im Mittelalter in der Slowakei
}

\author{
Martin $\mathrm{H}$ anu š
}

ZUSAMMENFASSUNG

Die Studie bringt neue Kenntnisse über mittelalterliche Luftheizsysteme aus der Slowakei und füllt die Lücken auf der Karte ihrer Distribution (Abb. 20). In der Studie analysieren wir die Funde von den Benediktinerklöstern in Hronský Beňadik (Abb. 4), Košice (Abb. 6), Ludanice (Abb. 11) und Vel'ká Skalka bei Trenčín-Opatová (Abb. 19), weiter aus dem Zisterzienserkloster in Spišský Štiavnik (Abb. 18), Kartäuserkloster in Letanovce-Kláštorisko (zwei Öfen, Abb. 18), den Dominikanerklöstern in Banská Štiavnica (Abb. 1) und Košice (Abb. 5), Franziskanerkloster in Slovenská L’upča (Abb. 15), Prämonstratenserkloster in Leles (Abb. 7) und aus dem Siedlungskomplex in der Nähe von Spišská Kapi- tula (Abb. 16). Zwei Funde kommen aus Bürgerhäusern in Levoča (Abb. 9; 10) und schriftliche Quellen weisen auf die Existenz eines Hypokaustums im Gefängnis in Prešov hin (Abb. 14). Von den Burgen analysieren wir zwei Öfen aus Beckov (Abb. 2; 3), von der kleineren Burg Petuša bei Zvolen (Abb. 13) und ein problematisches Exemplar von Spišský hrad (Abb. 17). Ein Heißluftofen wurde im Herrenhaus des niederen Adels in Nemešany (Abb. 12) entdeckt.

In der Slowakei wurden an 16 Orten insgesamt 20 potenzielle Ofen identifiziert. Über einige Funde können wir aufgrund fehlender genauerer Informationen und ihre umstrittene Natur nur vorsichtig sprechen (Spišský hrad, 
Beckov, Letanovce, Prešov). Elf zuverlässig identifizierte Heißluftöfen werden registriert und in weiteren fünf Fällen sind nur die Bodenplatten mit Luftkanal bekannt (Letanovce, Levoča, Petuša, Slovenská L'upča, Spišský Štiavnik), also insgesamt gibt es aus der Slowakei mindestens 16 zuverlässig identifizierte mittelalterliche Hypokausten-Heizungen.

Heißluftöfen wurden in mehreren Regionen der Slowakei dokumentiert, mit einer Konzentration in der Zips. Umgekehrt zeigt sich in der südwestlichen und nordwestlichen Slowakei deren Abwesenheit. Angesichts des Auftretens von Hypokausten in den umliegenden Ländern kann diese Repräsentationslücke als Folge des Forschungsstandes angesehen werden.

Alle zuverlässig identifizierten Öfen gehören typologisch zu IV. Gruppen (Abb. 21; Steinkammer-Luftheizung) nach der Typologie von K. Bingenheimer (1998). Evolutionär älter als der IV. Typ kommt nur hypothetisch in Betracht im Fall des im 13. Jh. gegründeten Zisterzienserkloster in Spišský Štiavnik, von dem bislang nur die Bodenplatte bekannt ist. Der Bau der meisten Öfen in der Slowakei geht auf das 14. Jh. zurück und spätestens Ende dieses Jahrhunderts ist die Technologie bereits in allen betroffenen sozialen Schichten vorhanden. Der älteste freigelegte Ofen kommt wahrscheinlich aus dem Dominikanerkloster in Banská Štiavnica, datiert etwa vom Ende des 13.-erste Hälfte des 14. Jh. Auf der anderen Seite ist das jüngste zuverlässig datierte Exemplar der Ofen aus dem Dominikanerkloster in Košice, der am Ende des dritten Viertels des 15. Jh. gebaut wurde. Weniger sicher sind die in der Mitte des 16. Jh. gebaute Öfen in Letanovce und in Prešov, welcher nur aus einer schriftlichen Erwähnung im Jahr 1540 bekannt ist. Beide Fälle zeigen sporadisches Überleben der Technologie bis in die Neuzeit.

Von dem Gesichtspunkt des Auftretens von Hypokausten im sozialen Umfeld kann die aus anderen Bereichen bekannte Struktur angegeben werden. Die meisten Befunde stammen aus der klösterlichen Umgebung (elf Fälle), weniger aus den Gebäuden des Adels (fünf Funde) und am wenigsten aus der städtischen Umgebung (drei Fälle). Bei einem Befund von Spišské Podhradie ist die Funktion des Siedlungskomplexes fraglich.

In Klöstern des 14. Jh. war die Hypokausten-Heizung eine Standardausrüstung. Innerhalb des klösterlichen Architekturschemas wurden sie in Refektorien oder in einem Kalefaktorium platziert, welches jedoch in der spätmittelalterlichen Architektur der slowakischen Klöster nicht eindeutig identifiziert werden kann. Das Vorhandensein eines Kalefaktoriums kann theoretisch insbesondere im Zisterzienserkloster in Spišský Štiavnik angenommen werden. In dokumentierten Fällen beträgt die Fläche der beheizten Räume zwischen 52 und $58 \mathrm{~m}^{2}$. Der Fund vom Dominikanerkloster in Košice weicht von diesem Rahmen ab. Hier handelte sich um einen kleineren Raum mit einer Fläche von ca. $25 \mathrm{~m}^{2}$. Es könnte vielleicht um eine Einzelzelle, die sogenannte camera propia gehen. Ein kleinerer Raum ( $\left.29 \mathrm{~m}^{2}\right)$ wurde auch im kleinen Benediktinerkloster Vel'ká Skalka bei Trenčín-Opatová beheizt. Im Kartäuserkloster in Letanovce wurden zwei Hypokausten aufgedeckt, einer heizte das Refektorium, der andere wahrscheinlich den Kapitelsaal.

Außerhalb der klösterlichen Umgebung hatten die erhitzten Objekte vergleichbare Abmessungen. Die kleinste Fläche hatte der Raum im Sitz des niederen Adels in Nemešany $\left(32 \mathrm{~m}^{2}\right)$, die größte in der Adelsburg Beckov $\left(81 \mathrm{~m}^{2}\right)$. Slowakische Beispiele sowie andere Exemplare aus Mitteleuropa zeigen, dass das Hypokaustum in feudalen Siedlungen in der Regel Wohnräume beheizte, manchmal repräsentative Räume, meist im ersten Stock eines Gebäudes. Bei einem Bürgerhaus in Levoča heizte der Ofen den Hauptraum im Erdgeschoss im hinteren Teil des Grundstücks, das wahrscheinlich als Hauptwohnraum oder auch als Büro des Hausbesitzers diente. Gleiche Lösung treffen wir zum Beispiel auch in den Bürgerhäusern am Baltikum.

Es gibt gewisse Variabilität bei den Konstruktionslösungen von Öfen. In Bezug auf das Material erfolgte die Konstruktion in fünf Fällen ausschließlich und überwiegend aus Ziegeln. Die verbleibenden Hypokausten kombinierten hauptsächlich Stein und Ziegel. Bei minimaler Benutzung von Ziegeln wurde es zumindest für die Konstruktion von Gewölbestreifen des Feuerungsrost verwendet. Eine atypische Variante stellt die Anlage aus Banská Štiavnica, die nur aus Stein gebaut wurde, einschließlich des Feuerungsrostes. Die Wahl des Baumaterials scheint je nach geografischer Umgebung zu variieren. Ton wurde als Bindemittel in den Heizkammern verwendet. Das Mörtelbindemittel wurde meist nur in der Hypokausten-Hülle und im Bedienungsraum aufgetragen, die nicht in direkten Kontakt mit dem Feuer kamen.

Die Größe der Öfen variierte in einem relativ großen Bereich, und meistens nehmen ihre Abmessungen mit der Fläche der beheizten Räume zu. Die kleinsten Öfen stammen aus den Klöstern in Hronský Beňadik $\left(1,21 \mathrm{~m}^{2}\right)$ und Košice $\left(1,95 \mathrm{~m}^{2}\right)$, die größten von Burg Beckov $\left(10,5 \mathrm{~m}^{2} ; 11,84 \mathrm{~m}^{2}\right)$. Die Konstruktion der Öfen bestand hauptsächlich aus einfachen Wänden. In Vel'ká Skalka bei Trenčín-Opatová, Beckov und Košice gab es Öfen mit einer doppelten Außen- und Innenschale. Während die Außenschale aus Stein bestand, der mit Mörtel verbunden war, die Innenschale wurde aus Ziegeln die mit Ton verbunden waren gebaut.

Der Eingang zum Ofen war größtenteils durch eine Metalltür verschließbar, die in eine Türumrahmung aus größeren bearbeiteten Steinen eingepasst war. In geringerer Zahl gab es auch Öfen ohne Spuren des Verschlusssystems, welche durch eine einfache Öffnung zugänglich waren.

Die Rauchabsaugung und die damit verbundene Regelung sind aufgrund des schlechten Erhaltungszustands der Öfen die am wenigsten dokumentierte Komponente. Abzüge in den Außenwänden oder Trennwänden der Räume wurden in Košice-Krásna, Beckov und Nemešany dokumentiert. Im Bürgerhaus in Levoča wurde der Rauch durch einen Schornstein entladen.

Die Frischluftversorgung wurde bei allen Exemplaren durch die Vorderwand gesichert, entweder durch den Eingang zum Ofen oder durch eine kleinere Öffnung darüber. Die obere Öffnung ist nur in Hronský Beňadik erhalten. Bei der Interpretation seiner Funktion werden verschiedene Alternativen angeboten: die erste könnte der Zugang zur Heizkammer und Feuerungsrost mit Kieselsteinen sein, die ihre Wiederauffüllung und Reparatur ermöglichten, die zweite könnte zum Entfernen von Rauch verwendet werden, wenn der Ofen nicht einen anderen Abzug oder Schornstein hätte, die letzte Alternative wäre dass durch die Öffnung in der heizungsfase der erhitzte Feuerungsrost mit Kieselsteinen mit frischer Luft versorgt war, wie bereits erwähnt wurde.

Die Verankerung des Feuerungsrostes in den Öfen ging organisch aus den Seitenwänden heraus oder wurde der Feuerungsroste auf einen Absprung gegründet. Eine spezielle Lösung fand sich in Vel'ká Skalka bei Trenčín-Opatová statt, wo die Gewölbestreifen des Feuerungsrost mit einer doppelten Schicht Ziegel verstärkt wurden. 
Die Hypokausten aus Slowakei hatten den Zugang zu den Öfen ungefähr genauso oft vom Inneren des beheizten Gebäudes, sowie von draußen zugänglich. Der Bedienungsraum wurde auf verschiedene Weise gelöst. Wir begegnen eine Variante, bei der es sich nur um eine einfache Grube handelte, die in verschiedene Formen in den Boden gegraben wurde: rund (Ludanice), rechteckig (Banská Štiavnica) oder L-förmig (Spišské Podhradie). Eine anspruchsvollere Lösung war ein Ziegelschacht (Košice, Košice-Krásna). Der Bedienungsraum war wahrscheinlich über eine Leiter erreichbar. Besondere Zugangstreppen zu den Hypokausten sind aus dem Gebiet der Slowakei nicht registriert. Eine andere Möglichkeit war, wenn sich das Ofen im Keller befand, von dem es gewartet wurde (Letanovce, Levoča), oder wenn das erste Stockwerk mit einem Hypokaustum im Erdgeschoss beheizt war (Beckov, Letanovce, Nemešany). Innerhalb des beheizten Raumes befanden sich die Öfen normalerweise in einer Ecke.

Hypokausten wurden von oben mit Platen mit Lüftungsschlitzen bedeckt, die typischerweise in der Bodenhöhe des beheizten Raums lagen. Im Fall von Ludanice und Vel'ká Skalka bei Trenčín-Opatová scheint es, dass die Platten etwas höher herausragen könnten. Diese Lösung wird sicherlich durch ein Exemplar von Leles dargestellt, das relativ hoch über dem Boden hervorstand.

Die Bodenplatten mit Luftkanälen (neun Funde) sind meistens schlecht erhalten und fragmentiert, also können wir Ihre Maße nur in wenigen Fällen genauer charakterisieren. Sie traten sowohl in quadratischer als auch in länglicher Form auf. Die Dicke der Platten lag zwischen 9 und $17 \mathrm{~cm}$, wobei die größten aus Spišský Štiavnik $(97 \times 44 \times 17 \mathrm{~cm})$ und Nemešany $(88 \times 66$ × $9 \mathrm{~cm})$ stammen. Eine Keramikfliese mit einem Luftkanal aus Košice-Krásna unterscheidet sich von den meisten Exemplaren aus Stein. Alle Befunde waren durch ein rundes Loch mit einem Durchmesser zwischen 9 und $14 \mathrm{~cm}$ gekennzeichnet, das mit einer Rinne bordiert war. Aufgrund des fragmentarischen Zustands der Platten kennen wir die Gesamtzahl der Entlüftungsöffnungen nicht. Die zum Schließen der Luftkanäle verwendeten Ventile wurden nicht gefunden. Wir registrieren aus dem Gebiet der Slowakei auch keine Heißluftkanäle, die Wärme weiter vom Ofen verteilen würden.

Abb. 1. Banská Štiavnica, Dominikanerkloster. 1-Grundriss des Klosters aus der Mitte des 18. Jh. mit markiertem Standort des Ofens; 2 - Grundriss des Nordflügels des Klosters, Detail mit dem Ofen (1, 2 nach Hanuliak 1996, Bauphasen nach Autor); 3 - westliches Ende des Nordflügels des Klosters mit dem Ofen; 4 - Bedieungsraum und Eingang zum Ofen; 5, 6- Detail des Ofens mit Feuerungsrost (3-6 nach Hanuliak 1994). Legende: a - Ausgrabungen 1990-1994; b - 1. Phase, 1. Etappe (viertes Viertel des 13.-erste Hälfte des 14. Jh.); c - 1. Phase, 2. Etappe; $\mathrm{d}-1$. Phase, 3. Etappe (das Hypokaustum); e - 3. Phase (zweite Hälfte des 14.-erste Hälfte des 15. Jh.); f - nicht identifiziert; g - Bauphase der Jesuiten (18. Jh.); h - angenommenes Ausmaß des Hypokaustum; i - Bedienungsraum des Ofens; j - das Ofen; k - Sonde 4/06.

Abb. 2. Beckov, Burg, Nordpalast. 1 - Grundriss der Burg mit der Position des Ofens; 2 - Vorder- und Seitenansicht der Ofenöffnung; 3 -ideale Rekonstruktion der Burg mit der Position des Ofens (1, 3 nach Plaček/Bóna 2007); 4 Grundriss des Erdgeschosses des Nordpalastes mit der Position des Ofens (nach Tóthová 1978); 5 - Blick von oben auf den Ofen; 6 - Grundriss des ersten Stockwerks des
Der Prozess der Aufgabe der Heißlufttechnologie begann relativ früh. In Ungarn können seine Anfänge im königlichen Palast in Visegrád verfolgt werden. Ihre Stilllegung erfolgte bereits während des Aufbaus des Komplexes in der Regierungszeit von Ludwig I. von Anjou, ab den 60er Jahren des 14. Jh. Im aristokratischen Umfeld wurde zuletzt Bau eines Heißluftofens auf der Burg Beckov um die Wende vom 14. zum 15. Jh. festgestellt. In dem kirchlichen Bereich stammt das jüngste Exemplar des nach 1500 erbauten Hypokaustum aus dem Kartäuserkloster in Letanovce. Von Anfang des 15. Jh. begann der Kachelofen schnell die Heißlufttechnologie zu ersetzen. Die rasche Neigung zu den Kacheln lag eher am Interesse an ihren neuen ästhetischen und repräsentativen Charakter und wahrscheinlich auch in der Tatsache, dass es einfacher war mit ihnen die höheren Stockwerke von Gebäuden zu heizen. Im Falle der Heißlufttechnologie erfassen wir fast ausschließlich die Erwärmung des Erdgeschosses, bzw. des ersten Stocks der Gebäude.

Insgesamt kann festgestellt werden, dass das Hypokaustum im 14. Jh., welcher das goldene Zeitalter dieser Heizform darstellt, in der Slowakei verbreitet war. Dies wird durch ihre Quantität angezeigt, die mit den umliegenden Ländern vergleichbar ist. Also kann man sagen, dass die Technologie unseres Territoriums erst in der letzten Entwicklungsphase erreicht hatte.

Außer neuen Ausgrabungen können weitere Fortschritte im Wissen die Revision ältere Forschungen, insbesondere aus dem Schloss- und Stadtumfeld, bringen. In Städten sollte die Aufmerksamkeit hauptsächlich auf die gotischen Teile der reichen Bürgerhäuser in ihren Centren gerichtet werden. Ebenso sind neue Funde in Burgen zu erwarten unter Destruktionsfüllungen im Erdgeschoss und in den Kellern gotischer Paläste, besonders aus der Zeit der Anjou Dynastie und der älteren Sigismund Periode.

Ein weiterer wichtiger Wissensschritt wird die technologische Entwicklung in der Neuzeit zu verfolgen. Man kann sagen, dass das Wissen über die Luftheizung in den folgenden Jahrhunderten nie vollständig verloren ging und überlebte, wenn auch nur am Rande und sich zu neuen Konstruktionsformen entwickelte, bis sie im 19. Jh. eine Renaissance erlebte.

Nordpalastes mit der Position des Rauchabzugs $(2,6$ nach Jančušková 1971); 7 -Blick auf die Ecke des Ofens (5, 7 nach Malec 2020). Legende: a - Hälfte des 13. Jh.; b-1388-1414 (Stibor der Ältere); c - Mitte des 15. Jh.

Abb. 3. Beckov, Burg, Westpalast. 1 - Grundriss der Burg mit der Position des Ofens; 2 -ideale Rekonstruktion der Burg mit der Position des Ofens (1, 2 nach Plaček/Bóna 2007); 3-Grundriss des Kellers des Westpalastes und des Ofens; 4 - Blick auf die Nordwand des Ofens; 5 - Blick auf den Ofen im Keller während der Ausgrabungen (3-5 nach Tóthová 1978); 6 - Blick auf den Ofen im Keller, aktueller Zustand. Legende: a - 13. Jh.; b - 14. Jh.; c - erste Drittel des 15. Jh.; d-16. Jh.

Abb. 4. Hronský Beňadik, Benediktinerkloster. 1 - Plan des Klosters mit der Position des Ofens (nach Haviar 2013); 2 - Blick auf den Ofen (nach Habovštiak/Holčík 1975b); 3 - Detail der unteren Zufuhröffnung des Ofens; 4 Grundriss, Quer- und Längsschnitt des Ofens; 5 - Blick auf den oberen Teil des Bedienungsraum beim Freilegen; 6 - Bedienungsraum (3-6 Autor S. Holčík).

Abb. 5. Košice, Dominikanerkloster. 1 - Plan des Klosters mit der Position des Ofens (nach Rusnák/Volovár 2013); 
2 - Fund der Bodenplatte (nach Rusnák 2009); 3 - architektonischer Kontext des Ofens; 4, 5 - Blick auf den Ofeneingang; 6 - Gesamtansicht auf das Hypokaustum; 7 -Seitenansicht auf den Ofen und dem Bedienungsraum (3-5, 7 nach Rusnák 2018); 8 - Bedienungsraum (6, 8 Autor R. Rusnák).

Abb. 6. Košice-Krásna, Benediktinerkloster. 1 - Plan des Klosters mit der markierten Position des Ofens; 2 Gesamtansicht auf das Hypokaustum; 3 - Grundriss und Seitenansicht auf das Hypokaustum; 4 - Detail des Rauchabzuges; 5 -Keramikfragment der Bodenplatte mit Luftkanal (1, 3, 5 nach Polla 1986); 6 - Blick in das Innere des Ofens (2, 4, 6 Autor B. Polla).

Abb. 7. Leles, Prämonstratenserkloster. 1 - Grundriss des Klosters mit markiertem mittelalterlichem Mauerwerk und der ungefähren Position des Ofens (nach Pomfyová 2015); 2 - Blick von oben auf den Ofen; 3 - Blick auf die Seitenwand des Ofens; 4 - Blick auf die Rückwand des Ofens; 5 - Gesamtansicht des Innenhofs des Klosters während der Forschung in den Jahren 2013 und 2014 mit der markierten Position des Ofens (2-5 Autor P. Šimčík).

Abb. 8. Letanovce-Kláštorisko, Kartäuserkloster. 1 - Grundriss des Klosters mit der Position der Öfen; 2 - ideale Rekonstruktion des Klosters mit markierter Lage der beheizten Gebäude (1, 2 nach Slivka/Chalupecký 1995); 3 - das beheizte Gebäude am großen Kreuzgang; 4 - das beheizte Gebäude am kleinen Kreuzgang mit der Position des Ofens; 5-Fragmente von Bodenplatten mit Luftkanal (Autor M. Slivka).

Abb. 9. Levoča, Majstra Pavla Nr. 31, Bürgerhaus. 1 -Grundriss des Untergeschosses des Hauses (nach Vlk/Sumbalovál Pichová 1979); 2 - der Stadtkern mit der Position des Ofens (nach Oriško 2004); 3 - Draufsicht, Querschnitt, Seitenund Vorderansicht des Ofens; 4 - Vorderansicht auf den Ofen; 5 - Seitenansicht auf den Ofen; 6 - Detail des Eingangs zum Ofen; 7 - Rückansicht des Ofens. Legende: a - vor dem zweiten Viertel des 15. Jh.; b - Mitte des 15. Jh.; c-60. Jahre des 16. Jh.; $d$-Neuzeit; E-der Ofen; f-Ziegel; $\mathrm{g}$-originales Steinmauerwerk; $\mathrm{h}$-Sekundärmauerwerk.

Abb. 10. Levoča, Majstra Pavla Nr. 40, Bürgerhaus. 1 - der Stadtkern mit Fundposition der Bodenplatte (nach Oriško 2004); 2 - Grundriss des Erdgeschosses des Hauses mit Fundposition der Bodenplatte (nach Husovská/Urbanová/Kosová 2016); 3 - Fragment der Bodenplatte (Autor M. Stejskal). Legende: $\mathrm{a}-14$. Jh.; $\mathrm{b}-15$. Jh.; c - 16.-17. Jh.; d - zweite Hälfte des 18. Jh.

Abb. 11. Ludanice, Benediktinerkloster. 1 - Grundriss des Klosters mit Hypokaustum; 2 - Blick von oben auf den Ofen; 3 - Grundriss, Längs- und Querschnitt des Hypokaustums und Stratigraphie der Verfüllung des Bedienungsraums; 4 - Detail der Öffnung des Ofens und Boden mit Aschespuren; 5 - Blick auf den Südflügel des Klosters mit dem Ofen im Inneren und dem Bedienungsraum im Außenbereich; 6 - Blick in den Ofen. Legende: a - Ostflügel, 1. Phase; b - Südflügel, 2. Phase, 14. Jh.; c-Mauernegativ.

Abb. 12. Nemešany (Zalužany), Herrenhaus. 1 - Grundriss des Herrenhauses mit der Position des Ofens; 2 - Rekonstruktion des Herrenhauses mit der Position des Ofens; 3-Grundriss des Erdgeschosses des beheizten Gebäudes mit der Position des Ofens; 4 - Zeichnung des Ofens; 5 - Blick ins Raum V mit dem Ofen in der Ecke; 6 - Blick auf die Vorderwand des Ofens; 7 - Detail des Inneres des Ofens (4, 7 nach Polla 1957); 8 - Detail der Öffnung des Ofens (1-3, 5, 6, 8 nach Polla 1962). Legende: a - Phase 1; $\mathrm{b}$ - Phase 2; $\mathrm{c}$ - Phase 3; $\mathrm{d}$ - Phase 4 .

Abb. 13. Petuša, Burg. 1 - Grundriss der Burg mit der Ausgrabungsflächen und identifizierter Architektur; 2 - Rekonstruktion der ersten Phase der Burgentwicklung; 3 - Fragment der Bodenplatte mit Luftkanal (Autor N. Beljak Pažinová); 4 - Ecke eines Mauergebäudes im südwestlichen Teil der Burg (1, 2, 4 nach Styk/Beljak Pažinová 2020).

Abb. 14. Prešov, Caraffa Gefängnis. 1 - Stadtplan mit der Position von Caraffa Gefängnis (nach Urbanová 2003b); 2 - Katasterkarte der Stadt von 1869 mit dem Gebäude von Caraffa Gefängnis; 3 - Ein Ausschnitt aus Caspars Veduta aus dem Jahr 1768; 4 - Blick auf die Fassade des Caraffa Gefängnisses; 5 - Blick auf den Ofen im Westraum; 6 - Grundriss des Erdgeschosses mit der Position des Ofens (2, 3, 5, 6 nach Petranská 2007).

Abb. 15. Slovenská Lupča, Franziskanerkloster. 1-Grundriss des Klosters mit der Lage der Gruft (nach Mosný/Selecká 2006); 2 - Blick auf die Gruftkonstruktion von sekundär benutzten Hypokaustum Bodenplatten (Autor P. Mosný).

Abb. 16. Spišské Podhradie (Spišská Kapitula)-Pažica. 1 - Plan des Siedlungskomplexes mit der Position des Ofens (nach Vallašek 1999); 2 - Grundriss des beheizten Gebäudes und Ofens (Autor D. Tóth); 3 - Fragment der Bodenplatte (nach Stejskal 2009); 4-Blick auf den Eingang zum Ofen nach der Feldskizze; 5, 6 - Ansicht auf das beheizte Objekt mit der markierten Position des Ofens (4-6 Autor A. Vallašek).

Abb. 17. Spišský hrad (Zipser Burg). 1 - Plan der Burg mit der Position des Ofens (nach Plaček/Bóna 2007); 2 - Grundriss des südöstlichen Teils des Burgkerns mit der Position des Ofens (Autoren A. Vallašek und A. Fiala); 3 - Grundriss des nördlichen Teils des Ofens; 4 - Blick auf das südöstliche Teil der Oberen Burg mit markierter Position des Ofens; 5, 6 - Blick auf den Ofeneingang (3, 5, 6 Autor A. Vallašek). Legende: a - vor dem 13. Jh.; b-14. Jh.; c15. Jh.; d - 16. Jh.; e - 17. Jh.

Abb. 18. Spišský Štiavnik, Zisterzienserkloster. 1 - Blick auf die Fläche des heruntergekommenen Klosters; 2 - die Bodenplatte mit Luftkanal; 3 - Plan der Ausgrabungen und erfassten Architektur des Klosters (nach Kopták 2012).

Abb. 19. Trenčín-Opatová (Velká Skalka), Benediktinerkloster. 1 - Grundriss des Westgebäudes des Klosters mit dem Hypokaustum (nach Haviarová/Haviar 2015); 2 - Blick von oben auf dem Ofen; 3 - Grundriss und Ansicht auf das Westliche Klostergebäude nach dem Wiederaufbau der Jesuiten im Jahre 1783, das zweite und dritte Stockwerk des Klosters (nach Várady 1783); 4 - Blick auf dem Ofen und den beheizten Raum; 5, 6 Detail des Feuerungsrostes mit Kieselsteinen (2, 4-6 nach Zachar/Horňák 2015).

Abb. 20. Verbreitung der mittelalterlichen Luftheizungstechnologie im Südosten Mitteleuropas (nach Hanuš 2016, modifiziert)

Abb. 21. Betriebsschema einer Steinkammer Luftheizung des IV. Typs (nach Hawel 1993). Legende: a - die erste Phase, Brennen; $b$ - der offene Schornstein; $c$ - die zweite Phase, Heizung; $d$ - verschlossener Schornstein; e-Feuer gelöscht; $\mathrm{f}$ - frische Luft. 